UNIVERSIDADE DE SÃO PAULO

FACULDADE DE MEDICINA DE RIBEIRÃO PRETO

Gabriela Yamazaki de Campos

Efeito do agonista de TLR2-Pam3CSk4 em estratégia vacinal contra a infecção por Cryptococcus gattii

Ribeirão Preto

2020 
Gabriela Yamazaki de Campos

\section{Efeito do agonista de TLR2-Pam3CSk4 em estratégia vacinal contra a infecção por Cryptococcus gattii}

Dissertação apresentada à Faculdade de Medicina de Ribeirão Preto da Universidade de São Paulo para obtenção do título de Mestre em Ciências.

Área de concentração: Biologia Celular e Molecular

Orientador: Dr. Thiago Aparecido da Silva

Versão corrigida. A versão original encontra-se disponível tanto na Biblioteca da Unidade que aloja o Programa, quanto na Biblioteca Digital de Teses e Dissertações da USP (BDTD).

Ribeirão Preto 
Autorizo a reprodução e divulgação total ou parcial deste trabalho, por qualquer meio convencional ou eletrônico, para fins de estudo e pesquisa, desde que citada a fonte.

De Campos, Gabriela Yamazaki

Efeito do agonista de TLR2-Pam3CSk4 em estratégia vacinal contra a infecção por Cryptococcus gattii. Ribeirão Preto, 2020

129p. : il. ; $30 \mathrm{~cm}$

Dissertação de Mestrado, apresentada à Faculdade de Medicina de Ribeirão Preto/USP. Área de concentração: Biologia Celular e Molecular.

Orientador: da Silva, Thiago Aparecido

1. Cryptococcus gattii. 2. Agonista de TLR2. 3. Vacina. 4. Imunomodulação. 


\section{Gabriela Yamazaki de Campos}

Efeito do agonista de TLR2-Pam3CSk4 em estratégia vacinal contra a infecção por Cryptococcus gattii

Dissertação de Mestrado apresentada à Faculdade de

Medicina de Ribeirão Preto da Universidade de São Paulo para obtenção do título de Mestre em Ciências.

Área de concentração: Biologia Celular e Molecular Orientador: Dr. Thiago Aparecido da Silva

Aprovado em:

1

\section{Banca examinadora}

$\operatorname{Prof}(\mathrm{a}) . \operatorname{Dr}(\mathrm{a})$. Instituição

Julgamento Assinatura

Prof(a). Dr(a) Instituição

Julgamento Assinatura

Prof(a). Dr(a). Instituição

Julgamento Assinatura 
O presente trabalho foi realizado no Laboratório de Imunoquímica e Glicobiologia do Departamento de Biologia Celular e Molecular e Bioagentes Patogênicos da Faculdade de Medicina de Ribeirão Preto da Universidade de São Paulo, com apoio da Coordenação de Aperfeiçoamento de Pessoal de Nível Superior (CAPES) - Código de Financiamento 88882.378760/2019-01. 


\section{AGRADECIMENTOS}

Agradeço especialmente aos meus pais por todo apoio e incentivo dado, tanto em minha trajetória acadêmica quanto em minha vida pessoal. São exemplos de trabalho e dedicação para mim e tenho orgulho de tê-los como meus pais.

A toda minha família por compreenderem minha ausência e por me incentivarem e apoiarem minhas decisões.

Ao meu namorado Cleber, por ter me dado força nos momentos mais difíceis dessa trajetória. Sempre me apoiou e me incentivou em meus sonhos. Agradeço por todo amor e companheirismo.

Ao meu orientador Dr. Thiago Aparecido da Silva, por toda paciência e confiança depositada em mim. Agradeço por todas as oportunidades que me deu, por não medir esforços para estar presente e por ser um profissional exemplar e referência para mim.

Ao Bruno, companheiro inseparável de mestrado e amigo para todos os momentos. Obrigada por todas as conversas e todos os momentos de descontração.

À Patrícia, por todos os ensinamentos e auxílio concedidos, imprescindíveis para a realização e execução desse trabalho. Obrigada por todo o companheirismo e pela amizade.

À Julia e Letícia, alunas de iniciação científica e amigas que auxiliaram em todos os momentos da realização desse trabalho.

À Prof ${ }^{a}$. Dr ${ }^{a}$ Maria Cristina Roque Barreira, Érica, Patrícia, Sandra e a todos os colegas do Laboratório de Imunoquímica e Glicobiologia pelo constante apoio, carinho, disposição e auxílio para a realização deste trabalho, contribuindo direta ou indiretamente nas discussões dos ensaios experimentais.

Aos funcionários do Departamento de Biologia Celular e Molecular por toda a disposição e auxílio.

À Coordenação de Aperfeiçoamento de Pessoal de Nível Superior (CAPES), órgão financiador facilitador da implementação e fechamento do estudo.

Aos examinadores do trabalho pela contribuição no aperfeiçoamento dessa dissertação.

A todos os meus amigos de Ribeirão Preto, Uberaba e Jaboticabal, por serem como uma segunda família para mim e por todos os momentos de descontração. 
RESUMO 
DE CAMPOS, G. Y. Efeito do agonista de TLR2-Pam3CSk4 em estratégia vacinal contra a infecção por Cryptococcus gattii. 2020. 129p. Dissertação (Mestrado) Faculdade de Medicina de Ribeirão Preto, Universidade de São Paulo, Ribeirão Preto, 2020 .

Criptococose é uma relevante infecção fúngica invasiva que afeta indivíduos imunossuprimidos e imunocompetentes quando causada por Cryptococcus gattii. Esse fungo tem a capacidade de escapar da resposta imune inata e adaptativa do hospedeiro, bloqueando a diferenciação de células Th1 e Th17, que são relacionadas com resposta pró-inflamatória benéfica no controle da criptococose. Agonistas de TLR2 são importantes reguladores da resposta imune e têm sido utilizados como adjuvantes em vacinas contra infecções causadas por bactérias ou vírus. Logo, o presente trabalho visou avaliar o efeito imunomodulador do agonista de TLR2 (Pam3CSk4) como adjuvante em estratégia vacinal contra a infecção por $C$. gattii. Inicialmente, avaliamos o efeito imunomodulador de Pam3CSk4 em macrófago alveolar a partir da linhagem AMJ2-C11, e observamos a indução de uma resposta pró-inflamatória em resposta ao Pam3CSk4 que se manteve na presença de leveduras viáveis de $C$. gattii. $\mathrm{O}$ efeito imunomodulador de Pam3CSk4 elevou a atividade fagocítica de AMJ2-C11 frente a C. gattii, entretanto o efeito fungistático de AMJ2-C11 induzido por Pam3CSk4 não reduziu o crescimento de C. gattii. Em outro momento, avaliamos o efeito imunomodulador de Pam3CSk4 associado à imunização com leveduras inativadas de $C$. gattii no controle da criptococose experimental nos modelos murinos BALB/c e C57BL/6. No protocolo A de imunização, os camundongos BALB/c receberam três imunizações (7 dias de intervalo) contendo $1 \times 10^{5}$ leveduras inativadas em associação com $1 \mu \mathrm{g}$ de Pam3CSk4 (Imunizado+P3C4). No período pós-imunização, observamos que as células esplênicas dos animais do grupo Imunizado+P3C4 estavam mais responsivas ao estímulo in vitro, no entanto, a avaliação do perfil da resposta imune no tecido pulmonar demonstrou a prevalência de um ambiente supressor causado pela administração de Pam3CSk4 associado à imunização. Esse achado repercutiu na ausência do controle da infecção por $C$. gattii através do protocolo A de imunização. Dessa forma, partimos para um protocolo B de imunização em que camundongos C57BL/6 receberam três imunizações (14 dias de intervalo) com 2x10 leveduras inativadas associadas com $1 \mu \mathrm{g}$ ou $10 \mu \mathrm{g}$ de Pam3CSk4 (Imunizado+P3C4- 
$1 \mu \mathrm{g}$ ou Imunizado+P3C4-10 $\mu \mathrm{g}$ ), seguido pela infecção com C. gattii após 14 dias da

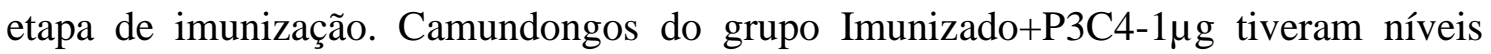
reduzidos de IgG1, IgG2a e IgGA e nenhuma diferença significativa no título de IgG e IgM anti-GXM, comparado ao grupo Imunizado. Ainda sobre o grupo Imunizado+P3C4$1 \mu \mathrm{g}$, observamos níveis elevados de IL-17 e IL-1 $\beta$ no pulmão, mas com ausência do predomínio de células Th17 diferenciadas. Além disso, a redução na expressão relativa de T-bet e aumento de Foxp3 sugerem que os animais do grupo Imunizado+P3C4-1 $\mu \mathrm{g}$ tiveram uma prevalência de células T regulatórias no pulmão, o que não contribuiu no controle da infecção por $C$. gattii. Em relação aos animais imunizados em associação com $10 \mu \mathrm{g}$ de Pam3CSk4 foi detectado altos níveis de IL-17 no tecido pulmonar, no entanto citocinas de diferentes perfis apresentaram níveis reduzidos na ausência de um perfil de células T CD4+ definido. A frequente detecção de IL-17 no tecido pulmonar dos grupos Imunizado+P3C4 não promoveu uma redução da carga de C. gattii no pulmão, fato corroborado pela análise histopatológica que evidenciou maior comprometimento do parênquima pulmonar devido a extensão dos granulomas. Portanto, o efeito imunomodulador de Pam3CSk4, associado com a imunização, favoreceu uma resposta pró-inflamatória que não culminou em atividade efetora, isso se relaciona com um microambiente no tecido pulmonar com um perfil de resposta imune com característica supressora/regulatória induzido após a infecção com C. gattii.

Palavras-chave: Cryptococcus gattii; Agonista de TLR2; Vacina; Imunomodulação 
ABSTRACT 
DE CAMPOS, G. Y. TLR2 agonist-Pam3CSk4 effect in vaccination strategy against Cryptococcus gattii infection. 2020. 129p. Dissertação (Mestrado) - Faculdade de Medicina de Ribeirão Preto, Universidade de São Paulo, Ribeirão Preto, 2020.

Cryptococcosis is a relevant invasive fungal infection that affects immunosuppressed and immunocompetent individuals when caused by Cryptococcus gattii. This fungus can escape the host's innate and adaptive immune response, blocking the differentiation of Th1 and Th17 cells, which are related to a beneficial pro-inflammatory response in the control of cryptococcosis. TLR2 agonists are important regulators of the immune response and have been used as adjuvants in vaccines against infections caused by bacteria or viruses. Therefore, this work aimed to evaluate the immunomodulatory effect of the TLR2 agonist (Pam3CSk4) as an adjuvant in vaccination strategy against $C$. gattii infection. Initially, we evaluated the immunomodulatory effect of Pam3CSk4 in alveolar macrophage cell line AMJ2-C11 and observed the induction of a pro-inflammatory response, caused by Pam3CSk4, which was maintained in the presence of viable C. gattii yeasts. The immunomodulatory effect of Pam3CSk4 increased the phagocytic activity of AMJ2-C11 against $C$. gattii, however the fungistatic effect of AMJ2-C11 induced by Pam3CSk4 did not reduce the growth of $C$. gattii. In another moment, we evaluated the immunomodulatory effect of Pam3CSk4 associated with inactivated yeasts of C. gattii immunization in the control of experimental cryptococcosis in murine models BALB/c and $\mathrm{C} 57 \mathrm{BL} / 6$. In the immunization protocol $\mathrm{A}, \mathrm{BALB} / \mathrm{c}$ mice received three immunizations (7 days apart) containing $1 \times 10^{5}$ inactivated yeasts in association with 1 $\mu \mathrm{g}$ of Pam3CSk4 (Immunized+P3C4). In the post-immunization period, we observed that the splenic cells of the animals of the Immunized+P3C4 group were more responsive to the stimulus in vitro, however, the evaluation of the type of immune response in lung tissue demonstrated the prevalence of a suppressive environment caused by the administration of Pam3CSk4 associated with immunization. This finding reflected in the absence of control of infection by $C$. gattii through the immunization protocol A. Thus, we started an immunization protocol $\mathrm{B}$ in which C57BL/6 mice received three immunizations (14 days apart) with $2 \times 10^{7}$ inactivated yeasts associated with $1 \mu \mathrm{g}$ or 10

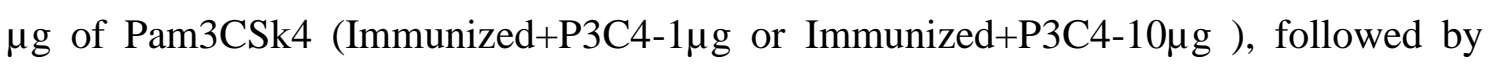
infection with $C$. gattii 14 days after the immunization stage. Mice from the 
Immunized+P3C4-1 $\mu$ g group had reduced levels of $\operatorname{IgG} 1, \operatorname{IgG} 2 \mathrm{a}$ and $\operatorname{IgGA}$ and no significant difference in the IgG and IgM anti-GXM titer, compared to the Immunized group. Still on the Immunized+P3C4-1 $\mu$ g group, we observed high levels of IL-17 and IL-1 $\beta$ in lung tissue but lacking a predominance of differentiated Th17 cells. In addition, the reduction in the relative expression of T-bet and increase in Foxp3 suggest that the animals of the Immunized+P3C4-1 $\mu$ g group had a prevalence of regulatory $\mathrm{T}$ cells in lung tissue, which did not contribute to the control of $C$. gattii infection. Regarding to animals immunized in association with $10 \mu \mathrm{g}$ of Pam3CSk4, high levels of IL-17 were detected in lung tissue, however different types of cytokines showed reduced levels in the absence of a defined $\mathrm{CD} 4^{+} \mathrm{T}$ cell profile. The detection of IL-17 in the lung tissue of the Immunized+P3C4 groups did not promote a reduction in $C$. gattii burden, a fact corroborated by the histopathological analysis that revealed considerable damage of the lung parenchyma due to the extension of the granulomas. Therefore, the immunomodulatory effect of Pam3CSk4, associated with immunization, favored a proinflammatory response that did not culminate in a protective activity, and this is related to a microenvironment in the lung tissue with an immune response profile with a suppressive/regulatory characteristic induced after infection with C. gattii.

Keywords: Cryptococcus gattii; TLR2 agonist; Vaccine; Immunomodulation 


\section{SUMÁRIO}

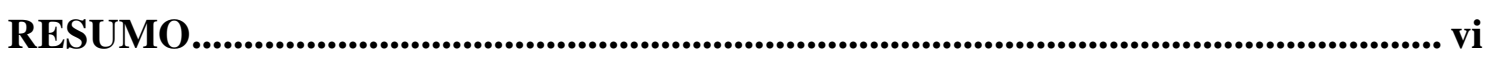

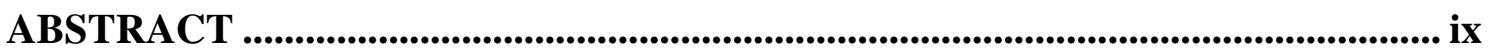

INTRODUÇÃ

1. Considerações gerais sobre as infecções fúngicas invasivas..................................... 17

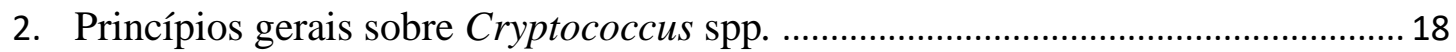

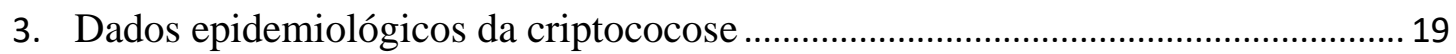

4. Patogênese e os principais fatores de virulência de Cryptococcus spp. .................. 20

5. Papel de receptores de reconhecimento padrão na resposta imunitária do hospedeiro

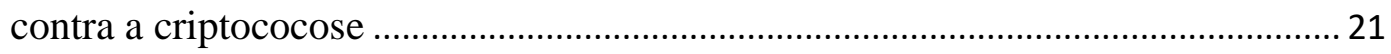

6. Importância de agonistas de TLR2 na imunomodulação.......................................... 25

7. Estratégias imunoterapêuticas contra as infecções fúngicas, com ênfase na

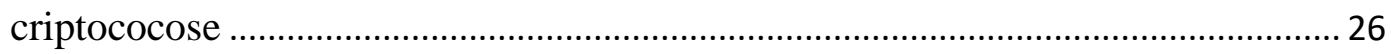

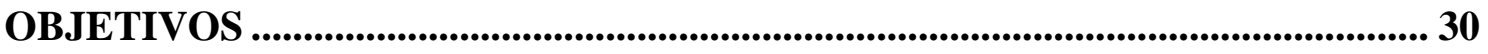

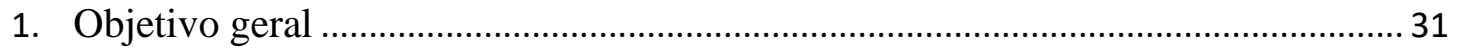

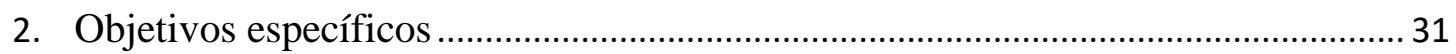

MATERIAIS E MÉTODOS .......................................................................................... 33

1. Linhagem celular AMJ2-C11 e cultivo de Cryptococcus gattii 34

1.1. Análise do nível de expressão de TLR2 em células AMJ2-C11 incubadas com Pam3CSk4

1.2. Quantificação dos níveis de TNF- $\alpha$ produzidos pelos macrófagos alveolares incubados com Pam3CSk4 na presença ou não de $C$. gattii 34

1.3. Análise da expressão relativa de marcadores de polarização M1 e M2 em células AMJ2-C11 incubadas com Pam3CSk4

1.4. Avaliação da atividade fagocítica e fungistática de células AMJ2-C11 estimuladas com Pam3CSk4 sobre $C$. gattii .......................................................... 35

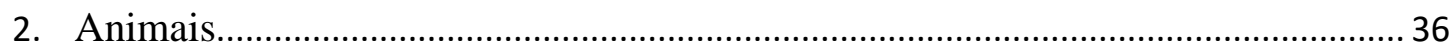




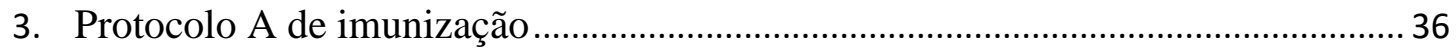

4. Protocolo A de imunização seguido pelo desafio com Cryptococcus gattii ........... 37

5. Protocolo B de imunização e a realização do desafio com Cryptococcus gattii ... 38

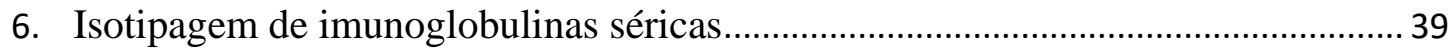

7. Titulação de IgG e IgM sérico total e específico para GXM ................................... 40

8. Quantificação dos níveis de citocinas por ELISA …………….................................. 40

9. Quantificação da produção de TNF- $\alpha$ por células esplênicas obtidas de camundongos submetidos ao protocolo A de imunização, em resposta ao estímulo

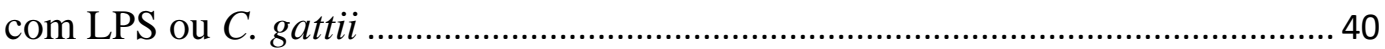

10. Avaliação da carga fúngica pulmonar ........................................................................ 40

11. Fenotipagem dos leucócitos pulmonares por citometria de fluxo ........................... 41

12. Análise do perfil de células $\mathrm{T} \mathrm{CD}^{+}$e subtipos de macrófagos no tecido pulmonar através de qRT-PCR

13. Avaliação histopatológica do pulmão ..................................................................... 42

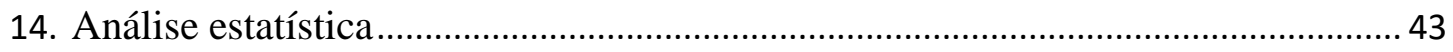

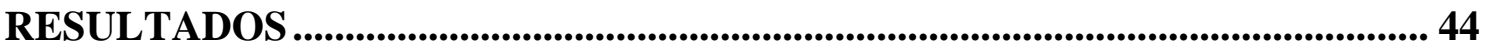

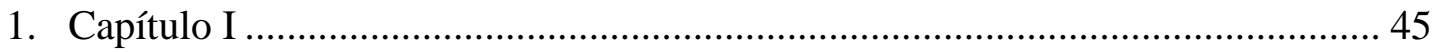

1.1. Nível de expressão do receptor TLR2 em resposta ao estímulo com

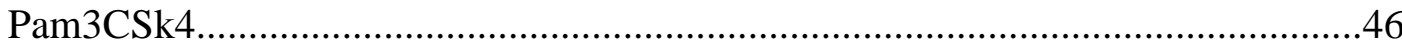

1.2. Perfil de polarização dos macrófagos alveolares AMJ2-C11 induzido por Pam3CSk4.

1.3. Atividade fagocítica e fungistática de macrófagos alveolares AMJ2-C11 estimulados com Pam3CSk4 sobre leveduras de $C$. gattii .................................... 48

1.4. Produção de TNF- $\alpha$ por células AMJ2-C11 incubadas com Pam3CSk4 e cocultivadas $\operatorname{com} C$. gattii 49

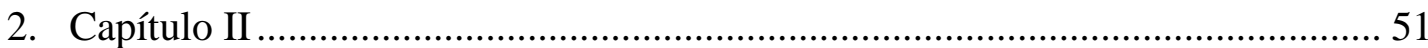

2.1. Avaliação do protocolo de imunização ............................................................ 52

2.1.1. Isotipagem de imunoglobulinas e quantificação de $\operatorname{IgG}$ anti-GXM no soro de camundongos submetidos a estratégia vacinal 
2.1.2. Níveis de citocinas nos tecidos pulmonar e esplênico dos animais submetidos ao protocolo de imunização.

2.1.3. Capacidade responsiva de células esplênicas obtidas de camundongos imunizados em reposta à incubação com $C$. gattii 56

2.2. Avaliação da eficácia do protocolo de imunização no controle da infecção por

C. gattii em camundongos BALB/c 58

2.2.1. Mensuração da carga fúngica pulmonar e análise da sobrevida dos animais submetidos ao protocolo de imunização e infectados com C. gattii 58

3. Capítulo III. 60

3.1. Avaliação da eficácia do protocolo de imunização no controle da infecção por C. gattii em camundongos C57BL/6 61

3.1.1. Quantificação dos níveis séricos de $\operatorname{IgG}$ e $\operatorname{IgM}$ anti-GXM em camundongos submetidos à estratégia vacinal

3.1.2. Isotipagem de imunoglobulinas no soro de camundongos submetidos a estratégia vacinal

3.1.3. Níveis de citocinas no tecido pulmonar e no soro dos animais imunizados, associado com Pam3CSk4, e desafiados com C. gattii.

3.1.4. Fenotipagem dos leucócitos pulmonares de camundongos imunizados, em associação com Pam3CSk4, e infectados com C. gattii 68

3.1.5. Perfil de células $\mathrm{T} \mathrm{CD}^{+}$e subtipos de macrófagos no tecido pulmonar de camundongos imunizados, em associação com Pam3CSk4, e infectados com $C$. gattii.

3.1.6. Carga fúngica pulmonar dos animais submetidos ao protocolo de imunização em associação com Pam3CSk4 e desafiados com C. gattii

3.1.7. Análise histopatológica do pulmão dos animais imunizados, em associação com Pam3CSk4, e infectados com C. gattii 


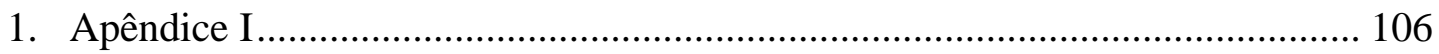

ANEXOS

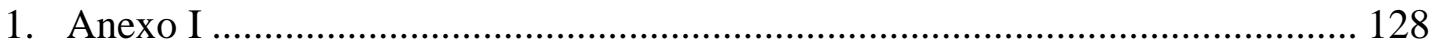


INTRODUÇÃO 


\section{INTRODUÇÃO}

\section{Considerações gerais sobre as infecções fúngicas invasivas}

Há uma estimativa da existência de aproximadamente 1,5 milhão de espécies de fungos distribuídos em uma diversidade de habitats, sendo que 70.000 espécies estão formalmente descritas. Dentre essas, aproximadamente 300 espécies podem causar doença em seres humanos (Hawksworth et al., 2001; Taylor et al., 2001). As infecções fúngicas invasivas oportunistas são a maior causa de morbidade e mortalidade em pacientes imunossuprimidos. A presença de leveduras ou fungos filamentosos em biópsias teciduais ou punção aspirativa, confirmadas após a avaliação histopatológica ou por cultivo das amostras em meios seletivos, define um caso de infecções fúngicas invasivas (IFI) como proposto por Ascioglu et al. (Ascioglu et al., 2002). Além disso, esse grupo também revisou as classificações para IFI importantes a serem utilizadas no contexto clínico e/ou epidemiológico. O fator ambiental está bastante relacionado com o desenvolvimento de infecções fúngicas devido a capacidade de cepas mais virulentas ou resistentes a antifúngicos se disseminarem. Isso causa o aumento do número de indivíduos imunocompetentes com infecções fúngicas invasivas.

A incidência de IFIs tem sido elevada em todo o mundo, com os gêneros Aspergillus spp., Candida spp. e Cryptococcus spp. como os principais causadores das IFIs (Pfaller et al., 2010; Groll et al., 2013). Tem sido observado um aumento de Candida glabrata e Candida auris resistentes a várias drogas, e Aspergillus azol-resistente tem uma prevalência de até 30\% em alguns hospitais europeus, o que aumenta em $90 \%$ a taxa de mortalidade (van Paassen et al., 2016; Stop neglecting fungi et al., 2017). Estudos mostram que as IFIs apresentam elevada morbidade e mortalidade nos Estados Unidos e são responsáveis por mais de 1,6 milhões de mortes (Clark e Drummond, 2019; Papon et al., 2020). O custo anual dessas infecções para o país é de aproximadamente 7,2 bilhões de dólares (Benedict et al., 2018). O gênero Cryptococcus, apresenta importante relevância por acometer não somente indivíduos imunocomprometidos, mas também indivíduos saudáveis, como causado pela espécie Cryptococcus gattii. (O’Halloran et al., 2017; Park et al., 2009). Indivíduos altamente suscetíveis a essas doenças são pacientes que requerem terapia prolongada com imunossupressores, relacionados com transplantes de órgãos, síndrome da imunodeficiência adquirida (AIDS), quimioterapia e uso prolongado de antibióticos. A prevalência de criptococose em pacientes 
imunocomprometidos varia de $2,9 \%$ a $13,3 \%$ e estima-se que a taxa de mortalidade de aspergilose invasiva e candidíase invasiva mundial é de 0,4 mortes por 100.000 pessoas. Porém, esses números aumentam de 60-85\% em pacientes imunossuprimidos (Park et al., 2009; Faria et al., 2010; Reolon et al., 2004). Antes de 1980, década em que houve um grande aumento nos números de pacientes com AIDS, a criptococose era incomum e pouco conhecida. Entretanto, no decorrer dos anos, a incidência da doença aumentou significativamente (Hajjeh et al., 1997).

\section{Princípios gerais sobre Cryptococcus spp.}

O gênero Cryptococcus foi descrito como um patógeno humano em 1894 por Otto Busse. Atualmente, 100 espécies do gênero Cryptococcus são conhecidas, sendo duas delas, Cryptococcus neoformans e Cryptococcus gattii, as principais causadoras da criptococose. Essas variantes do gênero Cryptococcus são categorizadas de acordo com a caracterização bioquímica, ecológica, epidemiológica e aspectos clínicos. A subdivisão em diferentes tipos moleculares e sorotipos se dá pelas diferenças no genótipo molecular: Cryptococcus neoformans com os tipos moleculares VNI/VNII/VNB (C. neoformans var. grubii, sorotipo A), VNIV (C. neoformans var. neoformans, sorotipo D), e VNIII (sorotipo AD); e Cryptococcus gattii com os tipos moleculares VGI, VGII, VGIII e VGIV (sorotipos B e C) (Boekhout et al., 2001; Meyer et al., 2009; Meyer et al., 1993; Farrer et al., 2015; Engelthaler et al., 2014; Billmyre et al., 2014). O tipo molecular de C. gattii mais comumente isolado é VGII, compreendendo $47 \%$ dos achados globais e $64 \%$ dos achados no Brasil (Sharon et al., 2014; Meyer et al., 2003; Trilles et al., 2008; Olivares et al., 2009).

Em relação ao $C$. gattii é normalmente encontrado na forma leveduriforme, com formato esférico ou oval, e possuem parede celular com duplo contorno (Chayakulkeeree et al., 2006). As leveduras são encontradas no meio ambiente, principalmente em regiões tropicais e subtropicais, mas também em áreas de clima temperado e frio (Franzot et al., 1999). As leveduras estão presentes em árvores de eucalipto (Eucalyptus camaldulensis e E. tereticornis) sendo que aproximadamente 50 espécies de árvores possuem um nicho ecológico para $C$. gattii e $C$. neoformans. Também há relatos da presença desse fungo em fezes de aves e em outros sítios ambientais (Pfeiffer et al., 1992; Ellis et al., 2005; Mitchell, et al., 2011). Existem diversas técnicas para a identificação laboratorial das leveduras de Cryptococcus spp., como a microscopia com a utilização de 
tinta da China que destaca a cápsula do fungo em contraste negativo. Além disso, o cultivo de Cryptococcus spp pode ser realizado em meio Sabouraud ou BHI (infuso cérebro e coração) e o aspecto macroscópico é de colônias brilhantes, brancas a castanhas. É possível diferenciar as espécies $C$. gattii e $C$. neoformans utilizando o meio seletivo de Canavanina-glicina-azul de brotimol (CGB). As colônias de C. gattii adquirem uma coloração azul, enquanto as colônias de $C$. neoformans não altera a coloração. Há também métodos imunológicos como o cripto-látex e testes de ELISA que detectam o antígeno de de Cryptococcus spp ou anticorpo específico para fatores de virulência do fungo (Fisher et al., 2001; Mitchell e Perfect, 1995; Casadevall et al., 1998; McMullan et al., 2013; Klein et al., 2009).

\section{Dados epidemiológicos da criptococose}

O maior surto de criptococose causado por C. gattii registrado até o momento aconteceu na ilha de Vancouver, no Canadá, em 1999. Os pacientes eram imunocompetentes, sendo a maioria homens (58\%), 72\% dos pacientes apresentaram lesão pulmonar, $26 \%$ apresentou lesão no sistema nervoso central e a letalidade foi em torno de 10\% (Kidd et al., 2004; Eleni et al., 2010; Stephen et al., 2002; Fyfe et al., 2008). No período de 1999 a 2007 foi detectada uma incidência alarmante da infecção por $C$. gattii nos Estados Unidos da América, com destaque para os estados de Washington e Oregon. Atualmente a criptococose é endêmica no Canadá e costa pacífica dos EUA (MacDougall et al., 2006; Upton et al., 2007).

O estudo de Cryptococcus spp. tem se tornado cada vez mais relevante, pois estima-se um total de 223.100 casos de meningite criptococócica no mundo em pessoas que vivem com HIV em 2014. Desses casos, tem-se 181.100 mortes anuais. A África Subsaariana possui o maior número de casos de criptococose do mundo. Estima-se que a criptococose seja a segunda maior causa de mortes em pacientes com AIDS, estando atrás apenas de tuberculose (Rajasingham et al., 2017). Na América Latina mais de 5000 indivíduos foram afetados pela meningite criptococócica e 2400 mortes ocorrem por ano, sendo que a maior incidência da doença se encontra no Brasil e na Colômbia (Rajasingham et al., 2017). No Brasil, a criptococose é a micose sistêmica com segundo maior número de internações entre 1998 e 2006. Além disso, as regiões norte e nordeste são as mais afetadas pela criptococose causada por C. gattii, com letalidade de $35 \%$ a 
$40 \%$ em adultos jovens de ambos os sexos e crianças (Correa et al., 1999; Consenso em criptococose, 2008).

\section{Patogênese e os principais fatores de virulência de Cryptococcus spp.}

A infecção humana por $C$. gattii se inicia via inalação de leveduras desidratadas ou propágulos que se depositam nos alvéolos pulmonares, desenvolvendo uma infecção pulmonar, que pode ser latente ou desenvolver uma doença aguda. Neste primeiro estágio da infecção, a imunidade inata é de extrema importância com a participação de macrófagos alveolares e células dendríticas que são responsáveis, juntamente com as células epiteliais, pelo reconhecimento inicial das leveduras. Além disso, a forma leveduriforme pode ser opsonizada por anticorpos que favorecem a fagocitose por macrófagos alveolares, nessa situação, Cryptococcus spp. ainda pode sobreviver e replicar no interior do fagolisossomo levando a liberação ao meio extracelular através da via exocitose lítica ou vomocitose. Outro mecanismo de evasão da resposta imunitária do hospedeiro se relaciona com a capacidade do patógeno em adaptar ao estresse no ambiente pulmonar através da expansão do tamanho celular e espessura da cápsula polissacarídica, fatores que comprometem a atividade fagocítica e a atividade fungicida das células da imunidade; além disso, leveduras de tamanhos menores podem ser geradas de maneira a contribuir à disseminação sistêmica do patógeno (O'meara et al., 2012; Gerstein et al., 2015). O conjunto desses fatores permitem que C. gattii e C. neoformans se disseminem para outros órgãos, como a pele, olhos, próstata e sistema nervoso central (SNC) (Perfect et al., 2002; Ruma-Haynes et al., 2000; Sorrel et al., 2001).

Os processos celulares descritos acima são viabilizados no gênero Cryptococcus devido aos diversos fatores de virulência que contemplam $C$. gattii e $C$. neoformans. O principal fator de virulência de $C$. gattii é sua cápsula polissacarídica. Essa cápsula permite a sobrevivência do microrganismo em condições de estresse, como a desidratação e exposição à radiação solar no meio ambiente e na fase inicial da infecção, dificultando sua fagocitose (Tucker e Casadevall, 2002; Coelho et al., 2014). Ela é composta por $90 \%$ a $95 \%$ de glucoronoxilomanana (GXM), 5\% a 8\% de galactoxilomanano (GalXM) e 1\% de manoproteínas (MP) (Cherniak et al., 1995). Estudos demonstraram a capacidade de GXM interferir na função de linfócitos T e na proliferação celular de macrófagos, além de desencadear apoptose (Ben-Abdallah et al., 2012; Coelho et al., 2014). GXMGal pode induzir a desregulação de citocinas e apoptose de linfócitos T. (Eva et al., 2006). Por fím, 
as manoproteínas são proteínas altamente imunogênicas ligadas a glicanas ricas em resíduos de manose, que estão envolvidas na ativação de células $\mathrm{T}$ e na adesão do patógeno em células epiteliais pulmonares (Teixeira et al., 2014). Outros fatores de virulência compreendem a atividade da lacase, a qual é responsável pela produção de melanina, fosfolipase B (Plb1), urease, superóxido dismutase (Sod1) e trealose. A melanina é um pigmento escuro formado pelo fungo a partir de substratos difenólicos e tem a capacidade de conferir resistência fúngica, além de fornecer proteção ao microorganismo, em ambiente natural, contra radiação solar, por absorver a radiação eletromagnética (D. e Arturo, 2003). A Plb1 demonstra capacidade de desestabilizar a membrana de células, provocando lise celular (Ghannoum, 2000; Chrisman et al., 2011) e a urease é capaz de alterar o $\mathrm{pH}$ microambiental, favorecendo a sobrevivência do fungo dentro do fagolisossomo, além de possivelmente ser utilizada para facilitar a invasão de C. neoformans no sistema nervoso central pela barreira hemato-encefálica (Coelho et al., 2014; Morrow et al., 2013; Singh et al., 2013). A Sod1 e trealose atuam como antioxidantes que neutralizam moléculas imunes inatas do hospedeiro, diminuindo o dano oxidativo à célula. (Kwon-Chung e Rhodes, 1986; Ma et al., 2009; Seider et al., 2010; Ma e May, 2009). Pelo fato de C. gattii infectar indivíduos imunocompetentes, ao contrário de $C$. neoformans, provavelmente essas leveduras apresentam fatores de virulência relacionados com essa capacidade (Skolnik et al., 2017).

\section{Papel de receptores de reconhecimento padrão na resposta imunitária do hospedeiro contra a criptococose}

As leveduras ou propágulos desidratados de Cryptococcus spp. inalados pelo hospedeiro se alojam nos alvéolos pulmonares. A barreira pulmonar, que consiste na mucosa pulmonar, células epiteliais e junções intercelulares, é importante em um primeiro momento pois funciona como uma barreira física (Wiesner et al., 2017; Whitsett et al., 2014). A resposta imune inata, composta essencialmente por macrófagos, neutrófilos e células dendríticas pode reconhecer padrões moleculares associados a patógenos (PAMPs) específicos de fungos através de receptores de reconhecimento padrão (PRRs) para fagocitar as leveduras. Assim, o patógeno é internalizado no fagossomo, o que leva à formação do fagolisossomo, ativação de inflamassoma e degradação do mesmo. Entretanto, a diversidade de PAMPs existentes na superfície das 
leveduras de $C$. gattii influencia os níveis de citocinas secretadas por células da imunidade inata (Schoffelen et al., 2013).

As células que compõem a resposta imune inata expressam uma variedade de PRRs, como os receptores do tipo Toll (TLRs), receptores do tipo NOD (NLRs) e lectinas do tipo C (CLRs). Em relação aos receptores TLRs, esses perfazem uma família de proteínas capazes de reconhecerem diversos PAMPs e DAMPs (Janeway et al., 2002). A família de receptores TLR é composta por 10 receptores (TLR1-TLR10) em humanos e 12 (TLR1-TLR9, TLR11-TLR13) em camundongos e são sintetizados no retículo endoplasmático, sofrem modificações pós-traducionais no complexo de Golgi e são recrutados para a membrana celular ou compartimentos intracelulares como endossomos (Botos et al., 2011; Kawasaki et al., 2014). Esses receptores são caracterizados por um domínio extracelular com repetições ricas em leucina, o qual participa do reconhecimento de PAMPs, um domínio transmembrana e o domínio Toll/IL-1 (TIR) em sua cauda citoplasmática, essencial para iniciar a sinalização. O domínio TIR é homólogo ao domínio de sinalização dos receptores para a citocina IL-1 (Botos et al., 2011; O'Neill et al., 2007). Após o reconhecimento de PAMPs ou DAMPs os receptores TLR são dimerizados acarretando a aproximação dos domínios TIR, com isso, proteínas adaptadoras, como MyD88 e TRIF, são recrutadas levando à ativação de diversos fatores

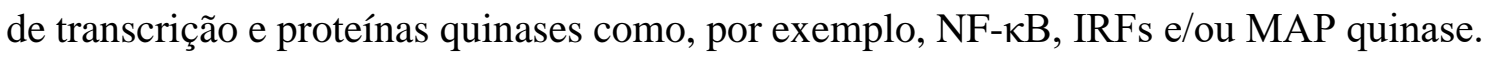
Em resposta a essa cascata de sinalização, ocorre a regulação da expressão de citocinas, quimiocinas e interferon (IFN) do tipo 1 que participam na resposta imune inata e no desenvolvimento de uma resposta imune adaptativa visando a proteção do hospedeiro contra a infecção (Palsson-McDermott et al., 2007).

Os receptores TLR expressos na superfície celular pertencem à subfamília que compreende TLR1, TLR2, TLR4, TLR5, TLR6 e TLR10, enquanto TLR3, TLR7, TLR8, TLR9, TLR11, TLR12 e TLR13 pertencem à subfamília de receptores intracelulares (Kawai e Akira et al., 2010). Em especial, TLR2 forma dímeros com TLR1 ou TLR6 na membrana plasmática e reconhece diversos componentes microbianos como, por exemplo, peptidoglicanos de bactérias gram-positivas (Aderem et al., 2000), zimosan de fungos (Sato et al., 2003), fosfolipomanana de Candida albicans (Jouault et al., 2003) e glicolipídios de Trepanema maltophilum (Opitz et al., 2001). Outro TLR de destaque é o TLR4 que reconhece principalmente lipopolissacarídeos (LPS) de bactérias gramnegativas (Aderem et al., 2000), mas também reconhece GXM (Monari et al., 2005) e galactomanana de Aspergillus fumigatus (Chai et al., 2009). Os receptores TLRs de maior 
relevância no reconhecimento de PAMPs da parede celular de fungos são TLR2 e TLR4 (Patin et al., 2019). Camundongos TLR2\% são mais suscetíveis à infecção sistêmica ou pulmonar por $C$. neoformans, foi observado uma menor sobrevida de animais TLR2\% infectados com $C$. neoformans acompanhado por uma elevada carga fúngica nos órgãos de menor predileção por $C$. neoformans devido à alteração na produção de citocinas efetoras para o controle da disseminação da infecção (Biondo et al., 2005). No entanto, os camundongos TLR2\% não apresentaram um maior comprometimento no tecido pulmonar em decorrência da infecção por C. neoformans (Yaunch et al., 2004). O receptor TLR4 também participa do reconhecimento de Cryptococcus spp. através da interação com GXM de maneira dependente do seu co-receptor CD14, baseado em ensaios in vitro, fato que induziu a produção de NF-kB com ausência da ativação da via de MAPk e secreção de TNF- $\alpha$, indicando um processo incompleto na ativação de TLR4 (Shoham et al., 2001).

A outra família de receptores, denominada CLRs, atuam no reconhecimento de carboidratos como $\beta$-glucanos ou mananas. (Vautier et al., 2012). A função desses receptores é bem conhecida frente a outros patógenos fúngicos, entretanto a capacidade desses receptores mediarem a imunidade frente a $C$. neoformans não está totalmente definida, pois a espessa cápsula polissacarídica pode interferir nessa interação in vivo (Giles et al., 2009; Cross et al., 1995; Thak et al., 2020). O receptor Dectina-1, capaz de reconhecer $\beta$-(1,3)-glucano da parede celular fúngica, é responsável pela fagocitose de $\mathrm{C}$. albicans (Taylor et al., 2007), enquanto Dectina-1 e outros CLRs não são críticos na fagocitose de esporos de C. neoformans (Walsh et al., 2017). Sabe-se que leveduras de C. gattii cultivadas em meio de cultivo YNB expõem em maior quantidade as moléculas de $\beta$-(1,3)-glucano o que favorece consideravelmente a fagocitose por células dendríticas via Dectina-1 (Ueno et al., 2019). Em adição a isso, a opsonização do fungo também é viabilizada por outros mecanismos, como: reconhecimento de $\beta$-(1,6)-glucanos da parede celular fúngica pelo receptor de complemento 3 (CR3) expresso por monócitos/macrófagos, neutrófilos e células natural killer (NK); defensinas e colectinas estão envolvidas na opsonização e indução de resposta inflamatória através de citocinas de perfil Th17 (Polesello et al., 2017; Hajishengallis et al., 2017; Romani, 2011; Borghi et al., 2014).

A partir da atividade funcional de células da imunidade inata após o reconhecimento de leveduras, ocorre um processo de diferenciação celular para conter o estabelecimento da infecção e induzir a montagem de uma resposta imune adaptativa 
efetora no combate da infecção fúngica. Nesse sentido, os macrófagos possuem uma plasticidade que altera seu fenótipo de acordo com o microambiente, sendo caracterizados pelos perfis celulares da via clássica (subtipo M1, de perfil pró-inflamatório) ou pela via alternativa (subtipo M2, de perfil anti-inflamatório) (Mantovani et al., 2004; ShapouriMoghaddam et al., 2018). Os principais estímulos que induzem a polarização M1 são TNF- $\alpha$, IFN- $\gamma$ e LPS. Essas células apresentam como principal marcador molecular a enzima óxido nítrico sintase induzida (iNOS) e produzem altos níveis de citocinas próinflamatórias juntamente com espécies reativas de oxigênio (ROS), fatores que conferem maior atividade microbicida dos macrófagos (Davis et al., 2013; Klar et al., 2018; Zhu et al., 2017). Por outro lado, macrófagos do subtipo M2, tendo como principal marcador a Arginase-1 (Arg-1), são induzidos por estímulo de IL-4 e IL-10 (de Sousa et al., 2019), e esse perfil celular está envolvido na reparação de tecidos e funções regulatórias (Gordon \& Martinez 2010).

Também há o envolvimento de células dendríticas no reconhecimento de leveduras e no desencadeamento da ativação da resposta imune adaptativa (Leopold Wager et al., 2016; Heung, 2017). As células dendríticas, após o processo de maturação, atuam como importantes apresentadoras de antígenos para células $\mathrm{T}$ naive levando a diferenciação desse tipo celular para os perfis Th1, Th2 ou Th17. A caracterização desses perfis se baseia nos fatores de transcrição, como: T-bet, STAT1 e STAT4 envolvidos na diferenciação de células Th1; GATA3 e STAT6 associados ao perfil Th2; ROR- $\gamma$ T e STAT3 na diferenciação de Th17 (Zhu et al., 2010). Células Th1 promovem uma resposta pró-inflamatória, com produção de citocinas como IFN- $\gamma$, interleucina 2 (IL-2) e IL-12. Esse tipo de resposta é bastante associado à proteção contra a criptococose. Por outro lado, a ativação de células Th2 promove uma resposta anti-inflamatória, associada com a produção de citocinas como IL-4, IL-5 e IL-13. Esse tipo de resposta não é protetor para a criptococose. Já as células Th17, quando ativadas, produzem IL-6, IL-17A, IL-21, IL22 e TGF- $\beta$ (Campuzano e Wormley, 2018). Células T CD4 ${ }^{+} / \mathrm{Foxp}^{+}$, que são as células T reguladoras (Treg), produzem IL-10 e TGF- $\beta$ para suprimir níveis elevados da resposta inflamatória (Iannitti et al., 2012). Como já abordado anteriormente, C. gattii é capaz de infectar indivíduos imunocompetentes, o que exige processos adicionais para subverter a atenuação de células da imunidade inata e adaptativa do hospedeiro (Gibson et al., 2015). Essas leveduras conseguem atenuar a função de células dendríticas pulmonares, uma vez que sua maturação é comprometida pelo bloqueio da liberação de TNF- $\alpha$ e quimiocinas (Angkasekwinai et al., 2014; Huston et al., 2013). 


\section{Importância de agonistas de TLR2 na imunomodulação}

O receptor TLR2 é uma glicoproteína transmembrana do tipo I que apresenta um domínio citoplasmático TIR responsável por recrutar os adaptadores MyD88 e TIRAP

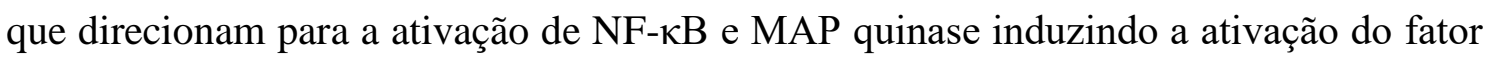
de transcrição AP-1 (Kumar et al., 2009). Na membrana celular, TLR2 forma heterodímeros com TLR1 ou TLR6, sendo que na presença do ligante não há sinalização devido à ausência de interação entre os domínios intracelulares (Jin et al., 2007; Kang et al., 2009). Na presença do ligante, a ativação de ambos os tipos de heterodímeros, TLR2/TLR1 e TLR2/TLR6, resultam na mesma cascata de sinalização (Farhat et al., 2008). A expressão de TLR2 tem sido relatada em células endoteliais, epiteliais, apresentadoras de antígenos (APCs) e o efeito imunomodulador via TLR2 foi verificado em células $\mathrm{B}, \mathrm{T}, \gamma \delta \mathrm{T}, \mathrm{NK}$, neutrófilos, macrófagos, entre outras células do sistema imune (Flo et al., 2001; Brzezińska-Błaszczyk e Wierzbicki., 2010; Duthie et al., 2011; De Campos et al., in press).

$\mathrm{O}$ receptor TLR2 reconhece uma ampla diversidade de moléculas devido à formação de heterodímeros, reconhecendo os principais componentes naturais como lipoproteínas, peptidoglicanos (PGN), ácido lipoteicoico (LTA) e zimosan (Kumar et al., 2009; Hirschfeld et al., 2001), sendo que o dímero TLR2/1 reconhece majoritariamente lipopeptídeos triacetilados e TLR2/6 lipopeptídeos diacetilados (Schenk et al., 2009). Ligantes sintéticos são amplamente utilizados em ensaios de imunomodulação por TLR2 como lipopeptídeo di-palmitoil S-glicerol cisteína (Pam2CSK4), lipopeptídeo tripalmitoil S-glicerol cisteína (Pam3CSK4) e Pam2CGDPKHPKSF (FSL-1) (Shibata et al., 2000; Brandt et al., 2013). A partir da ativação do receptor, os compostos imunogênicos são capazes de promoverem uma atividade imunomodulatória a partir de diversos fatores. Os ligantes de TLR2 reduzem transientemente a motilidade de APCs no sítio inflamatório favorecendo a internalização do antígeno e, em seguida, há uma upregulação de CCR7 que possibilita a migração de APCs para as áreas de localização das células T (Lee et al., 2011; McKimmie et al., 2009). A ativação via TLR2 contribui no controle de maturação de fagossomos permitindo uma melhor associação do antígeno ao complexo principal de histocompatibilidade II (MHC-II), levando ao aumento da expressão desse complexo na superfície celular. Além disso, a apresentação por DCs de epítopos via MHC-II para células T específicas foi aumentada na presença do agonista de TLR2 Pam3CSK4 (Khan et al., 2007). Por isso, alguns protocolos de imunização utilizam 
a associação covalente do antígeno ao agonista para intensificar a resposta imune celular e humoral (Cote-Sierra et al., 2002; Khan et al., 2007; Zeng et al., 2002). ThomaUszynski et al. desmonstrou que a presença do agonista Pam3CSK4 induz resposta Th1 através da ativação de APCs, com células T produzindo altos níveis de IL-12 (ThomaUszynski et al., 2000). Isso foi demonstrado in vivo por Chua et al. através de um modelo vacinal contra o vírus da hepatite $\mathrm{C}$, o que pode levar ao aumento da sobrevida e taxa de proliferação celular com perfil Th1 (Chua et al., 2008). A ativação de TLR2 leva à indução da apresentação-cruzada (cross-presentation) de antígenos em células DC devido ao aumento da internalização do antígeno e entrega do mesmo para o citosol após a ativação celular pelo agonista BPPCysMPEG, fato que promove um aumento na resposta citotóxica das células $\mathrm{T} \mathrm{CD}^{+}$(Prajeeth et al., 2010). Além disso, Komegae et al. demonstrou que a via de ativação de TRL2, com sinalização por MyD88, favorece a produção de anticorpos de forma dependente de células $\mathrm{T}$ e favorece a longevidade das células B produtoras de anticorpos (Komegae et al., 2013). A combinação dos agonistas Pam3CSK4 e Poly I:C (agonista de TLR3) aumenta a ativação de células B in vitro e aumenta a produção de anticorpos em modelo de vacinação in vivo (Weir et al., 2017). Outra estratégia vacinal utilizando Pam3CSK4 é o de Salgado et al. contra a leishmaniose visceral, a qual demonstrou um aumento na imunomodulação, porém não houve resposta imune protetora (Salgado et al., 2019). Até o momento, não há estudos abordando o uso de agonistas de TLR2 como adjuvantes em estratégias vacinais contra infecções fúngicas. Portanto, fatores oriundos da estimulação celular via TLR2 contribuem fortemente no desenvolvimento de uma estratégia de imunização eficaz, tendo o agonista de TLR2 como um importante adjuvante nesse processo.

\section{Estratégias imunoterapêuticas contra as infecções fúngicas, com ênfase na criptococose}

Atualmente, novos conceitos e avanços científicos e tecnológicos na vacinologia tem aumentado significativamente, com grande foco em doenças virais e bacterianas, porém esse mesmo progresso tem sido lento em relação às infecções fúngicas invasivas. Existem vários desafios no desenvolvimento de uma vacina eficaz contra infecções fúngicas, como as diferenças dos mecanismos de escape do sistema imune entre as espécies e a variedade de pacientes, que podem ser imunocomprometidos ou imunocompetentes com constante exposição fúngica em áreas endêmicas, necessitando 
de uma imunomodulação favorável de longa duração (Cassone, 2008; Edwards, 2012; Iannitti et al., 2012). A ativação da resposta imune pode ser aparentemente paradoxal, uma vez que a resposta antifúngica pode induzir resistência e/ou tolerância do hospedeiro, e uma estratégia vacinal eficaz deve considerar a ampla variabilidade de interações patógeno-hospedeiro (Romani et al., 2011; Innitti et al., 2012). Os principais medicamentos utilizados no tratamento da criptococose são a anfotericina B (AmB), 5flucitosina (5-FC) e fluconazol (FLZ). Os três medicamentos são utilizados na terapia da meningite criptococócica ou criptococose pulmonar severa, sendo que o uso de AmB é combinado com 5-FC, e o paciente frequentemente necessita continuar o tratamento com FLZ por meses (Lortholary, 2007; Perfect et al., 2010; Sabiiti e May, 2012). O tratamento consiste em três fases: indução (2 semanas), consolidação ( 8 semanas) e manutenção (6 a 12 meses). O uso de eficientes drogas fungicidas no período de indução é crucial, entretanto, o acesso a esse tratamento é ainda inadequado mundialmente (Perfect et al., 2010; Perfect e Bicanic, 2015). Além disso, as drogas antifúngicas podem ser limitadas pelo espectro de atividade, toxicidade, indução de resistência, e capacidade limitada de eliminar o patógeno dos órgãos afetados (Hamad, 2008; Sloan et al., 2008). Dessa forma, o desenvolvimento de novos agentes terapêuticos e estratégias profiláticas contra infecções fúngicas é almejado (Datta e Hamad, 2015). Dentre as novas estratégias no controle de infecções fúngicas, destacam-se os agentes imunomoduladores (Anthachopoulos e Walsh, 2012), a seguir abordados.

Diversos estudos relatam o efeito protetor da administração de citocina IL-12 na criptococose experimental, resultando em redução da carga e da disseminação fúngica e proporcionando maior sobrevida ao indivíduo infectado (Kawakami et al., 1996; Hardison et al., 2012). O tratamento com IL-12 promove a estimulação de células NK e linfócitos T, seguindo-se a produção de IFN- $\gamma$. Dessa maneira, a imunomodulação da imunidade age sinergicamente com a terapia medicamentosa (FCZ) para a eliminação do fungo (Clemons et al., 2001; Clemons et al., 1994). Há autores que defendem a inclusão de IFN- $\gamma$ na terapia contra a criptococose, já que pacientes com meningite criptococócica tratados com AMB, 5-FC e IFN- $\gamma$ reduziram drasticamente a carga fúngica no fluido cerebroespinal, quando comparados a pacientes para os quais não se associou IFN- $\gamma$ ao tratamento (Jarvis et al., 2012). Além disso, há um relato de que o tratamento com TNF$\alpha$ de camundongos experimentalmente infectados com $C$. neoformans promoveu redução da carga fúngica pulmonar, aumento dos níveis de IFN- $\gamma$ e maior infiltrado de macrófagos e neutrófilos (Milam et al., 2007). Outra estratégia imunomoduladora consiste na 
administração de IL-23 para expandir as células Th17; ela resultou em maior sobrevida de animais infectados com C. neoformans (Kleinschek et al., 2010).

Vacinas com agentes fúngicos atenuados ou mortos mostram ser boas candidatas na imunomodulação e resposta imune de longo termo, que podem ser eficientes em pacientes imunocompetentes. A vacinação subcutânea com leveduras heat-killed de Saccharomyces cerevisiae protegeu camundongos contra diferentes infecções, como as causadas por Coccidioides posadasii, Candida albicans e Aspergillus fumigatus (Capilla et al., 2009; Liu et al., 2011; Liu et al., 2012). Cepas mutantes atenuadas de C. albicans e o uso da parede celular em modelos murinos têm se mostrado como estratégias eficientes, porém ainda não foram testadas em humanos (Saville et al., 2009; Edwards, 2012; Cassone, 2014). Além disso, vacinas utilizando material genético de fungos causadores da coccidioidomicose, paracoccidioidomicose e pneumocistose tem sido considerado em estratégias de imunização devido à indução de resposta imune celular (Pinto et al., 2000; Ivey et al., 2003; Zheng et al., 2005). A conjugação do alume (NDV3) com glicoproteínas Als3p como forma de vacinação demonstrou importante proteção contra a infecção por C. albicans, além de outros achados que mostraram proteção cruzada contra a bactéria Staphylococcus aureus (Spellberg et al., 2006; Phan et al., 2007; Schmidt et al., 2012). Essa vacina demonstrou ser segura e protetora em humanos, levando à produção de células T específicas e aumento da produção de IFN- $\gamma$ e IL-17 (Ibrahim et al., 2013; Santos e Levitz, 2014). Outra estratégia imunoterápica contra a infecção por C. albicans foi o uso de anticorpos monoclonais que interagem com a proteína Als3p, sendo um forte candidato na aplicação clínica devido à maior proteção de camundongos infectados (Sevilla et al., 2006; Torosantucci et al., 2009; Boniche et al., 2020).

Há importantes estudos que demonstraram a eficácia da estratégia de vacinação contra a criptococose através de diferentes protocolos de imunização. A utilização de adjuvantes, como a solução completa de Freund (CFA), associada com o antígeno filtrado de cultura de $C$. neoformans $(\mathrm{CneF})$ foi capaz de proteger parcialmente contra a infecção por C. neoformans (Murphy et al., 1998). Em outros estudos, os animais foram vacinados com proteínas da parede celular de C. gattii associadas às proteínas da cápsula do fungo, em outro caso optou-se pela transferência adotiva de DC pulsadas com uma cepa acapsular de $C$. gattii ( $\triangle \mathrm{CAP} 60)$, em ambos os estudos houve uma redução significativa da carga fúngica pulmonar (Ueno et al., 2015; Chaturvedi et al., 2014; Specht et al., 2015). O desencadeamento da produção das citocinas TNF- $\alpha$, IFN- $\gamma$ e IL-17 mostrou-se 
essencial para que a estratégia testada conferisse proteção contra a infecção por $C$. gattii (Ueno et al., 2015; Chaturvedi et al., 2014; Specht et al., 2015). Mais recentemente, partículas de glucano (GP) carreando as proteínas recombinantes Cda1 e Cda2 de $C$. neoformans foram utilizadas como ferramenta de vacinação de camundongos C57BL/6, resultando no prolongamento da sobrevida e redução da carga fúngica dos animais imunizados e desafiados com C. neofomans ou C. gattii (Specht et al., 2017). No estudo de Specht (2017) ficou evidente que a associação de componentes do patógeno com agonista de Dectina-1 repercutiu em um maior controle da infecção e prolongou consideravelmente a sobrevida dos animais infectados (Specht et al., 2017).

Os aspectos aqui sumarizados atestam a validade das tentativas de associar a terapia antifúngica convencional à administração de agentes que direcionem a imunidade para um perfil predominantemente Th1. Nesse contexto, agonistas de TLRs proporcionam novas abordagens com potencial profilático e terapêutico de combate às doenças infecciosas, por ativarem mecanismos da imunidade inata que, por si, já contribuem para a eliminação do patógeno, como também por direcionarem a resposta adaptativa para um padrão protetor (Mifsud et al., 2014). No contexto da infecção por $C$. neoformans, essa estratégia é suportada pelo fato de diferentes agonistas de TLRs exercerem atividades sobre células microgliais, resultando em aumento da taxa de fagocitose e da capacidade de induzir o killing do fungo. Essa modulação da resposta de micróglia foi estimulada por agonistas de TLR2, TLR3 e TLR4. Assim, é válido considerar que agonistas de TLRs tenham potencial terapêutico e possam favorecer a resolução da infecção causada pelo C. neoformans (Redlich et al., 2013). Essa estratégia pode ser expandida ao combate da infecção por C. gattii, já que TLR4 e TLR9 estão envolvidos no reconhecimento de PAMPs desse fungo e dirigem o padrão de citocinas produzidas por células da imunidade inata (Schoffelen et al., 2013). 
OBJETIVOS 


\section{OBJETIVOS}

\section{Objetivo geral}

Avaliar o efeito do agonista de TLR2-Pam3CSk4 como adjuvante em uma estratégia vacinal contra a infecção por $C$. gattii.

\section{Objetivos específicos}

1) Avaliar o efeito in vitro de Pam3CSk4 na linhagem de macrófago alveolar AMJ2C11, a partir dos seguintes parâmetros:

a. Mensurar o nível de expressão do receptor TLR2 na superfície celular;

b. Quantificar os níveis de TNF- $\alpha$ no sobrenadante de células estimuladas;

c. Quantificar a expressão relativa de marcadores moleculares associados à polarização de macrófagos;

d. Avaliar em macrófagos alveolares estimulados com Pam3CSk4 sua atividade fagocítica e fungistática sobre leveduras de C. gattii;

e. Quantificar níveis de TNF- $\alpha$ no sobrenadante de AMJ2-C11 incubadas com Pam3CSk4 e co-cultivadas com $C$. gattii.

2) Protocolo A de imunização

Realizado o protocolo de imunização em animais BALB/c, o efeito da vacinação nos períodos pós-imunização foi avaliado a partir dos seguintes parâmetros:

a. Isotipagem de imunoglobulinas séricas;

b. Mensuração do título de anticorpo IgG específico para GXM no soro;

c. Quantificação dos níveis de citocinas pró e anti-inflamatórias no baço e pulmão;

d. Análise da capacidade responsiva de células esplênicas oriundas de animais imunizados em resposta à infecção in vitro $\operatorname{com}$ C. gattii. 
Realizado o protocolo de imunização em animais BALB/c, a eficácia da vacinação no controle da criptococose após o desafio dos animais com $C$. gattii foi avaliado a partir dos seguintes parâmetros:

a. Avaliação da carga fúngica pulmonar por $\mathrm{CFU}$;

b. Análise da sobrevida dos animais.

3) Protocolo B de imunização

Realizado o protocolo de imunização em animais C57BL/6, a eficácia da vacinação no controle da criptococose após o desafio dos animais com C. gattii foi avaliado a partir dos seguintes parâmetros:

a. Mensurar no soro o título de anticorpos IgG e IgM específicos para GXM;

b. Isotipagem de imunoglobulinas séricas;

c. Quantificar os níveis de citocinas pró e anti-inflamatórias no pulmão e soro;

d. Fenotipar os tipos celulares na suspensão de leucócitos pulmonares por citometria de fluxo;

e. Avaliar no tecido pulmonar a expressão relativa de marcadores moleculares associados às seguintes condições: perfil de polarização dos macrófagos e perfil de diferenciação de células T CD4+;

f. Avaliação da carga fúngica pulmonar por $\mathrm{CFU}$;

a. Avaliação histopatológica do pulmão. 
MATERIAIS E MÉTODOS 


\section{MATERIAIS E MÉTODOS}

\section{Linhagem celular AMJ2-C11 e cultivo de Cryptococcus gattii}

A linhagem de macrófagos alveolares AMJ2-C11 foi obtida do Banco de Células do Rio de Janeiro (BCRJ) e mantida em meio DMEM high glucose (GE Healthcare; Chicago, Illinois, USA) suplementado com soro fetal bovino (10\%), L-glutamina (4 mM), piruvato de sódio $(1 \mathrm{mM})$ e antibiótico (1\%), e incubada em estufa de $\mathrm{CO}_{2}(5 \%)$ a $37^{\circ} \mathrm{C}$.

Foi utilizada a linhagem de $C$. gattii R265 sorotipo B, tipo molecular VGII, a qual foi cultivada em ágar Sabouraud dextrose a $30^{\circ} \mathrm{C}$ com agitação contínua de $190 \mathrm{rpm}$, por 18-24 horas. Após, as leveduras foram centrifugadas, lavadas com PBS e quantificadas em china ink, para assim realizar a infecção in vitro, in vivo ou a etapa de inativação das leveduras para a imunização dos animais.

\subsection{Análise do nível de expressão de TLR2 em células AMJ2-C11 incubadas com Pam3CSk4}

Células AMJ2-C11 na concentração de $1 \times 10^{5}$ células $/ \mathrm{mL}$ foram incubadas somente com meio de cultivo ou com $1 \mu \mathrm{g} / \mathrm{mL}$ de Pam3CSk4 (catalog code: tlrl-pms; San Diego, CA, USA) por 16 horas. As células foram desaderidas e a suspensão celular foi marcada com 2,5 $\mu \mathrm{g} / \mathrm{mL}$ de anti-TLR2-PE (clone 6C2). Nessa etapa, a incubação foi feita por 45 minutos e, em seguida, as células foram lavadas duas vezes com PBS e fixadas com PBS-formaldeído (1\%). Após essas etapas, foi realizada a análise por citometria de fluxo (Guava EasyCyteTM Mini System).

\subsection{Quantificação dos níveis de TNF- $\alpha$ produzidos pelos macrófagos alveolares incubados com Pam3CSk4 na presença ou não de $C$. gattii}

Células AMJ2-C11 na concentração de $1 \times 10^{4}$ céls $/ \mathrm{mL}$ foram estimuladas com IL4 (40 ng/mL), P3C4 (1 $\mu \mathrm{g} / \mathrm{mL})$, PMA $(50 \mathrm{ng} / \mathrm{mL})+$ Ionomicina $(1 \mu \mathrm{M})$ ou somente meio de cultivo. Após 24 h de incubação, o sobrenadante da cultura celular foi coletado. No co-cultivo com $C$. gattii, as células foram incubadas nessas mesmas condições, porém a adição das leveduras foi simultânea à adição dos estímulos, sendo utilizado a razão 1:1 (leveduras:macrófagos). Para quantificar os níveis de TNF- $\alpha$ no sobrenadante da cultura 
celular foi realizado o ensaio imunoenzimático (ELISA) com o kit BD Biosciences (San Diego, CA, USA), conforme descrito pelo fabricante. O valor de absorbância foi determinado em $450 \mathrm{~nm}$ em espectrofotômetro para microplacas (PowerWave X; BioTek Instruments, Inc.).

\subsection{Análise da expressão relativa de marcadores de polarização M1 e M2 em células AMJ2-C11 incubadas com Pam3CSk4}

Para quantificar a expressão relativa dos transcritos iNOS, Arginase-1 e IL-23 através de qRT-PCR, células AMJ2-C11 na concentração de $7 \times 10^{5}$ células/mL foram incubadas com IL-4 (40 ng/mL) ou Pam3CSk4 (1 $\mu \mathrm{g} / \mathrm{mL})$. Após 24 h de incubação, o RNA foi extraído utilizando o reagente TRIzol (Life Technologies, Carlsbad, CA, USA) conforme descrito pelo fabricante. O RNA total foi utilizado para conversão em cDNA utilizando o kit iScript ${ }^{\mathrm{TM}}$ cDNA Synthesis (Bio-Rad). A reação de qRT-PCR foi realizada em um volume final de $10 \mathrm{uL}$ utilizando EvaGreen (Bio-Rad). Para a leitura do qRT-PCR foi utilizado o equipamento CFX96 (Bio-Rad) considerando as seguintes condições de reação: $95^{\circ} \mathrm{C}$ por $30 \mathrm{seg}, 40$ ciclos de $95^{\circ}$ por $05 \mathrm{seg} / 60^{\circ} \mathrm{C}$ por $5 \mathrm{seg}, 91,5^{\circ} \mathrm{C}-95^{\circ} \mathrm{C}$ por 5 seg. A expressão relativa do transcrito foi quantificada usando o método $\Delta \Delta \mathrm{Ct} \mathrm{e}$ normalizado para a expressão de $\beta$-actina. Os primers utilizados para a reação de PCR foram: $\quad \beta$-actina (F: 5'-CCTAAGGCCAACCGTGAAAA-3' / R: 5'GAGGCATACAGGGACAGCACA-3'), Arginase-1 (F: 5'GTTCCCAGATGTACCAGGATTC-3' / R: 5'-CGATGTCTTTGGCAGATATGC-3'),

iNOS2 (F: 5'-CCGAAGCAAACATCACATTCA-3' / R: 5'GGTCTAAAGGCTCCGGGCT-3') e IL-23 (F: 5'-TCCGTTCCAAGATCCTTCGA-3' / R: 5'-TGTTGGCACTAAGGGCTCAG-3').

\subsection{Avaliação da atividade fagocítica e fungistática de células AMJ2-C11 estimuladas com Pam3CSk4 sobre $C$. gattii}

Na avaliação da atividade fagocítica, células AMJ2-C11 na concentração de $1 \times 10^{4}$ células/mL foram semeadas em placas de 24 poços e incubadas por $4 \mathrm{~h}$. Em seguida, as células foram estimuladas com IL-4 (40 ng/mL), IFN- $\gamma(40 \mathrm{ng} / \mathrm{mL})$, P3C4 (1 $\mu \mathrm{g} / \mathrm{mL})$ ou somente meio de cultivo (Meio). Após 24 h de incubação, as células AMJ2-C11 foram infectadas com $1 \times 10^{5}$ leveduras por $5 \mathrm{~h}$. Então, os poços foram lavados duas vezes com 
PBS para remover leveduras não-aderentes e as células AMJ2-C11 foram lisadas com água estéril. Essa suspensão foi semeada em ágar Sabouraud dextrose para quantificar as unidades formadoras de colônias (CFU), representando a atividade fagocítica.

$\mathrm{Na}$ avaliação da atividade fungistática, células AMJ2-C11 na concentração de $1 \times 10^{4}$ células $/ \mathrm{mL}$ foram semeadas em placas de 24 poços e incubadas por $4 \mathrm{~h}$. As células foram estimuladas com IL-4 (40 ng/mL), IFN- $\gamma(40 \mathrm{ng} / \mathrm{mL})$, P3C4 $(1 \mu \mathrm{g} / \mathrm{mL})$ ou somente meio de cultivo (Meio), e simultaneamente infectadas com $1 \times 10^{3}$ leveduras $/ \mathrm{mL}$. Após 24 $\mathrm{h}$ de incubação, os macrófagos foram desaderidos, lisados e homogeneizados ao sobrenadante. Essa suspensão foi semeada em ágar Sabouraud dextrose para determinar o CFU, representando a atividade fungistática.

\section{Animais}

Foram utilizados camundongos da linhagem BALB/c e C57BL/6, machos, entre 6 e 8 semanas de idade, provenientes do biotério de criação de animais isogênicos da Faculdade de Medicina de Ribeirão Preto (FMRP-USP). Os animais foram utilizados na padronização dos protocolos de imunização e na avaliação desses protocolos após infecção com C. gattii. Os ensaios realizados com os animais estão de acordo com os princípios propostos pela Comissão de Ética no Uso de Animais - CEUA. O projeto foi aprovado pelo comitê de ética da FMRP-USP sob o número de protocolo 072/2019 e encontra-se em anexo.

\section{Protocolo A de imunização}

Foram utilizados 15 camundongos BALB/c em cada replicata experimental sendo divididos igualmente em 3 grupos: PBS (grupo controle), Imunizado (imunizados apenas com leveduras inativadas de $C$. gattii) e Imunizado+P3C4 (imunizados com leveduras inativadas de $C$. gattii associadas com Pam3CSk4). Os camundongos BALB/c foram anestesiados com cloridrato de quetamina $(80,0 \mathrm{mg} / \mathrm{Kg})$ e cloridrato de xilazina (7 $\mathrm{mg} / \mathrm{Kg}$ ) via intraperitoneal (i.p.) e imunizados via intranasal (i.n., $20 \mu \mathrm{L}$ ). A imunização foi composta por $1 \times 10^{5}$ leveduras de Cryptococcus gattii contendo uma delgada cápsula polissacarídica (H.K-Thin) que foram inativadas por calor Heat-killed (H.K.) e associadas ou não (Imunizado) com $1 \mu \mathrm{g}$ de Pam3CSk4 (Imunizado+P3C4) (InvivoGen). A 
modificação na espessura da cápsula das leveduras e a inativação por calor foram realizadas conforme Ikeda-Dantsuji, Y., et al, 2015. Os animais foram submetidos a três períodos de imunização com intervalos de sete dias e, ao final dessa etapa, o sangue foi coletado em três períodos $(7,14$ e 21 dias) com intervalo de sete dias na etapa pósimunização (d.p.i), conforme Esquema 1. Para a coleta de sangue, os animais foram imobilizados em contensor específico, a cauda limpa com álcool 70\% e posteriormente aquecida com lâmpada específica para dilatação da veia lateral da cauda. Os animais foram eutanasiados nos dias 14 ou 21 pós-imunização, após anestesia com $160 \mathrm{mg} / \mathrm{Kg}$ de cloridrato de cetamina e $14 \mathrm{mg} / \mathrm{Kg}$ de cloridrato de xilazina (overdose), seguido de deslocamento cervical.

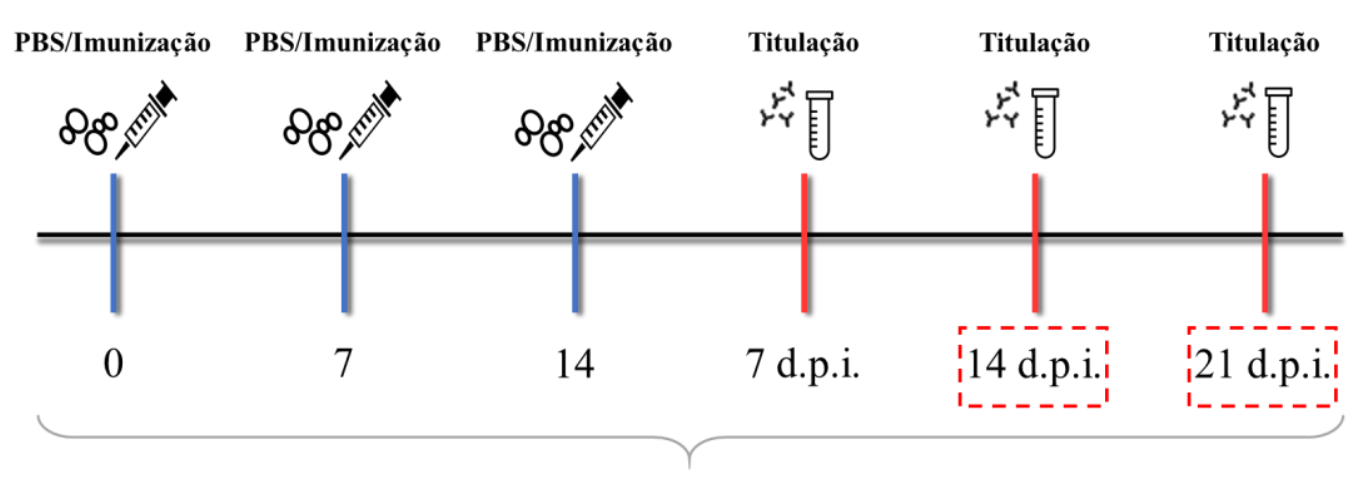

Protocolo de imunização (35 dias)

Esquema 1. Protocolo A de imunização dos camundongos BALB/c. A administração intranasal de PBS ou imunização (leveduras inativadas de $C$. gattii, associadas ou não com $1 \mu \mathrm{g}$ de Pam3CSk4) foi feita nos dias 0,7 e $14 \mathrm{em}$ animais BALB/c. Foi realizada a coleta de sangue dos animais 7, 14 e 21 dias pósimunização (d.p.i.) para a titulação de anticorpos. A eutanásia dos animais foi feita em 14 ou 21 d.p.i. (dias pontilhados em vermelho) para avaliar o perfil da resposta imunitária do hospedeiro, conforme os objetivos específicos correspondentes. A etapa do protocolo A de imunização teve duração total de 35 dias.

\section{Protocolo A de imunização seguido pelo desafio com Cryptococcus gattii}

Para verificar a eficácia do protocolo A de imunização demonstrado no Esquema 1, os animais foram infectados via intranasal com $1 \times 10^{5}$ leveduras de C. gattii (20 $\mu \mathrm{L}$ de solução) após 21 dias do período de imunização, conforme Esquema 2. Os animais foram anestesiados com cloridrato de quetamina $(80,0 \mathrm{mg} / \mathrm{Kg})$ e cloridrato de xilazina (7 $\mathrm{mg} / \mathrm{Kg}$ ) via intraperitoneal (i.p.), previamente a infusão intranasal.

A análise da curva de sobrevida dos animais submetidos ao protocolo A de imunização com posterior infecção com $C$. gattii considerou os mesmos procedimentos descrito no parágrafo anterior, e os animais foram acompanhados diariamente para determinar a taxa de sobrevida. O período total de infecção foi de 34 dias. 


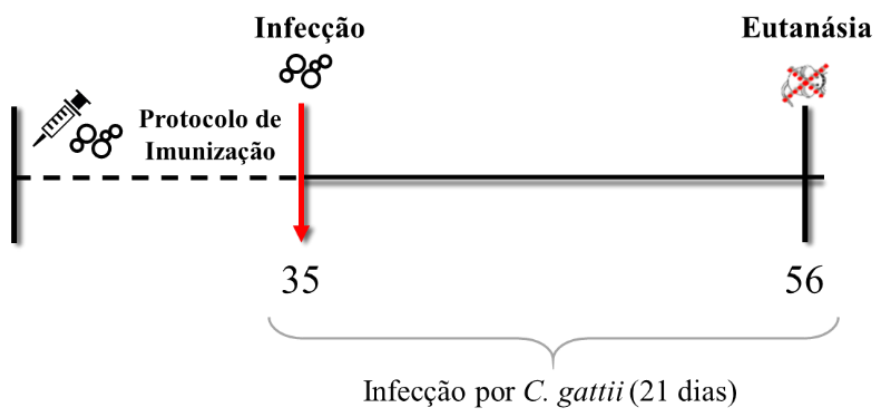

Esquema 2. Protocolo A de imunização seguido pela infecção com $C$. gattii dos camundongos BALB/c. Os animais imunizados, conforme o protocolo A de imunização descrito no Esquema 1, foram infectados via intranasal com $C$. gattii ( $1 \times 10^{5}$ leveduras viáveis) no $35^{\circ}$ dia (21 dias pós-imunização). Após 21 dias de infecção, foi realizada a eutanásia dos animais (dia 56, período total do protocolo) para avaliar a progressão da infecção fúngica através da determinação da carga fúngica pulmonar.

\section{Protocolo B de imunização e a realização do desafio com Cryptococcus gattii}

Foram utilizados 15 camundongos C57BL/6 em cada replicata experimental sendo divididos igualmente em 3 grupos: PBS (grupo controle), Imunizado (imunizados apenas com leveduras inativadas de C. gattii) e Imunizado+P3C4 (imunizados com leveduras inativadas de $C$. gattii associadas a $1 \mu \mathrm{g}$ ou $10 \mu \mathrm{g}$ de Pam3CSk4). Os camundongos C57BL/6 foram anestesiados com cloridrato de quetamina $(80,0 \mathrm{mg} / \mathrm{Kg}) \mathrm{e}$ cloridrato de xilazina $(7 \mathrm{mg} / \mathrm{Kg}$ ) via intraperitoneal (i.p.) e imunizados via intranasal (i.n.). A imunização foi composta por $2 \times 10^{7}$ leveduras de $C$. gattii contendo uma delgada cápsula polissacarídica (H.K-Thin) que foram inativadas por calor Heat-killed (H.K.), sendo associado ou não (Imunizado) com $1 \mu \mathrm{g}$ (Imunizado+P3C4-1 $\mu \mathrm{g}$ ) ou $10 \mu \mathrm{g}$ (Imunizado+P3C4-10 $\mu$ g) de Pam3CSk4 (InvivoGen). Volume final de $20 \mu \mathrm{L}$ foi utilizado na imunização intranasal. A modificação na espessura da cápsula das leveduras e a inativação por calor foram realizadas conforme Ikeda-Dantsuji, Y. et al, 2015. Os animais foram submetidos a três períodos de imunização com intervalos de 14 dias. Ao final desse período, o sangue foi obtido nos períodos 7 e 14 d.p.i. perfazendo um intervalo de quatorze dias, conforme Esquema 3A. Para a coleta de sangue, os animais foram imobilizados em contensor específico, a cauda limpa com álcool 70\% e posteriormente aquecida com lâmpada específica para dilatação da veia lateral da cauda.

$\mathrm{Na}$ avaliação do protocolo B de imunização demonstrado no Esquema 3A, os animais foram infectados via intranasal com $1 \times 10^{5}$ leveduras de C. gattii $(20 \mu \mathrm{L}$ de solução) no $42^{\circ}$ dia do protocolo (14 d.p.i), conforme demonstrado no Esquema 3B. No $56^{\circ}$ dia, ou seja, 14 dias pós-imunização, os animais foram eutanasiados após anestesia com $160 \mathrm{mg} / \mathrm{Kg}$ de cloridrato de cetamina e $14 \mathrm{mg} / \mathrm{Kg}$ de cloridrato de xilazina 
(overdose), seguido de deslocamento cervical. Os animais foram infectados, conforme descrito no item 3.1.

A

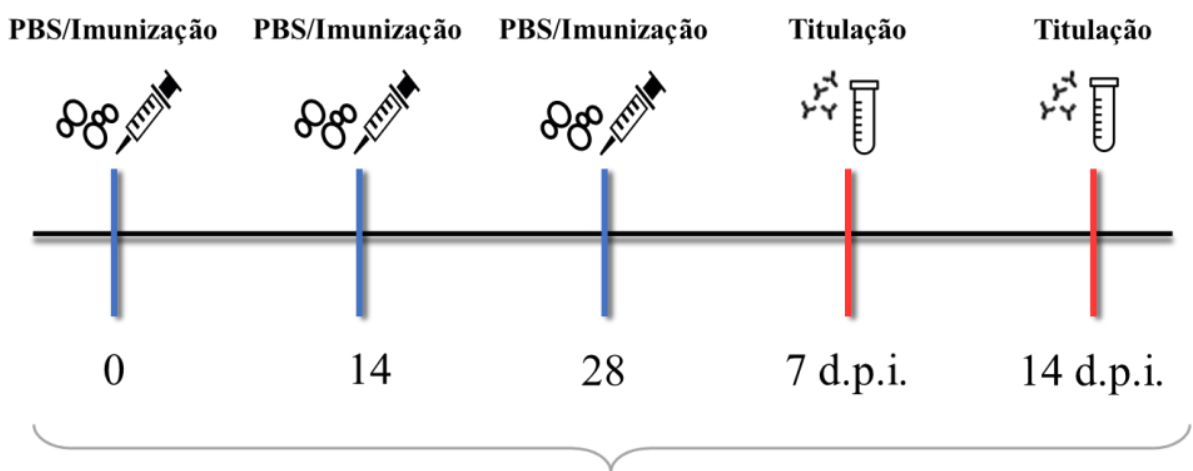

Protocolo de imunização (42 dias)

B

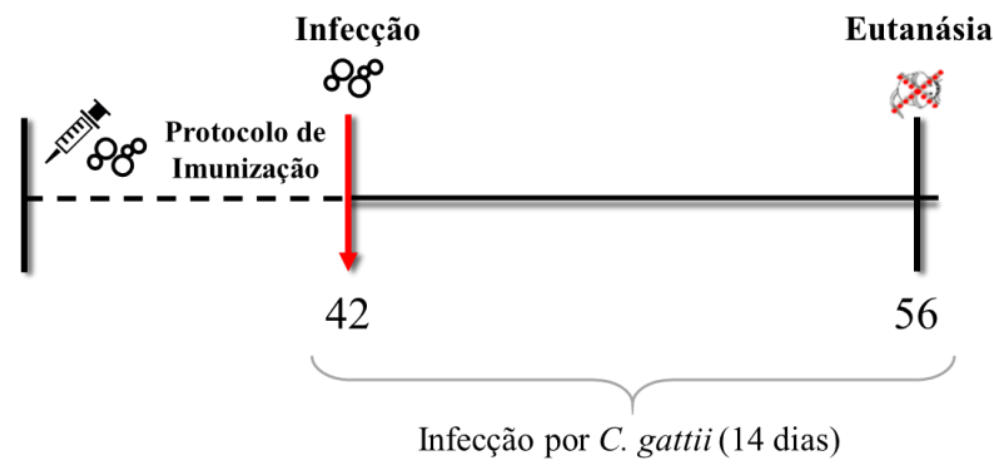

Esquema 3. Protocolo B de imunização e infecção com $C$. gattii dos camundongos C57BL/6. (A) A administração intranasal de PBS ou imunização (leveduras inativadas de $C$. gattii, associadas ou não com $1 \mu \mathrm{g}$ ou $10 \mu \mathrm{g}$ de Pam3CSk4) foi feita nos dias $0,14 \mathrm{e} 28 \mathrm{em}$ animais C57Bl/6. Foi realizada a coleta de sangue dos animais 7 e 14 dias pós-imunização (d.p.i.) para titulação de anticorpos. (B) No dia 42 (14 d.p.i), os animais foram infectados via intranasal com C. gattii ( $1 \times 10^{5}$ leveduras viáveis). Após 14 dias de infecção, foi realizada a eutanásia dos animais para avaliar a progressão da infecção fúngica e o perfil da resposta imunitária do hospedeiro. Esse protocolo teve duração de 56 dias.

\section{Isotipagem de imunoglobulinas séricas}

O soro dos animais foi utilizado para determinar os níveis das imunoglobulinas IgG1, IgG2a, IgG2b, IgG3, IgM, IgA e cadeias leves Kappa e Lambda (Easy-Titer ${ }^{\mathrm{TM}}$ Mouse IgG Assay Kit; ThermoFischer), conforme descrito pelo fabricante. No protocolo A de imunização, as dosagens foram feitas no $21^{\circ}, 28^{\circ}$ e $33^{\circ}$ dias (7, 14 e 21 d.p.i.) da etapa de imunização. No protocolo B de imunização, as dosagens foram feitas após 14 dias de infecção. 


\section{Titulação de IgG e IgM sérico total e específico para GXM}

A titulação de anticorpos IgG e IgM específicos para GXM no soro dos animais foi feita através de ELISA, utilizando o kit Easy-Titer ${ }^{\mathrm{TM}}$ Mouse IgG Assay Kit e EasyTiter $^{\mathrm{TM}}$ Mouse IgM Assay Kit; ThermoFischer, conforme instruções do fabricante. No protocolo A de imunização, a titulação de IgG-anti-GXM foi realizada nos dias 28 e 33 (7 e 14 d.p.i.) na etapa de imunização. No protocolo B de imunização, a titulação de IgG e IgM-anti-GXM foi realizada nos dias 35 e 42 (7 e 14 d.p.i.) no soro dos animais imunizados com C. gattii-H.K. associado com $1 \mu \mathrm{g}$ de Pam3CSk4.

\section{Quantificação dos níveis de citocinas por ELISA}

A dosagem de citocinas foi realizada por ensaio imunoenzimático (ELISA) utilizando o Kit OptEIATM (Pharmingen, San Diego, CA, USA), conforme as instruções do fabricante. As citocinas dosadas foram: IFN- $\gamma$, IL-12(p40), IL-12(p70), IL-10, IL-4, IL-17A, TNF- $\alpha$, IL-1 $\beta$, IL-2 e IL-6. No protocolo A de imunização, as dosagens de citocinas no baço e pulmão foram realizadas nos dias 28 e 33 (7 e 14 d.p.i.). No protocolo B de imunização, as dosagens de citocinas no pulmão e soro foram realizadas 14 dias após a infecção. O cálculo dos valores em pg/mL foi realizado no programa Prisma 7.0 (GraphPad Software), e no caso da quantificação de citocinas no tecido os dados em $\mathrm{pg} / \mathrm{mL}$ foram normalizados em relação à massa do órgão $(\mathrm{mg})$, tendo como parâmetro a leitura obtida com a curva padrão.

\section{Quantificação da produção de TNF- $\alpha$ por células esplênicas obtidas de camundongos submetidos ao protocolo A de imunização, em resposta ao estímulo com LPS ou C. gattii}

Os leucócitos esplênicos foram isolados do baço dos camundongos submetidos ao protocolo de imunização A, de acordo com o protocolo de Chaturvedi et al. A suspensão de leucócitos esplênicos foi estimulada com LPS $(0,1 \mu \mathrm{g} / \mathrm{mL})$ ou incubado com leveduras de . gattii (MOI 1:2) por 18h para avaliação da produção de TNF- $\alpha$.

\section{Avaliação da carga fúngica pulmonar}


Os camundongos foram utilizados para a retirada asséptica do pulmão. Os órgãos foram pesados, e divulsionados em homogeneizador de tecidos (IKA® - Werke) em frascos contendo PBS $1 \mathrm{X}$ estéril ( $\mathrm{pH} 7,2)$. Posteriormente, $50 \mu \mathrm{L}$ do macerado de cada um dos órgãos dos animais foi semeado, em duplicatas, em placas de Petri contendo meio Sabouraud dextrose agar (Oxoid). As placas foram mantidas a $30^{\circ} \mathrm{C}$ por até 48 horas para o crescimento das colônias de $C$. gattii. A quantidade de fungo no pulmão foi avaliada a partir da contagem de unidades formadoras de colônia (CFU); o número de CFU foi determinado por grama de órgão (CFU/g). No protocolo A de imunização, a avaliação da carga fúngica foi realizada após 21 dias de infecção com $C$. gattii. No protocolo B de imunização, a avaliação da carga fúngica foi realizada após 14 dias.

\section{Fenotipagem dos leucócitos pulmonares por citometria de fluxo}

A partir da contagem de células em câmara de Neubauer, foram utilizadas $1 \times 10^{6}$ células/mL em suspensão que foram marcadas com anticorpos conjugados a fluoróforos. As células foram incubadas por 30 minutos a $4^{\circ} \mathrm{C}$ com $0,5 \mu \mathrm{g}$ de anti-CD16/CD32 mAb (Fc block, clone 2.4G2, BD Pharmingen, San Diego, CA). Após, foram utilizados 5 $\mu \mathrm{g} / \mathrm{mL}$ dos seguintes anticorpos específicos: anti-CD3 (PE-Cy5 Rat anti-Mouse CD3; clone 17A2; BD Pharmingen), anti-CD4 (FITC Rat anti-Mouse CD4; clone H129.19; BD Pharmingen), anti-CD8 (PE Rat anti-Mouse CD8; clone 53-6.7; BD Pharmingen), antiF4/80 (FITC Rat anti-Mouse F4/80; clone BM8; BD Pharmingen), anti-CD11b (Alexa Fluor 488 Rat Anti-Mouse CD11b; clone M1/70; BD Pharmingen), anti- CD11c (PE Hamster Anti-Mouse CD11c; clone HL3; BD Pharmingen), anti-Ly-6G (PerCP-Cy ${ }^{\text {TM} 5.5}$ Rat Anti-Mouse Ly-6G; clone RB6-8C5; BD Pharmingen), anti-TLR2-PE (PE Rat AntiMouse TLR2; clone 6C2; BD Pharmingen). Nessa etapa, a incubação foi feita por 45 minutos. Depois, as células foram lavadas duas vezes com PBS e fixadas com PBSformaldeído (1\%). Após essas etapas, foi feita a análise por citometria de fluxo (Guava EasyCyteTM Mini System).

\section{Análise do perfil de células $\mathrm{T} \mathrm{CD4}^{+}$e subtipos de macrófagos no tecido pulmonar através de qRT-PCR}


Os transcritos de T-bet, ROR- $\gamma$ t, GATA-3, Foxp3, IL-23, TGF- $\beta$, STAT-1, STAT-3 e STAT-5 foram avaliados para determinar a diferenciação de células T CD4+, e os transcritos de Arginase-1 e iNOS foram investigados na polarização de macrófagos através de qRT-PCR. O RNA foi extraído utilizando o reagente TRIzol (Life Technologies, Carlsbad, CA, USA) conforme descrito pelo fabricante. O RNA total foi utilizado para conversão em cDNA utilizando o kit iScript ${ }^{\mathrm{TM}}$ cDNA Synthesis (Bio-Rad). A reação de qRT-PCR foi realizada em um volume final de $10 \mathrm{uL}$ utilizando EvaGreen (Bio-Rad). Para a leitura do qRT-PCR foi utilizado o equipamento CFX96 (Bio-Rad) considerando as seguintes condições de reação: $95^{\circ} \mathrm{C}$ por $30 \mathrm{seg}, 40$ ciclos de $95^{\circ}$ por 05 seg $/ 60^{\circ} \mathrm{C}$ por $5 \mathrm{seg}, 91,5^{\circ} \mathrm{C}-95^{\circ} \mathrm{C}$ por 5 seg. A expressão relativa do transcrito foi quantificada usando o método $\Delta \Delta \mathrm{Ct}$ e normalizado para a expressão de $\beta$-actina. Os primers utilizados para a reação de PCR foram: $\beta$-actin (F-5'CCTAAGGCCAACCGTGAAAA-3', R-5'-GAGGCATACAGGGACAGCACA-3'), Tbet (F: 5'-CACTAAGCAAGGACGGCGAA-3' CCACCAAGACCACATCCAC-3'), Ror- $\gamma t$ (F: 5'-TGGAAGATGTGGACTTCGTT-3'\% R: 5'-TGGTTCCCCAAGTTCAGGAT-3''), Gata3 (F: 5'AAGAAAGGCATGAAGGACGC-3'/R: 5'-GTGTGCCCATTTGGACATCA-3'), Arginase-1 (F: 5'-GTTCCCAGATGTACCAGGATTC-3', R: 5'CGATGTCTTTGGCAGATATGC-3'), iNOS2 (F: 5'CCGAAGCAAACATCACATTCA-3', R: 5'-GGTCTAAAGGCTCCGGGCT-3'), IL23 (F: 5'TCCGTTCCAAGATCCTTCGA3' / R: 5'TGTTGGCACTAAGGGCT CAG3'), Foxp3 (F: 5'-ATtGAGGGTGGGTGTCAGGA-3' / R: 5'TCCAAGTCTCGTCTGAAGGCA-3'), STAT3 $\quad$ (F: 5'TGTTAAATTTCCGAGACCCTC / R: 3'- CCAGTTTACCACGAAAGTCAG), STAT1 (F: 5'- CACGCTGCCTATGATGTC / R: 3'- CCTGGAGATTACGCTTGC), STAT5 (F: 5'- CCCTCAACCTCACTACAAC / R: CGGCGTAAAAGTTCTTCCAC), TGF- $\beta$ (F: 5'-GACTCTCCACCTGCAAGACC-3' / R: 5'-GGGACTGGCGAGCCTTAGTT-3'). O transcrito de $\beta$-actina foi utilizado como controle endógeno.

\section{Avaliação histopatológica do pulmão}

Para a análise histopatológica, o pulmão foi imediatamente perfundido com PBS estéril através do ventrículo direito. Após excisar o pulmão, o fragmento foi fixado em solução de metacarn $(60 \%$ de metanol absoluto, $30 \%$ de clorofórmio e $10 \%$ de ácido 
acético glacial vol/vol) por $48 \mathrm{~h}$, e posteriormente desidratados, clarificados em xilol, embebidos em parafina e seccionados $(5 \mu \mathrm{m})$. Os cortes foram corados com HematoxilinaEosina (H\&E) e, posteriormente, avaliados por microscopia de luz (Nikon, Eclipse E800).

\section{Análise estatística}

Para a análise estatística foi utilizado o programa Prisma 7.0 (GraphPad Software). Em todas as variáveis foram testadas a distribuição normal e realizada a análise de variância. Confirmada a distribuição normal e variância homogênea, foi aplicado o teste One-way ANOVA com pós-teste de Bonferroni, estabelecendo como controle o grupo imunizado; ou Teste t de Student para análise de 2 grupos. Quando a distribuição dos dados não foi normal e a variância não foi homogênea, foi aplicado o teste de KruskalWallis com pós-teste de Dunn's; ou teste de Mann-Whitney para análise de 2 grupos. Os resultados foram expressos em média \pm SD (Desvio Padrão), com as diferenças observadas sendo consideradas significativas quando $\mathrm{p}<0,05\left(^{*}\right)$. 
RESULTADOS 


\section{Capítulo I}

Título: Efeito in vitro de Pam3CSk4 na linhagem de macrófago alveolar AMJ2-C11 


\subsection{Nível de expressão do receptor TLR2 em resposta ao estímulo com Pam3CSk4}

Tendo em vista que um objetivo específico do presente trabalho buscou avaliar a eficácia do agonista de TLR2 (Pam3CSk4) como agente modulador da resposta imune inata, após infusão intranasal, investigamos a atividade imunomoduladora de Pam3CSk4 na linhagem de macrófago alveolar AMJ2-C11. O nível de expressão do receptor TLR2 em AMJ2-C11 incubada com Pam3CSk4 $(1 \mu \mathrm{g} / \mathrm{mL})$ por 16 horas foi determinado por citometria de fluxo. Observamos que a totalidade de células AMJ2-C11 expressam constitutivamente TLR2 (Figura 1B), e as células AMJ2-C11 estimuladas com Pam3CSk4 apresentaram um aumento na intensidade de fluorescência para a expressão de TLR2 em comparação às células AMJ2-C11 não estimuladas (Figura 1C, D).

A
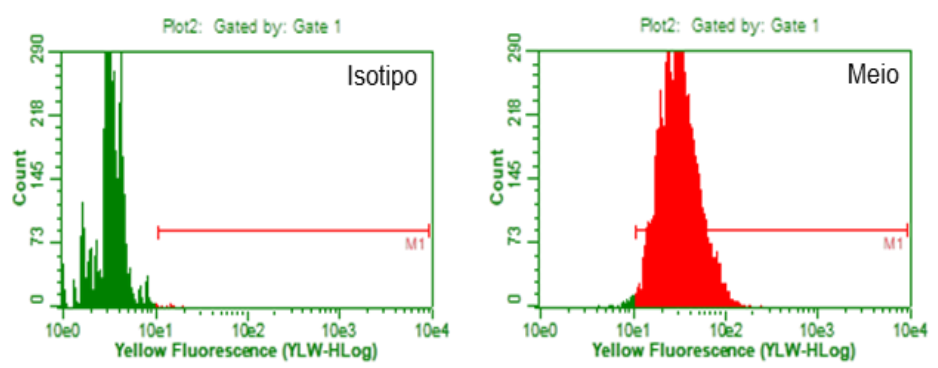

C

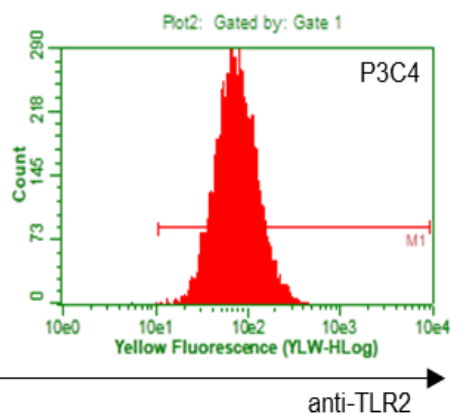

D

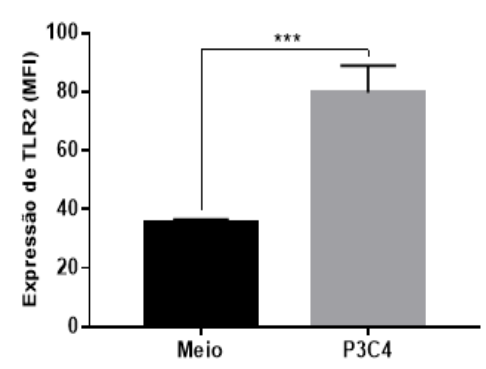

Figura 1. Expressão de TLR2 em células AMJ2-C11 após estímulo com Pam3CSk4. Células AMJ2C11 $\left(1 \times 10^{5}\right.$ cél $\left./ \mathrm{mL}\right)$ foram incubadas somente com meio de cultivo (B, controle negativo) ou com Pam3CSk4 $(1 \mu \mathrm{g} / \mathrm{mL})(\mathbf{C})$. Após $16 \mathrm{~h}$, as células AMJ2-C11 foram incubadas com anticorpo monoclonal anti-TLR2-PE (PE Rat Anti-Mouse TLR2; clone 6C2; BD Pharmingen) e a porcentagem de células positivas e a intensidade média de fluorescência foi mensurada por citometria de fluxo. As células AMJ2C11 incubadas somente com Isotipo controle ( $\operatorname{IgG})$ foram adotadas na calibração do equipamento (A). A linha contínua vermelha presente nos histogramas representa a região de células positiva para a detecção de anti-TLR2. A média da intensidade de fluorescência (MFI) da replicata experimental está representada no gráfico de barras (D). Os valores foram expressos como média \pm DP, e a diferença significativa em relação ao grupo controle (Meio) quando $\mathrm{p}<0,001(* * *)$. 


\subsection{Perfil de polarização dos macrófagos alveolares AMJ2-C11 induzido por Pam3CSk4}

A ativação clássica e alternativa dos macrófagos resultam em células de subtipo M1 (clássico) e subtipo M2 (alternativo) caracterizadas pelo perfil de resposta pró- e antiinflamatória, respectivamente. Nesse sentido, o efeito de Pam3CSk4 no perfil de polarização das células AMJ2-C11 foi investigado através da quantificação dos níveis de produção de TNF- $\alpha$ e pela mensuração da expressão relativa dos transcritos de iNOS, Arginase-1 e IL-23 (Figura 2). Para isso, as células AMJ2-C11 foram estimuladas com Pam3CSk4 (1 $\mu \mathrm{g} / \mathrm{mL})$, IL-4 (40 ng/mL), PMA (50 ng/mL) + Ionomicina $(1 \mu \mathrm{M})$ ou somente meio de cultivo (Meio). Após 24 h de incubação, os níveis de TNF- $\alpha$ no sobrenadante do cultivo celular foram mensurados por ELISA e as células AMJ2-C11 incubadas com Pam3CSk4 apresentaram um aumento significativo nos níveis de TNF- $\alpha$ comparado com as células não estimuladas (Meio) (Figura 2A).

As células AMJ2-C11 estimuladas com Pam3CSk4 (1 $\mu \mathrm{g} / \mathrm{mL}), \mathrm{IL}-4$ (40 ng/mL) ou somente meio de cultivo (Meio) foram utilizadas na extração de RNA para quantificar a expressão relativa dos marcadores específicos para os subtipos M1 e M2 de macrófagos. $\mathrm{A}$ adição de Pam3CSk4 às células AMJ2-C11 induziu um aumento significativo da expressão relativa de iNOS (Figura 2B), marcador específico do perfil M1, enquanto a expressão relativa de arginase-1 não diferiu significativamente dos níveis detectados nas células não estimuladas (Figura 2C). Além disso, células AMJ2-C11 estimuladas com Pam3CSk4 tiveram um aumento significativo da expressão relativa de IL-23 (Figura 2D). Esses dados demonstram que Pam3CSk4 é capaz de induzir a polarização de macrófago alveolar AMJ2-C11 para o perfil M1 de caráter pró-inflamatório e com elevada atividade microbicida, e se destaca a indução de citocina de perfil Th17. 

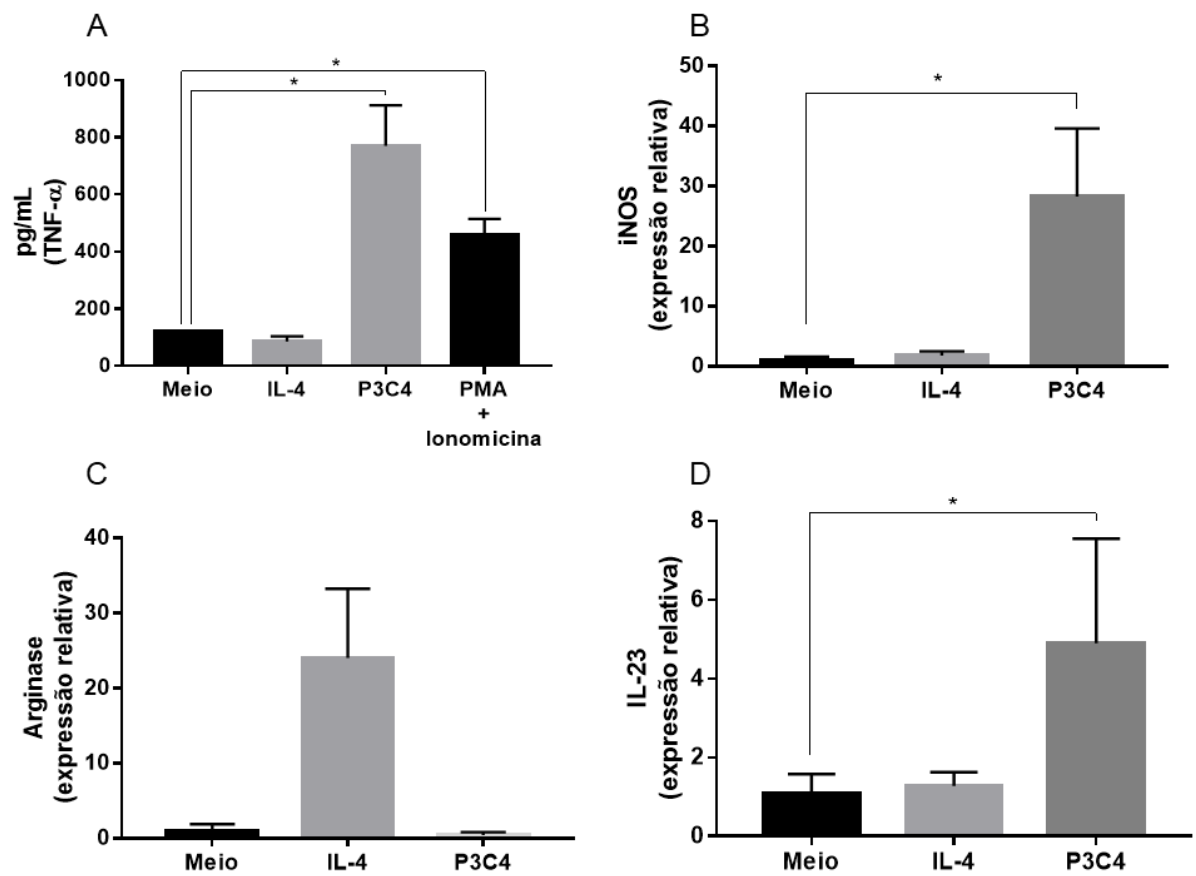

Figura 2. Polarização das células AMJ2-C11 sob o estímulo de Pam3CSk4. (A) Células AMJ2-C11 $\left(1 \times 10^{4}\right.$ células $\left./ \mathrm{mL}\right)$ foram estimuladas com IL-4 (40 ng/mL), P3C4 (1 $\left.\mu \mathrm{g} / \mathrm{mL}\right)$, PMA $(50 \mathrm{ng} / \mathrm{mL})$ + Ionomicina $(1 \mu \mathrm{M})$ ou somente meio (Meio), por $24 \mathrm{~h}$ de incubação. Os sobrenadantes foram coletados e os níveis de TNF- $\alpha$ quantificado por ELISA, e os valores estão expressos em pg/mL. (B, C e D) Células

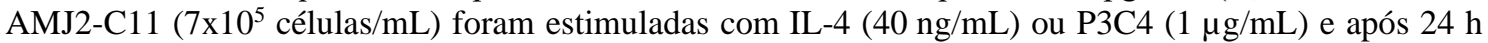
de incubação o RNA foi extraído para conversão em cDNA. A expressão relativa de iNOS (B), Arginase1 (C) e IL-23 (D) foi determinada por qRT-PCR, os valores de $\Delta \Delta \mathrm{Ct}$ foram utilizados para determinar a expressão relativa tendo como controle endógeno o transcrito de $\beta$-actina. Os valores foram expressos como média \pm DP, com $\mathrm{p}<0,05\left(^{*}\right)$ para diferença significativa em comparação ao grupo controle "Meio".

\subsection{Atividade fagocítica e fungistática de macrófagos alveolares AMJ2-C11 estimulados com Pam3CSk4 sobre leveduras de $C$. gattii}

A polarização de macrófagos AMJ2-C11 para o subtipo M1 induzido por Pam3CSk4 pressupõe uma elevada atividade fagocítica e microbicida, com isso, analisamos a atividade fagocítica e fungistática de células AMJ2-C11 estimuladas com Pam3CSk4 frente à infecção com C. gattii. Os macrófagos alveolares foram estimulados com Pam3CSk4 (1 $\mu \mathrm{g} / \mathrm{mL}), \mathrm{IL}-4$ (40 ng/mL), IFN- $\gamma(40 \mathrm{ng} / \mathrm{mL})$ ou somente meio de cultura (Meio) por $24 \mathrm{~h}$ de incubação e, em seguida, as células AMJ2-C11 foram cocultivadas com $C$. gattii. Na análise da atividade fagocítica, a co-cultura de leveduras de C. gattii e células AMJ2-C11, previamente estimuladas ou não, foi realizada na razão de 1:10 (macrófago alveolar: levedura) e cultivada por $5 \mathrm{~h}$. Em seguida, as leveduras não aderidas/fagocitadas foram removidas após etapa de lavagem com PBS estéril, e os macrófagos alveolares foram desaderidos e lisados para mensurar a carga fúngica por CFU em ágar Sabouraud. Observamos uma carga de C. gattii significativamente maior 
em células AMJ2-C11 previamente estimulados com Pam3CSk4 em comparação às células não estimuladas (Meio) (Figura 3A). Isso demonstra a capacidade de Pam3CSk4 em induzir maior atividade fagocítica de AMJ2-C11 frente as leveduras de C. gattii.

Para analisar a atividade fungistática de células AMJ2-C11 estimuladas com Pam3CSk4, os macrófagos alveolares foram co-cultivados com leveduras de C. gattii na razão de 1:10 (levedura: macrófago alveolar) por $24 \mathrm{~h}$ e, simultaneamente, foi adicionado Pam3CSk4 (1 $\mu \mathrm{g} / \mathrm{mL}), \mathrm{IL}-4(40 \mathrm{ng} / \mathrm{mL}), \mathrm{IFN}-\gamma(40 \mathrm{ng} / \mathrm{mL})$ ou somente meio de cultura (Meio) na co-cultura. Posteriormente, os macrófagos alveolares foram desaderidos, lisados e homogeneizados com o sobrenadante do cultivo celular para mensurar o CFU de $C$. gattii. Os macrófagos alveolares estimulados com Pam3CSk4 ou IFN- $\gamma$ apresentaram uma carga fúngica significativamente maior quando comparado às células não estimuladas (Meio), demonstrando que o perfil de ativação induzido por Pam3CSk4 em células AMJ2-C11 não favorece o controle do crescimento de C. gattii (Figura 3B).

A

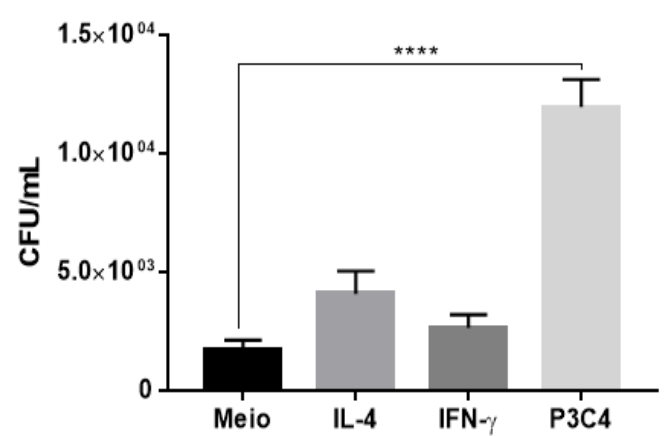

B

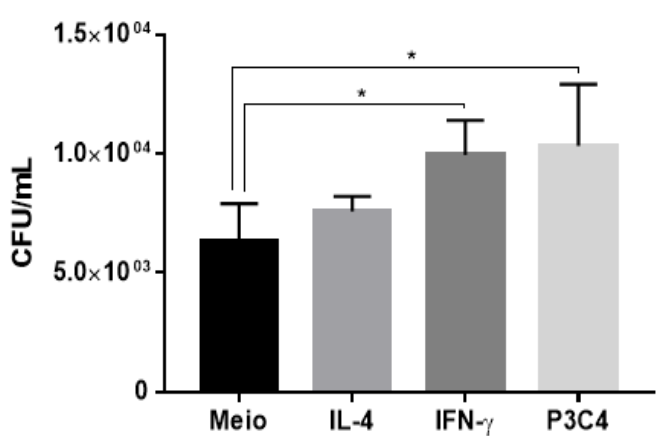

Figura 3. Fagocitose e atividade fungistática de células AMJ2-C11 estimuladas com Pam3CSk4 e cocultivadas com $\boldsymbol{C}$. gattii. (A) Atividade fagocítica, macrófagos alveolares $\left(1 \times 10^{4}\right.$ células $\left./ \mathrm{mL}\right)$ foram estimulados com IL-4 (40 ng/mL), IFN- $\gamma(40 \mathrm{ng} / \mathrm{mL})$, P3C4 $(1 \mu \mathrm{g} / \mathrm{mL})$ ou somente meio de cultivo (Meio). Após $24 \mathrm{~h}$ de incubação, as células AMJ2-C11 foram infectadas com $1 \times 10^{5}$ leveduras por $5 \mathrm{~h}$, e as leveduras não aderidas foram removidas após lavagem com PBS $1 \mathrm{X}$ estéril. Os macrófagos foram desaderidos e lisados e a suspensão foi semeada em ágar Sabouraud dextrose para determinar o CFU. (B) Atividade fungistática, macrófagos alveolares $\left(1 \times 10^{4}\right.$ células $\left./ \mathrm{mL}\right)$ foram estimulados com IL-4 $(40 \mathrm{ng} / \mathrm{mL})$, IFN- $\gamma(40$ $\mathrm{ng} / \mathrm{mL}), \mathrm{P} 3 \mathrm{C} 4(1 \mu \mathrm{g} / \mathrm{mL})$ ou somente meio de cultivo (Meio), e simultaneamente infectados com $1 \times 10^{3}$ leveduras. Após $24 \mathrm{~h}$ de incubação, os macrófagos foram desaderidos, lisados e homogeneizados ao sobrenadante e o CFU foi realizado em ágar Sabouraud dextrose. Os valores foram expressos como média $\pm \mathrm{DP}, \operatorname{com} \mathrm{p}<0,05\left(^{*}\right)$ para diferença significativa em comparação ao grupo controle (Meio).

\subsection{Produção de TNF- $\alpha$ por células AMJ2-C11 incubadas com Pam3CSk4 e co- cultivadas com $C$. gattii}

Visto que Pam3CSk4 induz a ativação de macrófagos alveolares AMJ2-C11 que repercutiu no aumento da atividade fagocítica frente a $C$. gattii, porém, com a 
incapacidade de controlar o crescimento in vitro de $C$. gattii, avaliamos a capacidade de C. gattii em regular a ativação das células AMJ2-C11 ativadas por Pam3CSk4. Com isso, as células AMJ2-C11 foram estimuladas com IL-4 (40 ng/mL), IFN- $\gamma(40 \mathrm{ng} / \mathrm{mL})$ e P3C4 $(1 \mu \mathrm{g} / \mathrm{mL})$ e, em seguida, as células foram co-cultivadas ou não simultaneamente com $C$. gattii (razão 1:10, levedura : macrófagos). Após 24 h de incubação, a produção de TNF$\alpha$ no sobrenadante do cultivo celular foi quantificado através de ELISA. Como demonstrado anteriormente, os macrófagos alveolares na ausência de C. gattii (barras pretas) e estimulados com Pam3CSk4 produziram níveis elevados de TNF- $\alpha$ comparado ao controle (Meio) (Figura 4). Já as células AMJ2-C11 estimuladas com Pam3CSk4 e na presença de $C$. gattii (barras cinzas) também produziram altos níveis de TNF- $\alpha$ comparado as células não estimuladas (Meio), e não houve diferença significativa entre os níveis de TNF- $\alpha$ produzidos pelas células AMJ2-C11 estimuladas com Pam3CSk4 e incubadas ou não com C. gattii (Figura 4). Com isso, observamos que a produção de TNF$\alpha$ por células AMJ2-C11 induzidas por Pam3CSk4 não é modulada pelas leveduras de $C$. gattii.

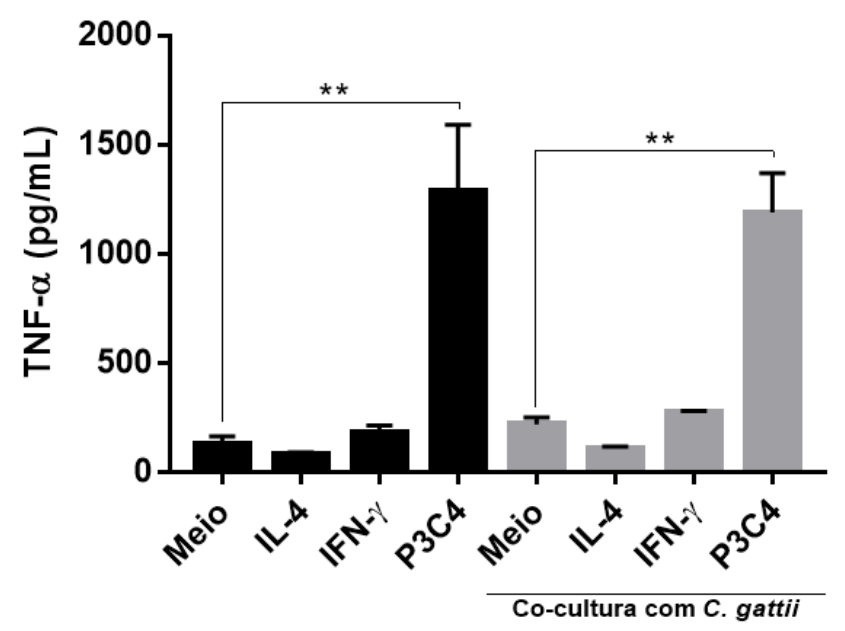

Figura 4. Produção de TNF- $\alpha$ por macrófagos alveolares AMJ2-C11 estimulados com Pam3CSk4 na ausência ou presença de $\boldsymbol{C}$. gattii. Macrófagos alveolares $\left(1 \times 10^{4}\right.$ células $\left./ \mathrm{mL}\right)$ foram estimulados com IL$4(40 \mathrm{ng} / \mathrm{mL}), \mathrm{IFN}-\gamma(40 \mathrm{ng} / \mathrm{mL}), \mathrm{P} 3 \mathrm{C} 4(1 \mu \mathrm{g} / \mathrm{mL})$ ou somente meio de cultivo (Meio) (barras pretas). Nessas mesmas condições, as células AMJ2-C11 foram co-cultivadas com C. gattii $\left(1 \times 10^{3}\right)$ de forma simultânea à adição dos estímulos (barras cinzas). Após $24 \mathrm{~h}$ de incubação, o sobrenadante foi coletado para a quantificação de TNF- $\alpha$ por ELISA (pg/mL). Os valores foram expressos como média $\pm \mathrm{DP}$, com $\mathrm{p}$ $<0,01(* *)$ para diferença significativa. 


\section{Capítulo II}

Título: Efeito de Pam3CSk4 em estratégia vacinal contra a infecção por Cryptococcus gattii em camundongos BALB/c - Protocolo A 


\subsection{Avaliação do protocolo de imunização}

\subsubsection{Isotipagem de imunoglobulinas e quantificação de IgG anti-GXM no soro de camundongos submetidos a estratégia vacinal}

A capacidade de Pam3CSk4 em induzir a polarização de macrófagos alveolares para o subtipo M1 (Figura 2) juntamente com o efeito notório desse agonista em modular a resposta imunitária do hospedeiro para um perfil desejável para o controle da criptococose, justificou a avaliação do efeito imunomodulador de Pam3CSk4 no período restrito a etapa de imunização. Com isso, adotamos um protocolo de imunização, como especificado no Esquema 1, para investigar a capacidade de Pam3CSk4, como adjuvante, em favorecer a montagem de uma resposta imune adaptativa e/ou humoral contra a infecção por C. gattii. Após aplicação do protocolo de imunização, mensuramos os níveis séricos das imunoglobulinas IgG1, IgG2a, IgG2b, IgG3, IgA, IgM e cadeias Kappa e Lambda nos dias 7 (Figura 5A), 14 (Figura 5B) e 21 dias (Figura 5C) pós-imunização. Os valores de absorbância dos diferentes isotipos de imunoglobulinas em cada grupo foram comparados a partir de um cut-off determinado pelos valores obtidos no grupo PBS, assim um aumento ou redução dos níveis dos isotipos nos grupos Imunizado e Imunizado+P3C4 foram determinados (Figura 5). Observamos a ausência de alteração significativa na D.O. dos distintos isotipos na comparação entre os grupos Imunizado, PBS e Imunizado + P3C4 nos períodos de 7 e 14 dias pós-imunização (Figura 5A-B). Por outro lado, os níveis de absorbância dos isotipos IgG1, IgG2a, IgG2b, IgM no grupo Imunizado e tratado com Pam3CSk4 tiveram uma queda em comparação ao grupo PBS (Figura 5C). Portanto, a administração de Pam3CSk4, associada ao protocolo de imunização, resultou na alteração dos níveis séricos de imunoglobulinas de distintos isotipos em períodos tardios do protocolo de imunização adotado. 


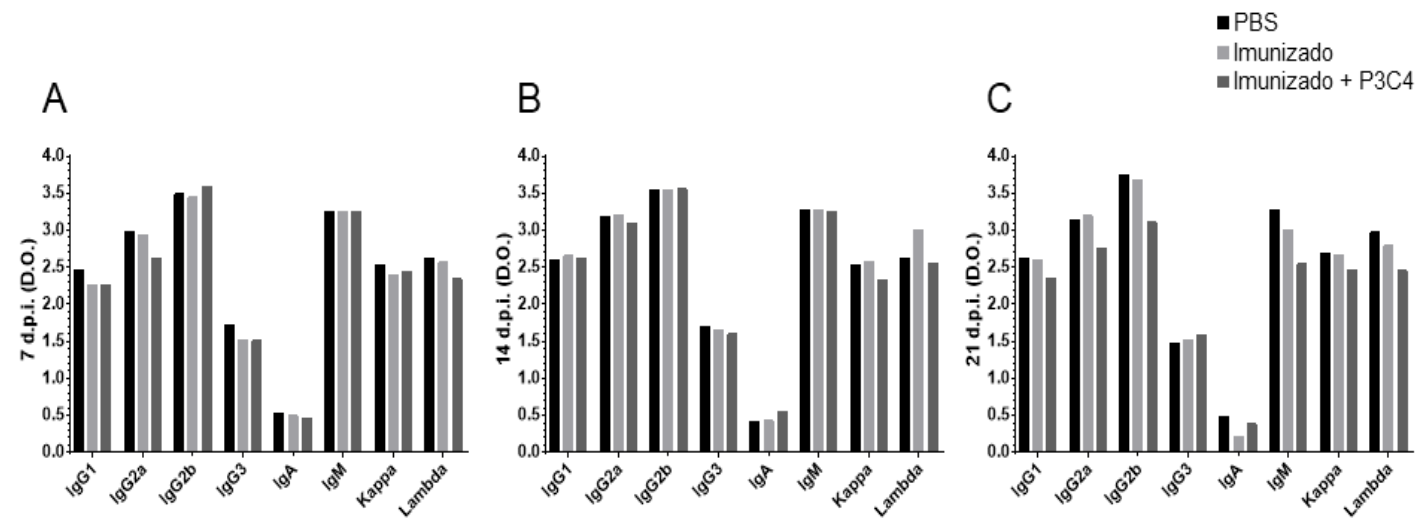

Figura 5. Isotipagem de imunoglobulinas séricas de camundongos, nos dias 7, 14 e 21 pós-imunização, durante a estratégia vacinal contra a infecção por $\boldsymbol{C}$. gattii. O soro dos animais foi obtido 7,14 e 21 dias pós-imunização para determinar os níveis dos isotipos das imunoglobulinas (IgG1, IgG2a, IgG2b, IgG3, IgA, IgM e cadeias Kappa e Lambda) nos grupos PBS, Imunizado e Imunizado+Pam3CSk4, através do kit EasyTiter ${ }^{\mathrm{TM}}$ Mouse IgG Assay (ThermoFischer) por ELISA. Os resultados foram expressos em absorbância (D.O.) após leitura em comprimento de onda de $450 \mathrm{~nm}$, e os valores estão representados em média \pm DP. Os valores encontrados no grupo PBS foram adotados como cut-off na comparação entre os grupos.

Na mesma linha da abordagem dos níveis séricos de isotipos de imunoglobulinas, os níveis de anticorpos anti-GXM foram avaliados para inferir sobre o efeito da estratégia vacinal sobre a produção de anticorpos contra o principal fator de virulência, GXM, de C. gattii. Os níveis de anticorpos IgG específicos para GXM foram quantificados no soro de camundongos dos distintos grupos, situação realizada nos dias 14 e 21 pós-imunização através de ELISA (Figura 6). Os valores expressos em D.O, relacionados aos níveis de IgG anti-GXM, não apresentaram diferenças significativas entre o grupo Imunizado comparado aos grupos PBS e Imunizado + P3C4 (Figura 6). Com isso, podemos inferir que a administração de Pam3CSk4 apresentou ser ineficaz no aumento dos níveis séricos de anticorpos específicos para a cápsula de $C$. gattii, considerando o protocolo de imunização avaliado.

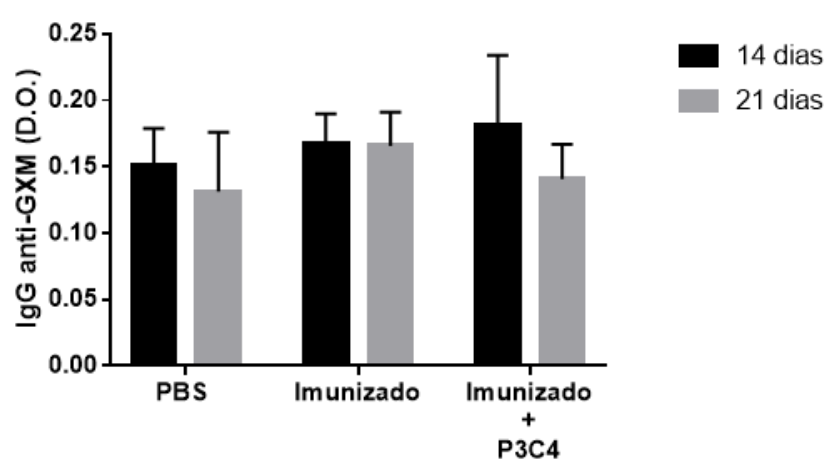

Figura 6. Quantificação de IgG anti-GXM no soro de camundongos no período de 14 e 21 dias pósimunização durante a estratégia vacinal contra a infecção por $\boldsymbol{C}$. gattii. $\mathrm{O}$ soro dos animais imunizados com leveduras inativadas de C. gattii, de forma associada ou não com Pam3CSk4, foi obtido nos dias $14 \mathrm{e}$ 21 pós-imunização e os níveis de IgG anti-GXM foram determinados por ELISA. As amostras foram diluídas 200x e os valores de absorbância (D.O.) foram utilizados para plotar o gráfico. Os animais que receberam PBS durante as etapas de imunização são considerados como grupo controle. Os valores foram expressos como média \pm DP. 


\subsubsection{Níveis de citocinas nos tecidos pulmonar e esplênico dos animais submetidos ao protocolo de imunização}

O efeito imunomodulador do processo de imunização através de leveduras inativadas de $C$. gattii, de forma associada ou não com Pam3CSk4, foi avaliado através da quantificação dos níveis de citocinas no pulmão e baço por meio de ELISA. O perfil de citocinas pró- e anti-inflamatórias foi adotado para avaliar o papel de Pam3CSk4 como adjuvante no protocolo de imunização em estudo. Após realização do protocolo de imunização (Esquema 1), o sobrenadante do homogeneizado do pulmão dos camundongos foi adotado na quantificação dos níveis de IL-12-p40 (Figura 7A), IFN- $\gamma$ (Figura 7B), TNF- $\alpha$ (Figura 7C), IL-4 (Figura 7D), IL-10 (Figura 7E) e IL-17 (Figura 7F). Essa avaliação foi realizada nos períodos de 14 e 21 dias pós-imunização nos grupos PBS, Imunizado e Imunizado+P3C4. Em relação aos níveis de citocinas detectados no tecido pulmonar no $14^{\circ}$ dia pós-imunização, nenhuma diferença significativa foi observada entre os grupos (Figura 7, barras pretas). Porém, os níveis das citocinas próinflamatórias IL-12-p40, TNF- $\alpha$ e IL-17 mensurados no tecido pulmonar no $21^{\circ}$ dia pósimunização tiveram uma redução significativa no grupo Imunizado+P3C4, comparado com o grupo Imunizado (Figura 7A, C e F). Também constatamos uma redução significativa nos níveis da citocina anti-inflamatória IL-10 no grupo Imunizado+P3C4 em relação ao grupo Imunizado (Figura 7E). Os níveis de IFN- $\gamma$ e IL-4 não diferiram entre os grupos considerando o mesmo período pós-imunização (Figura 7B e D). Portanto, a administração de Pam3CSk4 associada à imunização com leveduras inativadas de $C$. gattii não induziu um efeito imunomodulador no tecido pulmonar com prevalência de citocinas pró-inflamatórias no período pós-imunização. 

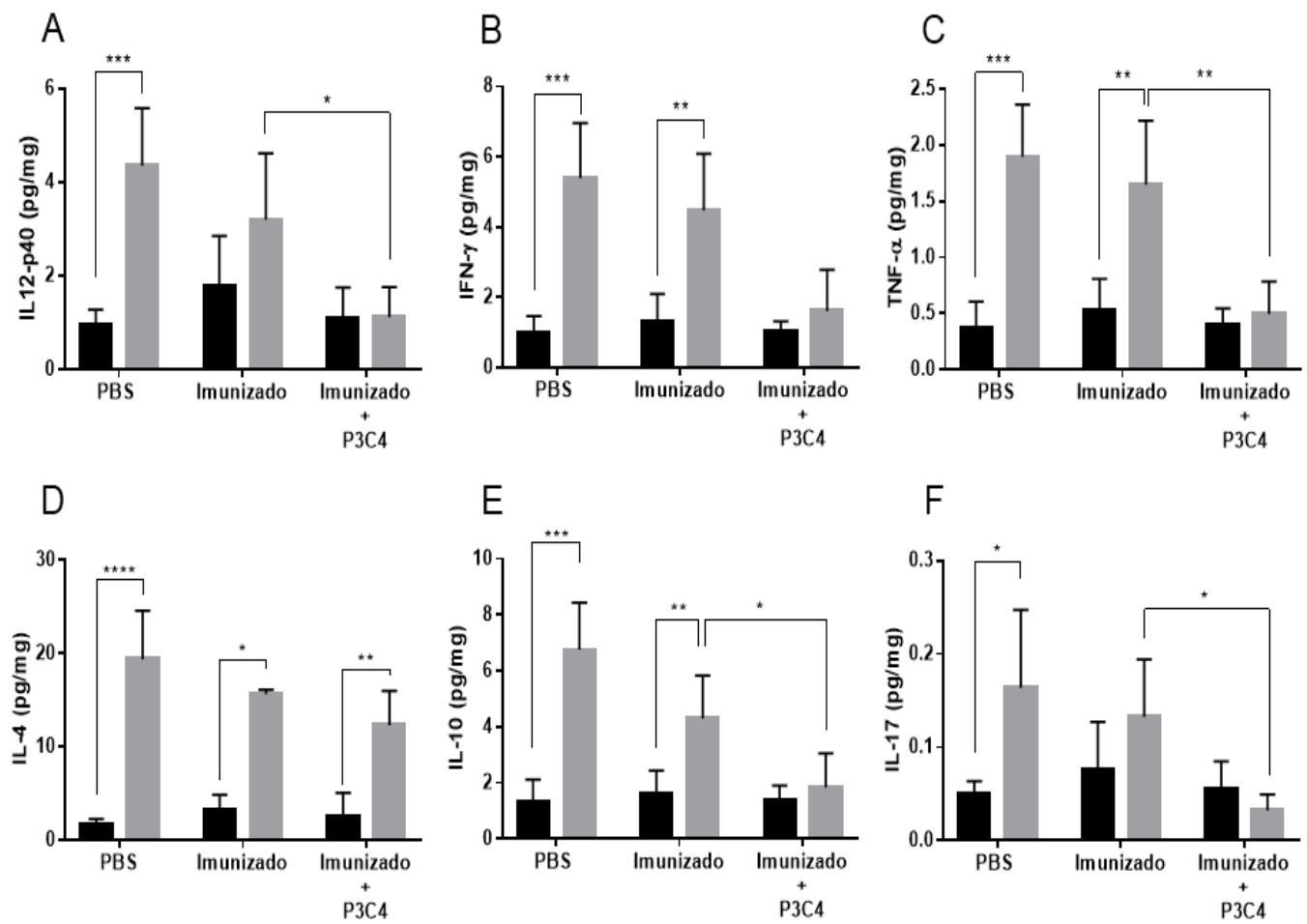

Figura 7. Níveis de citocinas no tecido pulmonar de camundongos submetidos ao protocolo de imunização e avaliados nos dias 14 e 21 pós-imunização. Os pulmões dos animais foram coletados e homogeneizados e o sobrenadante utilizado na quantificação das citocinas (A) IL-12-p40, (B) IFN- $\gamma$, (C) TNF- $\alpha$, (D) IL-4, (E) IL-10 e (F) IL-17 através de ELISA. Essa análise foi realizada após 14 dias (barra preta) e 21 dias (barra cinza) da etapa de imunização. A concentração das citocinas em $\mathrm{pg} / \mathrm{mL}$ foi normalizada em relação a massa do órgão $(\mathrm{mg})$ resultando na unidade $\mathrm{pg} / \mathrm{mg}$. Os valores foram expressos como média $\pm \mathrm{DP}$, e a diferença entre os grupos considerada significativa quando $\mathrm{p}<0,05\left(^{*}\right), \mathrm{p}<0,01$ $(* *), \mathrm{p}<0,001(* * *), \mathrm{p}<0,00001(* * * *)$.

A quantificação dos níveis de citocinas também foi determinada no baço dos animais submetidos ao protocolo de imunização com o intuito de avaliar o perfil de resposta imunitária predominante a nível sistêmico. O baço dos camundongos foi removido e homogeneizado para utilizar o sobrenadante na mensuração de IL-12-p40 (Figura 8A), IFN- $\gamma$ (Figura 8B), TNF- $\alpha$ (Figura 8C), IL-4 (Figura 8D), IL-10 (Figura 8E) e IL-17 (Figura 8F), sendo que os níveis citocínicos foram avaliados nos dias 14 e 21 pósimunização. $\mathrm{Na}$ análise das citocinas de perfil pró-inflamatório, destacamos no grupo Imunizado+P3C4 uma redução significativa nos níveis de IL-17 em comparação ao grupo Imunizado, no $21^{\circ}$ dia pós-imunização (Figura 8F). Em relação as outras citocinas próinflamatórias, os níveis entre os grupos Imunizado e Imunizado+P3C4 não alteraram de forma significativa. Por outro lado, observamos um aumento significativo nos níveis de IL-4 referente ao grupo Imunizado+P3C4, comparado ao grupo Imunizado conforme detectado no dia 21 pós-imunização (Figura 8D). Portanto, podemos inferir que a 
administração de Pam3CSk4 associada ao inóculo de leveduras inativadas de C. gattii ocasionou um efeito modulador no baço com predomínio de citocina anti-inflamatória.

14 dias pós-imunização $\square 21$ dias pós-imunização
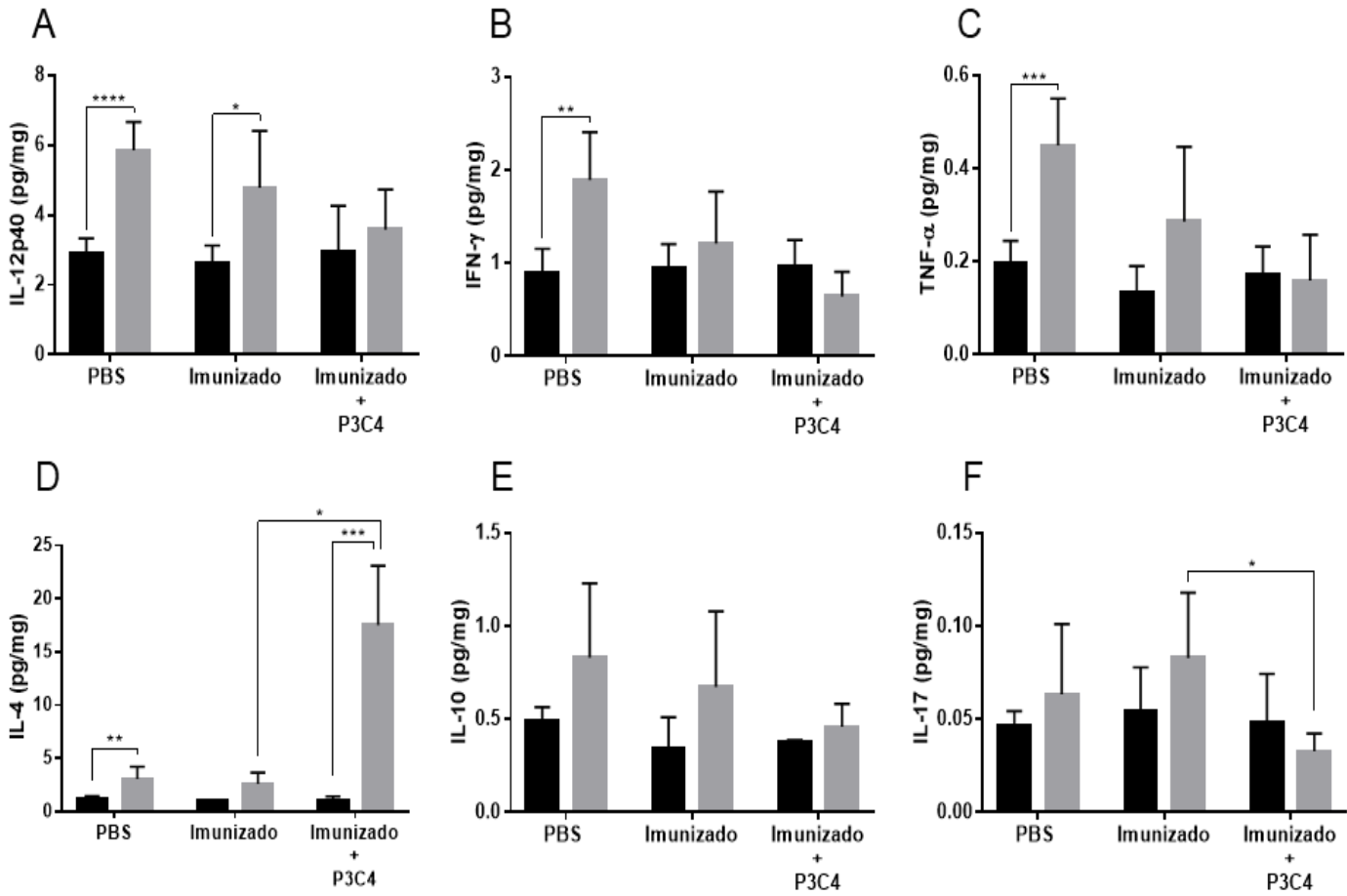

Figura 8. Níveis de citocinas no baço dos camundongos submetidos ao protocolo de imunização e avaliados nos dias 14 e 21 pós-imunização. Os pulmões dos animais foram coletados e homogeneizados e o sobrenadante utilizado na quantificação das citocinas (A) IL-12-p40, (B) IFN- $\gamma$, , (C) TNF- $\alpha$, (D) IL-4, (E) IL-10 e (F) IL-17 através de ELISA. Essa análise foi realizada após 14 dias (barra preta) e 21 dias (barra cinza) da etapa de imunização. A concentração das citocinas em $\mathrm{pg} / \mathrm{mL}$ foi normalizada em relação a massa do órgão $(\mathrm{mg})$ resultando na unidade $\mathrm{pg} / \mathrm{mg}$. Os valores foram expressos como média $\pm \mathrm{DP}$, e a diferença entre os grupos considerada significativa quando $\mathrm{p}<0,05(*), \mathrm{p}<0,01(* *), \mathrm{p}<0,001(* * *), \mathrm{p}<0,00001$ $(* * * *)$.

\subsubsection{Capacidade responsiva de células esplênicas obtidas de camundongos imunizados em reposta à incubação com $C$. gattii}

No sentido de complementar os achados de que os animais após imunização com leveduras inativadas de $C$. gattii em associação com a administração de Pam3CSk4 não resultou em um perfil citocínico Th1 e/ou Th17 predominante nos tecidos pulmonar e esplênico, averiguamos a capacidade responsiva das células esplênicas oriundas de camundongos imunizados. As células foram obtidas dos animais após 14 e 21 dias de imunização nos distintos grupos e incubadas na presença de LPS $(0,1 \mu \mathrm{g} / \mathrm{mL})$ ou $C$. gattii ( $2 \times 10^{6}$ células $\left./ \mathrm{mL}\right)$, e após $18 \mathrm{~h}$ de cultivo celular os níveis de TNF- $\alpha$ produzidos pelas células esplênicas foram quantificados no sobrenadante por ELISA. Na análise da resposta das células esplênicas referentes ao $14^{\circ}$ dia pós-imunização, os níveis de TNF- $\alpha$ 
estavam aumentados nos grupos PBS e Imunizado na presença de LPS comparado com as células não estimuladas (Figura 9A). Já as células esplênicas obtidas no $21^{\circ}$ dia pósimunização apresentaram uma elevação significativa nos níveis de TNF- $\alpha$ em todos os grupos na presença de LPS (Figura 9B). Além disso, as células esplênicas obtidas dos animais do grupo Imunizado+P3C4 produziram níveis significativamente aumentados de TNF- $\alpha$ em comparação ao grupo Imunizado, após estímulo com LPS (Figura 9B).

$\mathrm{Na}$ outra abordagem, as células esplênicas oriundas de camundongos após 14 e 21 dias de imunização, conforme protocolo de imunização descrito, foram co-cultivadas com leveduras de C. gattii. Após 18 h de cultivo celular, os níveis de TNF- $\alpha$ produzidos pelas células esplênicas estavam significativamente aumentados nas células obtidas no $21^{\circ}$ pósimunização comparado ao $14^{\circ}$ dia pós-imunização (Figura 9C). Porém, as células esplênicas obtidas dos grupos Imunizado e Imunizado+P3C4 na presença de C. gattii produziram níveis de TNF- $\alpha$ que não diferiram significativamente entre os grupos, para ambos os períodos avaliados pós-imunização (Figura 9C). Podemos concluir que a administração de Pam3CSk4 associada ao inóculo de leveduras inativadas de C. gattii não intensificou a capacidade responsiva de células esplênicas frente a infecção in vitro com C. gattii.
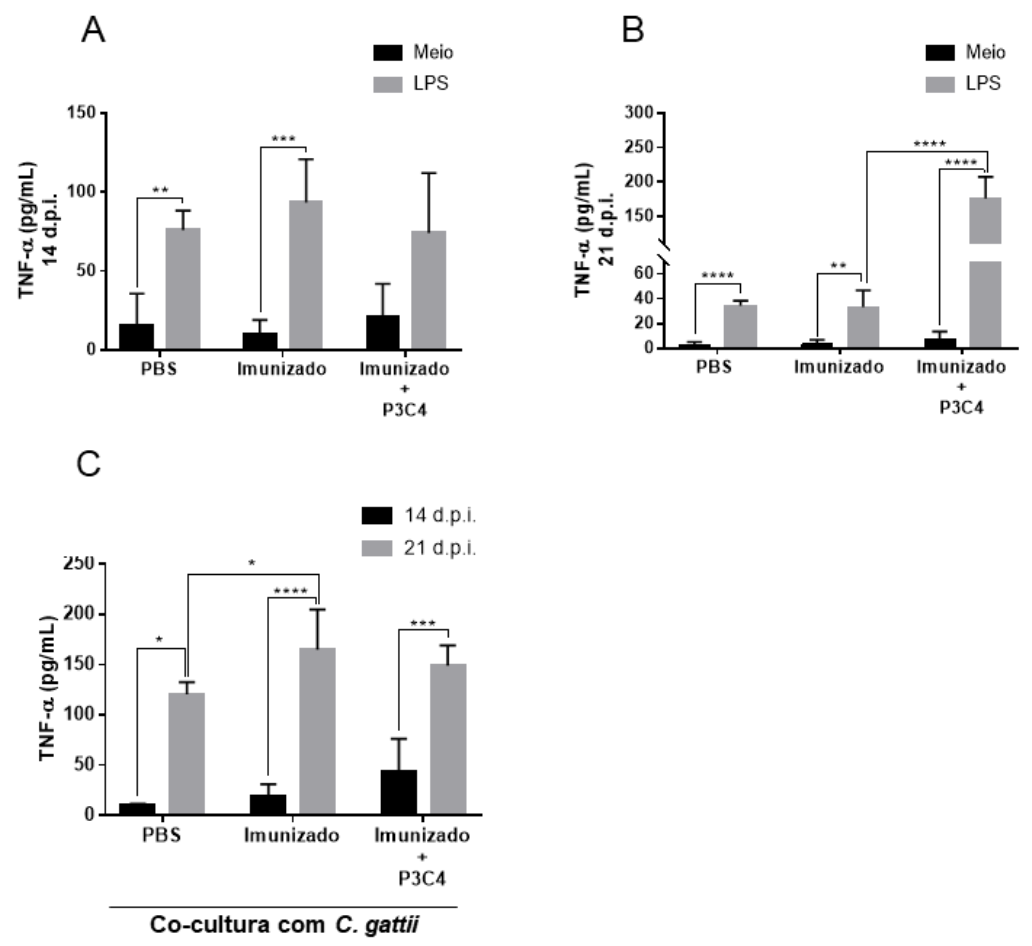

Figura 9. Níveis de TNF- $\alpha$ produzidos por células esplênicas de camundongos imunizados, obtidas nos dias 14 e 21 pós-imunização, após a incubação com LPS ou $C$. gattii. Células esplênicas (1x10 células/mL) de camundongos imunizados com leveduras inativadas de $C$. gattii em associação ou não 
(Imunizados) com a administração de Pam3CSk4 (Imunizado+P3C4) foram obtidas nos períodos de 14 dias pós-imunização-d.p.i. (A, C) e 21 dias pós-imunização-d.p.i. (B, C). As células esplênicas $\left(1 \times 10^{5}\right.$ células $/ \mathrm{mL})$ foram estimuladas ou não com $0,1 \mu \mathrm{g} / \mathrm{mL}$ de LPS $(\mathbf{A}, \mathbf{B})$ ou co-cultivadas com $C$. gattii $\left(2 \times 10^{6}\right.$ células $/ \mathrm{mL}$ ) (C) e, após $18 \mathrm{~h}$ de incubação, o sobrenadante foi coletado para a quantificação de TNF- $\alpha$ por ELISA. Os valores foram expressos como média $\pm \mathrm{DP}$, com $\mathrm{p}<0,05\left(^{*}\right)$ para diferença significativa.

\subsection{Avaliação da eficácia do protocolo de imunização no controle da infecção por C. gattii em camundongos BALB/c}

\subsubsection{Mensuração da carga fúngica pulmonar e análise da sobrevida dos animais submetidos ao protocolo de imunização e infectados com $C$. gattii}

Os animais dos grupos Imunizado e Imunizado+P3C4 tiveram níveis de citocinas no tecido pulmonar e uma capacidade responsiva das células esplênicas mais pronunciado no dia 21 pós-imunização em comparação aos mesmos dados obtidos no dia 14 pósimunização, com isso, adotamos o dia 21 pós-imunização como período de escolha para proceder com a infecção por C. gattii. Assim, o protocolo de imunização foi aplicado e no dia 21 pós-imunização os animais foram infectados com C. gattii (1×10 leveduras) via intranasal e após 21 dias de infecção foi mensurada a carga fúngica pulmonar (Figura 10A), conforme Esquema 2, e determinada a curva de sobrevida dos animais (Figura 10B) durante 34 dias de infecção. O homogeneizado do pulmão foi utilizado no ensaio de CFU, e observamos que o grupo Imunizado+P3C4 não apresentou uma redução significativa da carga de $C$. gattii, comparado com o grupo Imunizado (Figura 10A). Além disso, a avaliação da curva de sobrevida dos animais infectados com C. gattii ocorreu por 34 dias e demonstrou que a taxa de sobrevida do grupo Imunizado+P3C4 não diferiu significativamente da sobrevida dos animais referente ao grupo Imunizado (Figura 10B). Esses dados em conjunto indicam que a imunomodulação causada pela administração de Pam3CSk4, como adjuvante, não foi eficaz em conter a progressão da infecção por $C$. gattii. 

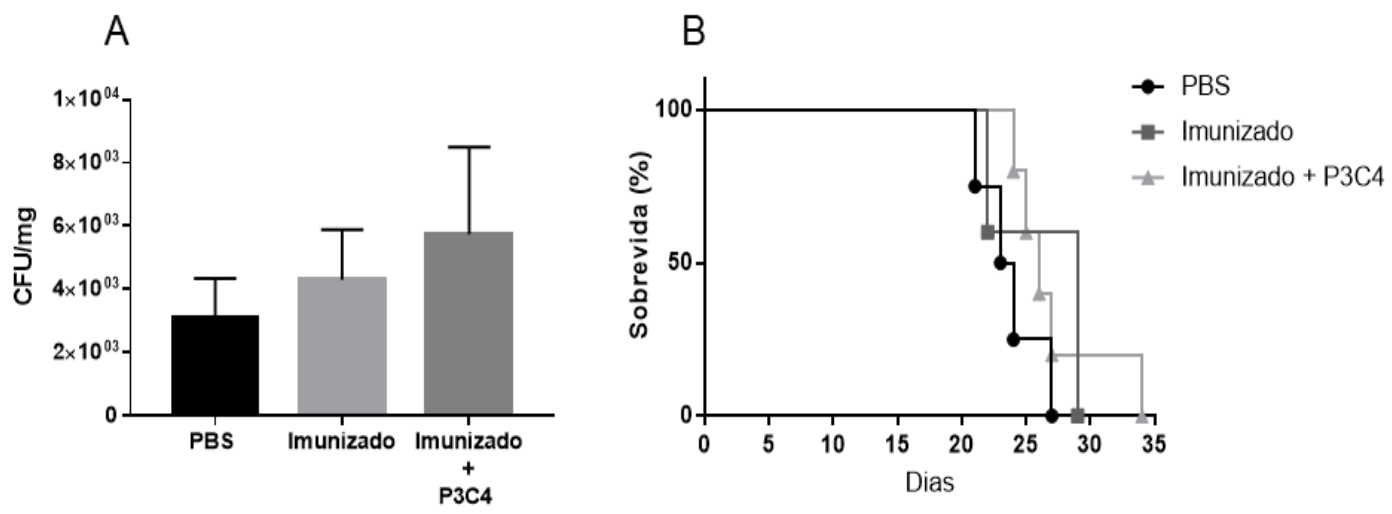

Figura 10. Carga fúngica pulmonar e curva de sobrevida dos camundongos submetidos a etapa de imunização seguido pela infecção com $\boldsymbol{C}$. gattii. Os animais, após os procedimentos de imunização de forma associada ou não (Imunizado) com Pam3CSk4 (Imunizado+P3C4), foram infectados com 1x10 leveduras de $C$. gattii no $21^{\circ}$ dia pós-imunização. (A) Após 21 dias de infecção, a carga fúngica foi quantificada a partir do homogeneizado do pulmão através de CFU (CFU/mg) realizado em ágar Sabouraud dextrose. (B) A curva de sobrevida foi feita diariamente por 34 dias e os resultados foram expressos em porcentagem $(\%)$ de sobrevida. Os valores foram expressos como média $\pm \mathrm{DP}$, com $\mathrm{p}<0,05\left(^{*}\right)$ para diferença significativa. 


\section{Capítulo III}

Título: Administração de Pam3CSk4 em estratégia vacinal contra a infecção por Cryptococcus gattii em camundongos C57BL/6 - Protocolo B 


\subsection{Avaliação da eficácia do protocolo de imunização no controle da infecção por C. gattii em camundongos C57BL/6}

O protocolo A de imunização avaliado em camundongos BALB/C (Esquemas 1 e 2) demonstrou que a imunomodulação causada por Pam3CSk4, utilizado como adjuvante nessa estratégia vacinal, não direcionou a uma resposta imunitária eficaz para conter a progressão da infecção por $C$. gattii. Portanto, o protocolo de imunização A foi modificado com a principal alteração no período relacionado a etapa de imunização que foi prolongado, e a geração do protocolo de imunização B (Esquema 3) considerou um estudo prévio de Yina Wung et al. (Yina Wung et al., 2019). Além disso, o protocolo de imunização B avaliou a administração de duas concentrações diferentes de Pam3CSk4, sendo $1 \mu \mathrm{g}$ e $10 \mu \mathrm{g}$, de forma associada com as leveduras inativadas de C. gattii (Esquema $3)$.

\subsubsection{Quantificação dos níveis séricos de IgG e IgM anti-GXM em camundongos submetidos à estratégia vacinal}

Os camundongos C57BL/6 foram imunizados com leveduras inativadas de $C$. gattii em associação com a administração de $1 \mu \mathrm{g}$ de Pam3CSk4 conforme detalhado no Esquema 3, e o soro foi obtido nos dias 7 e 14 após a última imunização. Os níveis séricos dos isotipos IgG e IgM específicos para GXM foram quantificados através de ELISA expressando os valores em absorbância (DO- densidade óptica), e os níveis de IgG antiGXM no grupo Imunizado + P3C4 não apresentaram diferenças significativas comparado com os grupos Imunizado e PBS (Figura 11A). Os níveis séricos de IgM anti-GXM foram determinados no $14^{\circ}$ dia pós-imunização a partir de cinco diluições (título 1:10, 1:20, 1:40, 1:80 e 1:160), e os níveis de IgM anti-GXM não diferiu significativamente entre os grupos em estudo (Figura 11B). Os dados em conjunto demonstram que a administração de $1 \mu \mathrm{g}$ de Pam3CSk4, como adjuvante, foi ineficaz na indução de elevados níveis séricos de anticorpos específicos para GXM, como avaliado previamente no período pósimunização. 

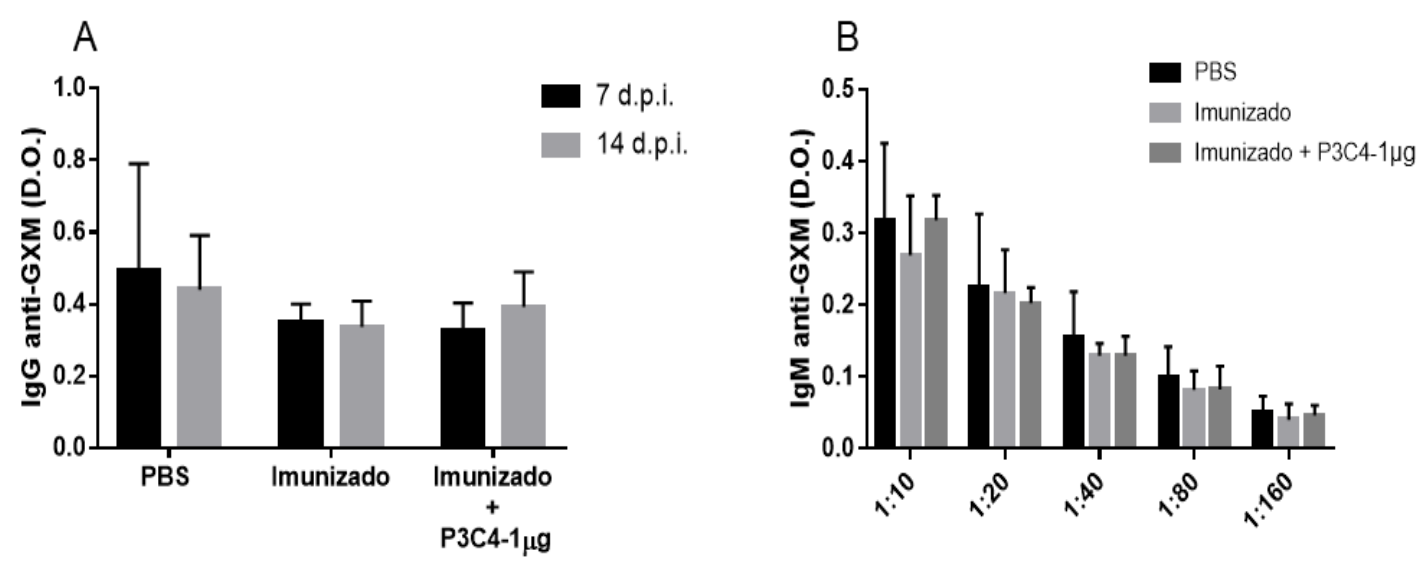

Figura 11. Quantificação de IgG e IgM anti-GXM no soro de camundongos nos períodos de 7 e/ou 14 dias pós-imunização a partir da estratégia vacinal. $O$ soro dos animais imunizados com leveduras inativadas de $C$. gattii de forma associada ou não com Pam3CSk4 $(1 \mu \mathrm{g})$ foi obtido nos dias 7 e/ou 14 pósimunização para determinar os níveis de $\operatorname{IgG}(\mathbf{A})$ e $\operatorname{IgM}(\mathbf{B})$ anti-GXM por ELISA. O soro utilizado na quantificação de IgG anti-GXM teve uma dilução 1:500 (A), e o soro na dosagem de IgM anti-GXM teve diluições seriadas 1:10, 1:20, 1:40, 1:80 e 1:160 (B). Os valores de absorbância (D.O.) foram utilizados para plotar o gráfico. Os animais que receberam PBS durante as etapas de imunização são considerados como grupo controle. Os valores foram expressos como média \pm DP.

\subsubsection{Isotipagem de imunoglobulinas no soro de camundongos submetidos a estratégia vacinal}

Para avaliarmos o efeito de Pam3CSk4, como adjuvante, na montagem de uma resposta imune adaptativa e/ou humoral em animais infectados com C. gattii, mensuramos os níveis séricos das imunoglobulinas IgG1, IgG2a, IgG2b, IgG3, IgA, IgM e cadeias Kappa e Lambda. Os animais C57BL/6 foram imunizados com leveduras inativadas de $C$. gattii de forma associada ou não com Pam3CSk4 (1 $\mu$ g ou $10 \mu \mathrm{g})$ e o soro foi obtido após 14 dias de infecção por $C$. gattii. Observamos uma redução nos níveis de absorbância para os isotipos IgG1 (Figura 12A), IgG2a (Figura 12B) e IgA (Figura 12E) nos camundongos que foram imunizados e receberam a administração de $1 \mu \mathrm{g}$ de Pam3CSk4 (Imunizado+P3C4), como adjuvante, comparado com o grupo Imunizado. Além disso, a quantificação dos níveis dos isotipo $\operatorname{IgG} 2 b$, IgG3, IgM e cadeias Kappa e Lambda não apresentaram alterações significativas entre os grupos em estudo (Figura 12). Já em relação aos camundongos que foram imunizados em associação com a administração de $10 \mu \mathrm{g}$ de Pam3CSk4 tiveram um aumento no nível de absorbância para cadeia leve Kappa, comparado com o grupo Imunizado (Figura 13G). Portanto, a administração de $1 \mu \mathrm{g}$ de Pam3CSk4 no contexto do protocolo de imunização compromete a manutenção dos níveis de isotipos de imunoglobulinas relacionadas com a resposta de anticorpos frente a componentes polissacarídeos de patógenos. 

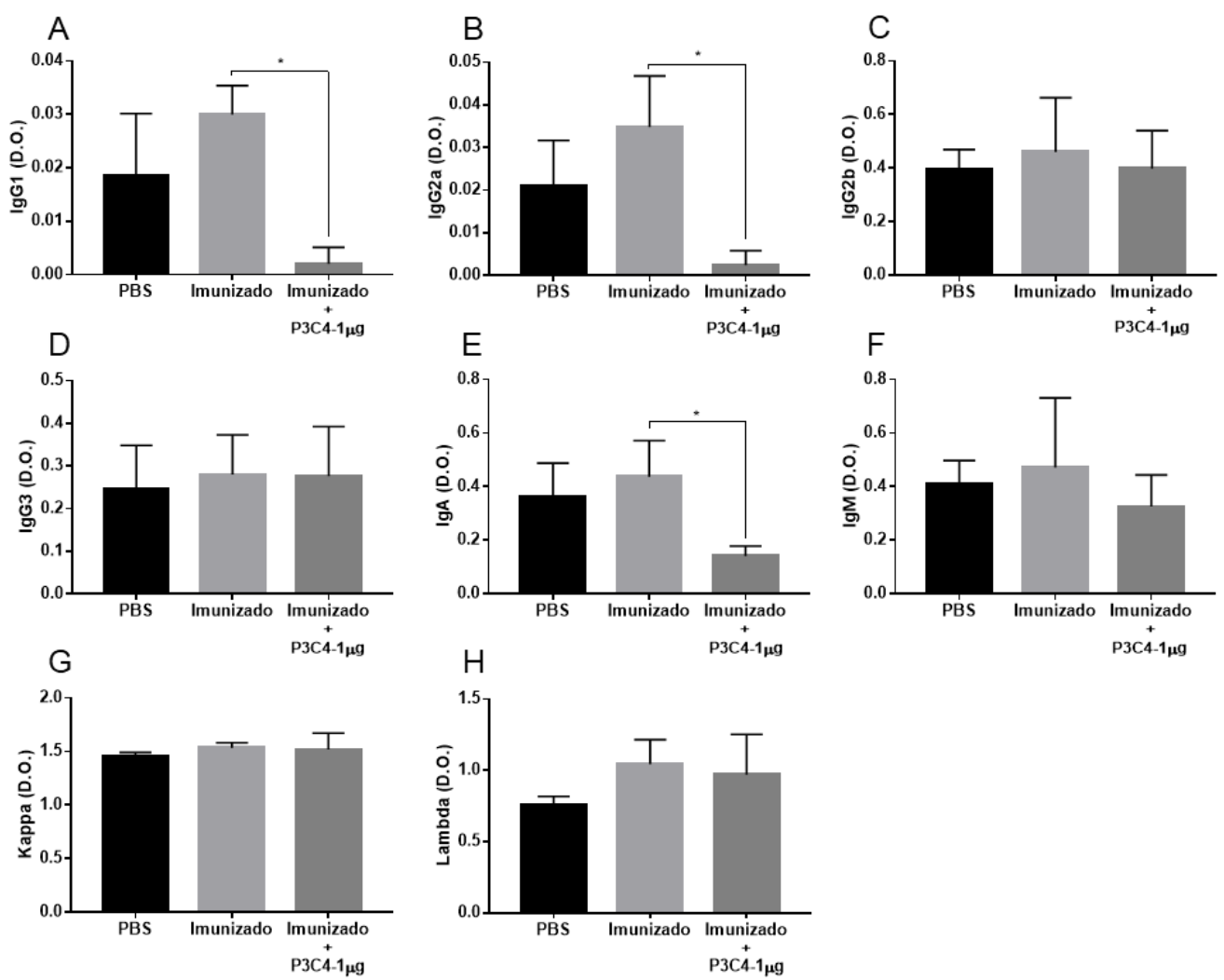

Figura 12. Isotipagem de imunoglobulinas séricas de camundongos imunizados em associação com 1 $\boldsymbol{\mu g}$ de Pam3CSk4 após infecção por $\boldsymbol{C}$. gattii. O soro dos animais foi obtido 14 dias após a infecção por C. gattii e diluído para determinar os níveis dos isotipos das imunoglobulinas (A) IgG1 (1:10000), (B) $\operatorname{IgG2a}(1: 10000)$, (C) $\operatorname{IgG} 2 b$ (1:40000), (D) $\operatorname{IgG} 3$ (1:10000), (E) $\operatorname{IgA}(1: 100),(\mathbf{F}) \operatorname{IgM}(1: 10000)$ e cadeias (G) Kappa (1:40000) e (H) Lambda (1:10000) nos grupos PBS, Imunizado e Imunizado+Pam3CSk4-1 $\mu$ g, através do kit EasyTiter ${ }^{\mathrm{TM}}$ Mouse IgG Assay (ThermoFischer) por ELISA. Os resultados foram expressos em absorbância (D.O.) após leitura em comprimento de onda de $450 \mathrm{~nm}$, e os valores estão representados em média \pm DP. 

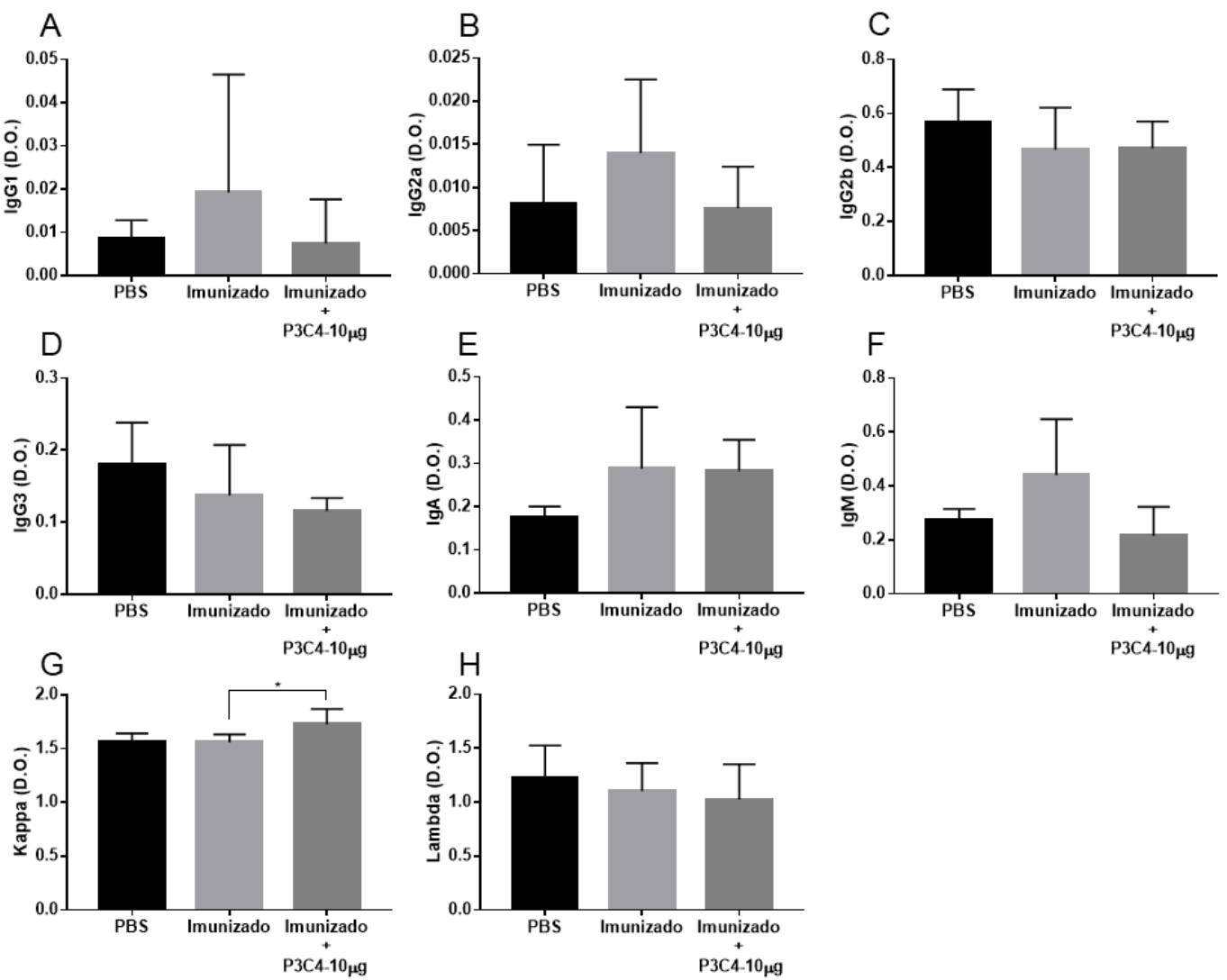

Figura 13. Isotipagem de imunoglobulinas séricas de camundongos imunizados em associação com $10 \mu$ ge Pam3CSk4 após infecção por $\boldsymbol{C}$. gattii. O soro dos animais foi obtido 14 dias após a infecção por C. gattii e diluído para determinar os níveis dos isotipos das imunoglobulinas (A) IgG1 (1:10000), (B) IgG2a (1:10000), (C) IgG2b (1:40000), (D) IgG3 (1:10000), (E) IgA (1:100), (F) IgM (1:10000) e cadeias

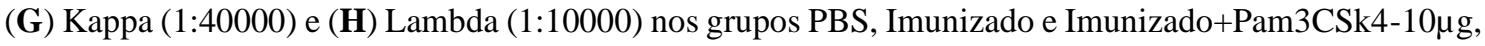
através do kit Easy Titer ${ }^{\mathrm{TM}}$ Mouse IgG Assay (ThermoFischer) por ELISA. Os resultados foram expressos em absorbância (D.O.) após leitura em comprimento de onda de $450 \mathrm{~nm}$, e os valores estão representados em média \pm DP.

\subsubsection{Níveis de citocinas no tecido pulmonar e no soro dos animais imunizados, associado com Pam3CSk4, e desafiados com $C$. gattii}

Para avaliar o possível efeito imunomodulador desencadeado pela etapa de imunização com leveduras inativadas de $C$. gattii, associada ou não com Pam3CSk4, no contexto da infecção por $C$. gattii, foi quantificado os níveis de citocinas no pulmão e no soro através de ELISA após 14 dias de infecção. O sobrenadante do homogeneizado do pulmão dos camundongos foi utilizado na quantificação dos níveis de IFN- $\gamma$, IL-12p70, TNF- $\alpha$, IL-1 $\beta$, IL-2, IL-17, IL-6, IL-10 e IL-4; enquanto os níveis de IFN- $\gamma$, IL-17 e IL4 foram mensurados no soro. A determinação do perfil de citocinas foi realizada para os protocolos de imunização que adotaram $1 \mu \mathrm{g}$ ou $10 \mu \mathrm{g}$ de Pam3CSk4 na associação com leveduras inativadas de $C$. gattii. A imunização com leveduras de $C$. gattii em associação com $1 \mu \mathrm{g}$ de Pam3CSk4 resultou em níveis de IFN- $\gamma$, IL-12p70, TNF- $\alpha$, IL-2, IL-6, IL- 
10 e IL-4 no tecido pulmonar sem alteração significativa comparado aos animais dos grupos Imunizado e PBS (Figura 14). Contudo, os animais do grupo Imunizado+P3C4 apresentaram níveis significativamente elevados das citocinas IL-1 $\beta$ (Figura 14D) e IL17 (Figura 14F) no tecido pulmonar em comparação a ambos os grupos, PBS e Imunizado. Já em relação aos níveis séricos de IFN- $\gamma$, IL-17 e IL-4 determinados nos distintos grupos, nenhuma alteração significativa foi detectada (Figura 15 A-C). Com isso, podemos inferir que a administração de $1 \mu \mathrm{g}$ de Pam3CSk4 associada a leveduras inativadas de C. gattii induziu uma imunomodulação no tecido pulmonar no período pósinfecção, com predomínio de citocinas envolvidas com o perfil Th17.
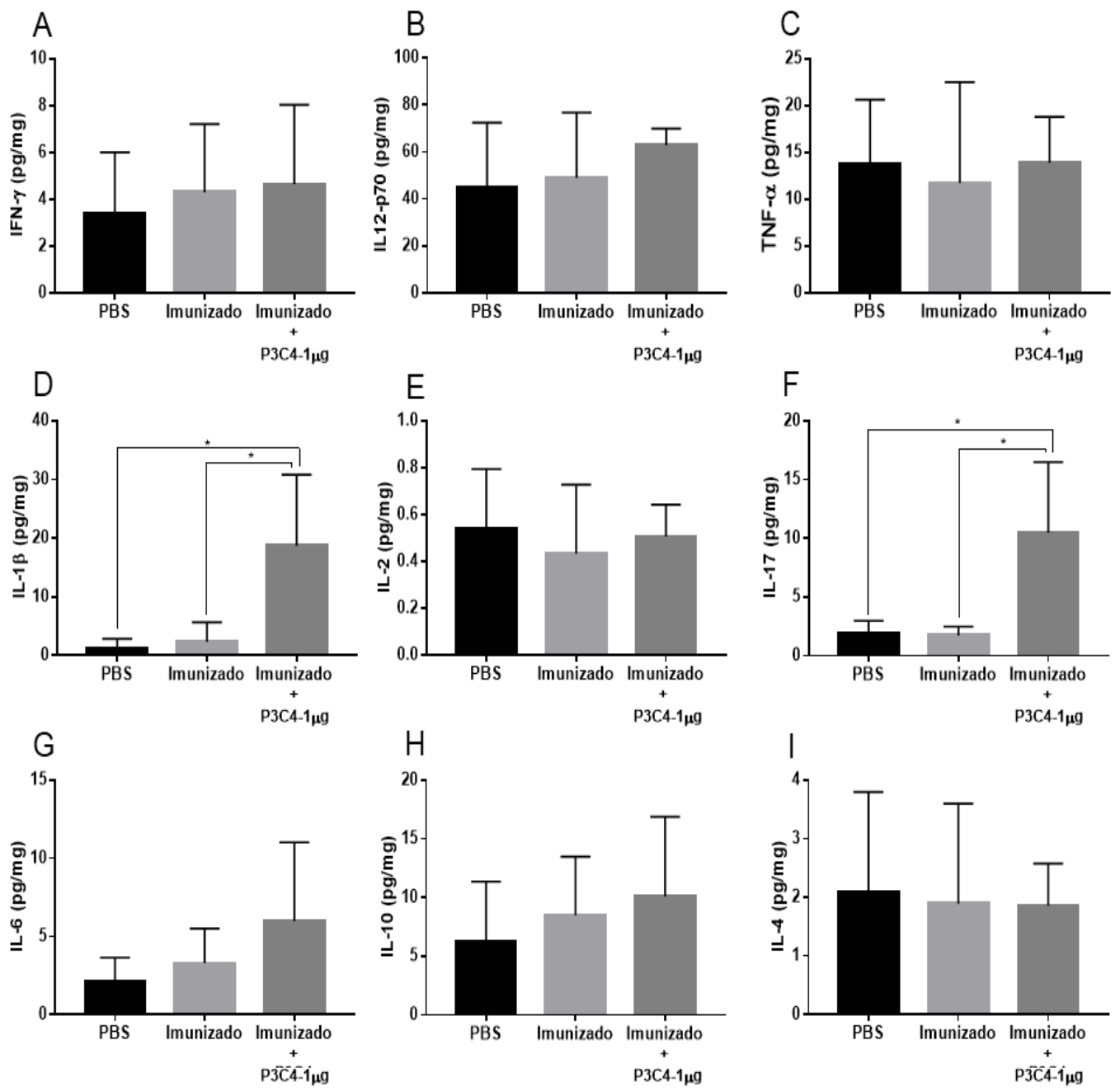

Figura 14. Níveis de citocinas no tecido pulmonar de camundongos imunizados com leveduras de $C$. gattii em associação com $1 \mu$ g de Pam3CSk4. Os camundongos foram submetidos a etapa de imunização com leveduras inativadas de $C$. gattii, associado ou não (Imunizado) com $1 \mu \mathrm{g}$ de Pam3CSk4 (Imunizado+P3C4-1 $\mu \mathrm{g}$ ), e infectados no $14^{\circ}$ dia pós-imunização. Após 14 dias de infecção por C. gattii, o pulmão dos animais foi coletado e homogeneizado, e o sobrenadante utilizado na quantificação das citocinas (A) IFN- $\gamma$, (B) IL-12p70, (C) TNF- $\alpha$, (D) IL-1 $\beta$, (E) IL-2, (F) IL-17, (G) IL-6, (H) IL-10 e (I) IL-4 através de ELISA. A concentração das citocinas em $\mathrm{pg} / \mathrm{mL}$ foi normalizada em relação a massa do 
órgão (mg) resultando na unidade $\mathrm{pg} / \mathrm{mg}$. Os valores foram expressos como média $\pm \mathrm{DP}$, e a diferença significativa em relação ao grupo controle quando $\mathrm{p}<0,05(*)$.
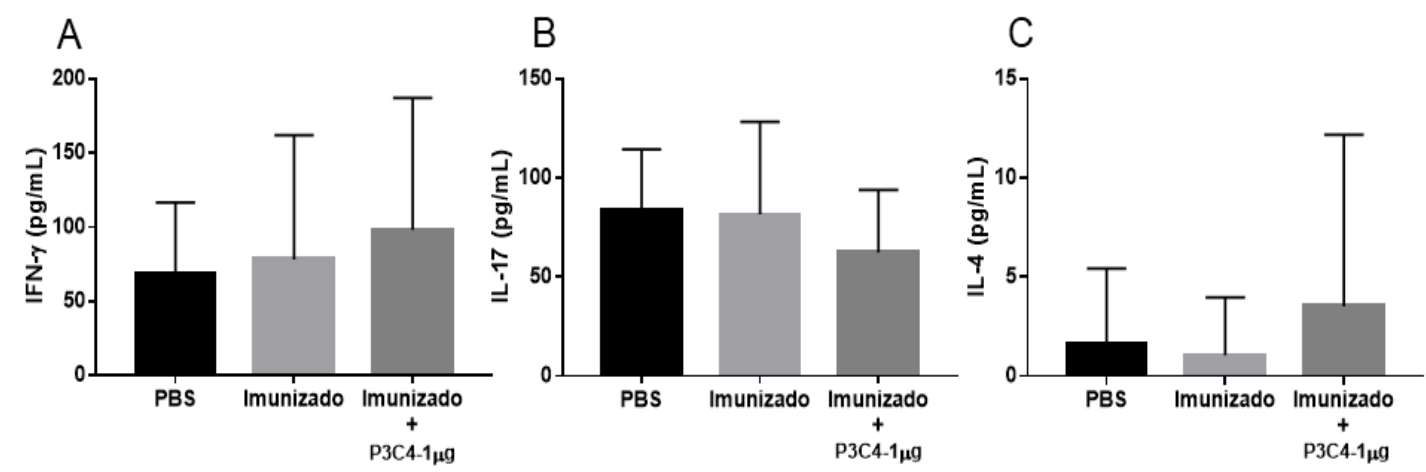

Figura 15. Níveis séricos de citocinas em camundongos imunizados com leveduras de $C$. gattii em associação com $1 \mu \mathrm{g}$ de Pam3CSk4. Os camundongos foram submetidos a etapa de imunização com leveduras inativadas de $C$. gattii, associado ou não (Imunizado) com $1 \mu \mathrm{g}$ de Pam3CSk4 (Imunizado+P3C4$1 \mu \mathrm{g})$, e infectados no $14^{\circ}$ dia pós-imunização. Após 14 dias de infecção por $C$. gattii, o soro dos animais foi obtido e utilizado para quantificação das citocinas (A) IFN- $\gamma$, (B) IL-17 e (C) IL-4 através de ELISA. A concentração das citocinas foi expressa em pg/mL. Os valores foram expressos como média \pm DP.

Em relação aos animais submetidos ao protocolo de imunização com leveduras inativadas de $C$. gattii associada a administração de $10 \mu \mathrm{g}$ de Pam3CSk4, os níveis de TNF- $\alpha$, IL-1 $\beta$, IL-2, e IL-4 no tecido pulmonar não tiveram significância comparado ao grupo Imunizado e PBS (Figura 16). Em contrapartida, os níveis de IFN- $\gamma$ (Figura 16A), IL-12p70 (Figura 16B), IL-6 (Figura 16G) e IL-10 (Figura 16H) detectados no tecido pulmonar do grupo Imunizado+P3C4 apresentaram uma redução significativa comparado ao grupo Imunizado, e o nível de IL-17 se manteve elevado no grupo Imunizado+P3C4 comparado aos animais somente Imunizados (Figura 16F). Assim como no protocolo de imunização que adota a administração de $1 \mu \mathrm{g}$ de Pam3CSk4, os níveis séricos de IFN- $\gamma$ e IL-17 não alteram significativamente entre os grupos (Figura 17A-B). Porém, o nível sérico de IL-4 se encontra elevado no grupo Imunizado+P3C4 em comparação ao grupo Imunizado (Figura 17C). Portanto, a administração de $10 \mu \mathrm{g}$ de Pam3CSk4 associada a leveduras inativadas de $C$. gattii regula negativamente as principais citocinas próinflamatórias no tecido pulmonar, mas o predomínio de altos níveis de IL-17 é mantido. 

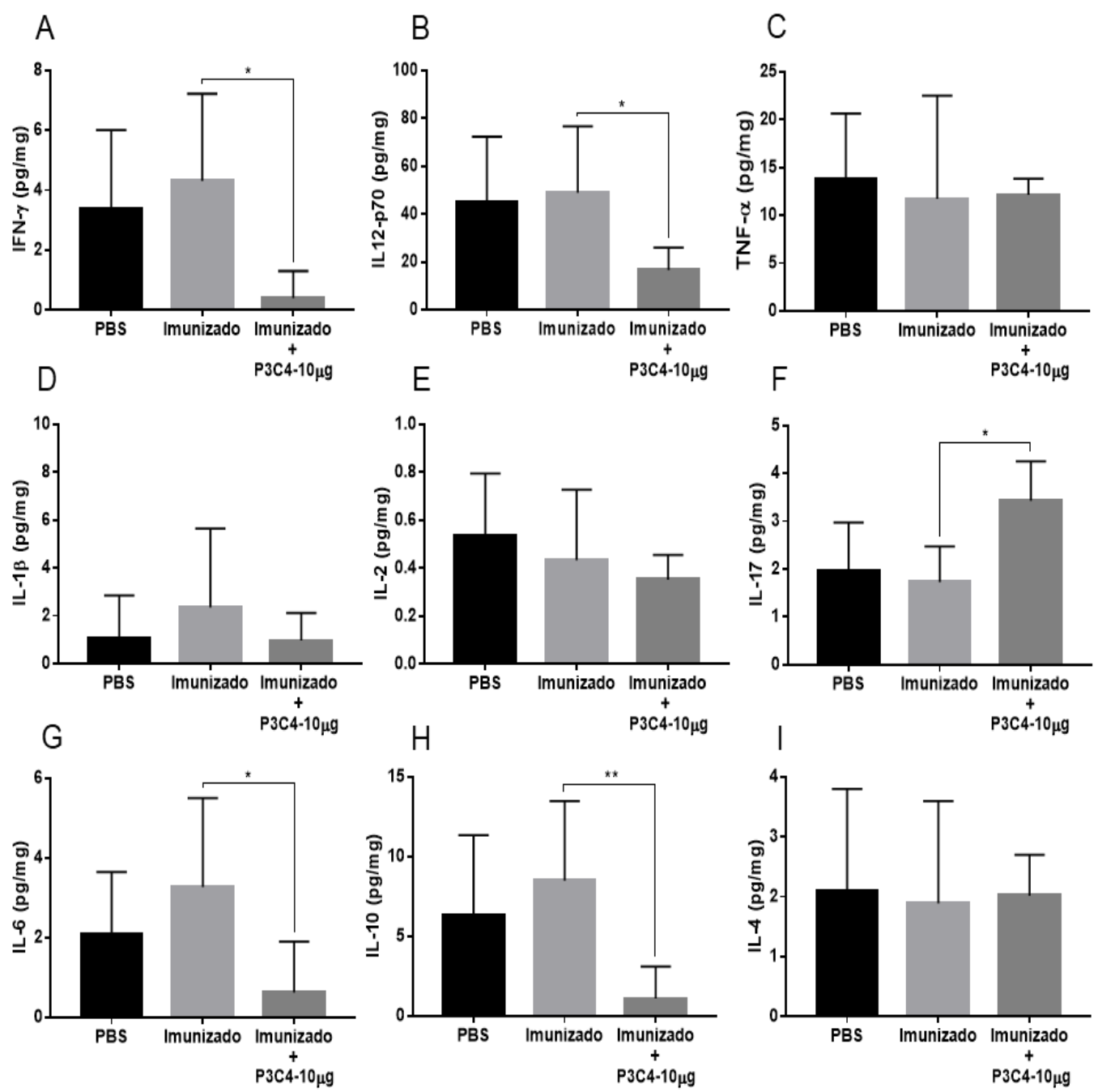

Figura 16. Níveis de citocinas no tecido pulmonar de camundongos imunizados com leveduras de $C$. gattii em associação com $10 \mu \mathrm{g}$ de Pam3CSk4 Os camundongos foram submetidos a etapa de imunização com leveduras inativadas de $C$. gattii, associado ou não (Imunizado) com $10 \mu \mathrm{g}$ de Pam3CSk4

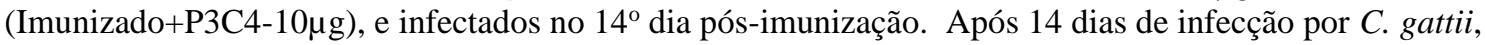
o pulmão dos animais foi coletado e homogeneizado, e o sobrenadante utilizado na quantificação das citocinas (A) IFN- $\gamma$, (B) IL-12p70, (C) TNF- $\alpha$, (D) IL-1 $\beta$, (E) IL-2, (F) IL-17, (G) IL-6, (H) IL-10 e (I) IL-4 através de ELISA. A concentração das citocinas em $\mathrm{pg} / \mathrm{mL}$ foi normalizada em relação a massa do órgão (mg) resultando na unidade $\mathrm{pg} / \mathrm{mg}$. Os valores foram expressos como média $\pm \mathrm{DP}$, e a diferença significativa em relação ao grupo controle quando $\mathrm{p}<0,05(*), \mathrm{p}<0,01(* *)$. 

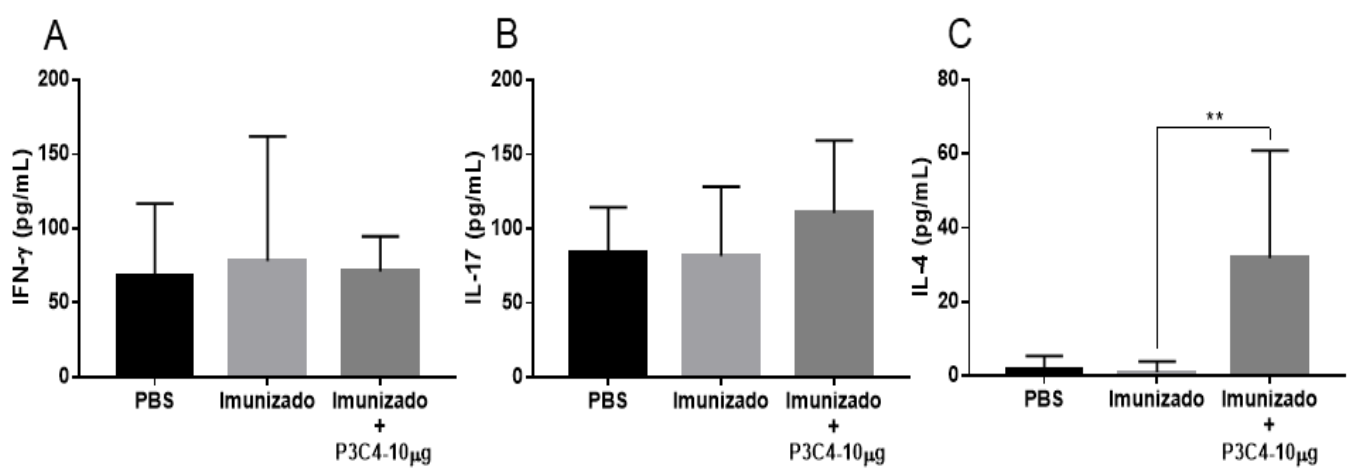

Figura 17. Níveis séricos de citocinas de camundongos imunizados com leveduras de $C$. gattii em associação com $10 \mu \mathrm{g}$ de Pam3CSk4. Os camundongos foram submetidos a etapa de imunização com leveduras inativadas de $C$. gattii, associado ou não (Imunizado) com $10 \mu \mathrm{g}$ de Pam3CSk4

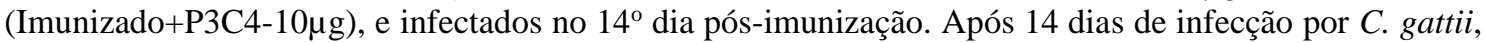
o soro dos animais foi obtido e utilizado na quantificação das citocinas (A) IFN- $\gamma$, (B) IL-17 e (C) IL-4 através de ELISA. A concentração das citocinas foi expressa em $\mathrm{pg} / \mathrm{mL}$. Os valores foram expressos como média \pm DP.

\subsubsection{Fenotipagem dos leucócitos pulmonares de camundongos imunizados, em associação com Pam3CSk4, e infectados com $C$. gattii}

Para dar continuidade na avaliação do efeito imunomodulador desencadeado pela etapa de imunização com leveduras inativadas de $C$. gattii, associada ou não com Pam3CSk4, propusemos verificar no tecido pulmonar dos animais imunizados o perfil fenotípico dos leucócitos pulmonares através de citometria de fluxo. Para isso, os leucócitos pulmonares foram obtidos no $14^{\circ}$ dia após a infecção por C. gattii, conforme especificado no Esquema 3, e avaliamos a frequência (\%) e a concentração de células positivas para os marcadores CD3/CD4, F4/80, CD11b, CD11c. Constatamos que os animais imunizados em associação com a administração de $1 \mu \mathrm{g}$ de Pam3CSk4 apresentaram uma frequência reduzida de células $\mathrm{F} 4 / 80^{+}$comparado com o grupo Imunizado (Figura 18C), enquanto a concentração de células $\mathrm{F} 4 / 80^{+}$se mantém inalterada entre os grupos. Na quantificação da frequência e concentração de células $\mathrm{CD} 3^{+} / \mathrm{CD} 4^{+}$, $\mathrm{CD}_{11 \mathrm{~b}^{+}}$e CD11c $\mathrm{c}^{+}$não observamos alterações significativas entre os grupos avaliados (Figura 18). Também mensuramos o nível de expressão do receptor TLR2 na superfície dos leucócitos pulmonares obtidos dos animais dos diferentes grupos e houve um aumento significativo na frequência de células TLR2 ${ }^{+}$visto no grupo Imunizado+P3C4 comparado ao grupo Imunizado (Figura 19A), porém essa alteração não se reproduziu na avaliação da concentração de células TLR2 ${ }^{+}$e na intensidade média de fluorescência de TLR2 na superfície celular (Figura 19B-D). 
A
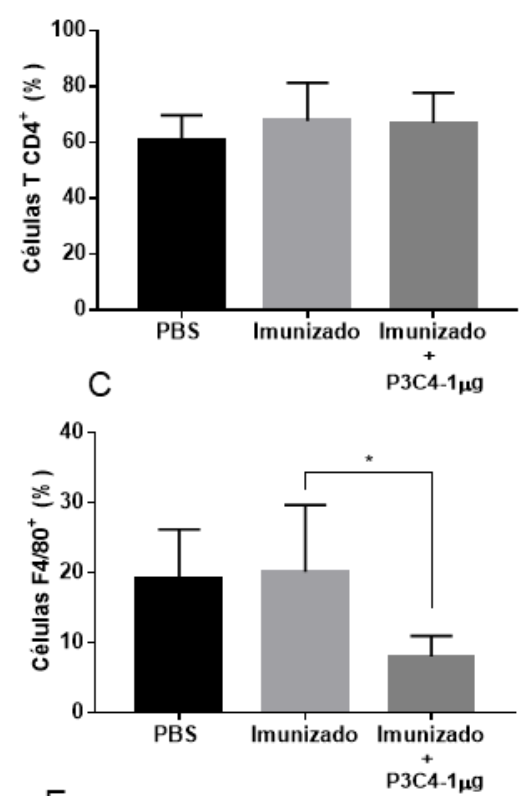

$\mathrm{E}$

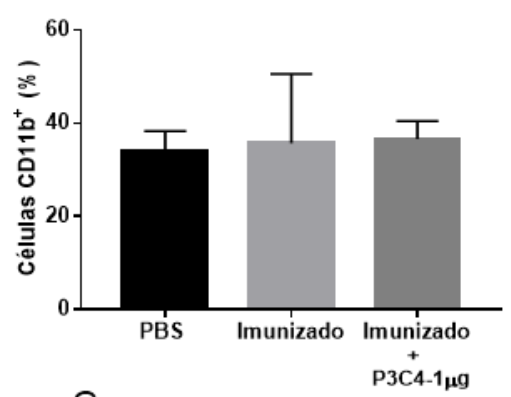

G

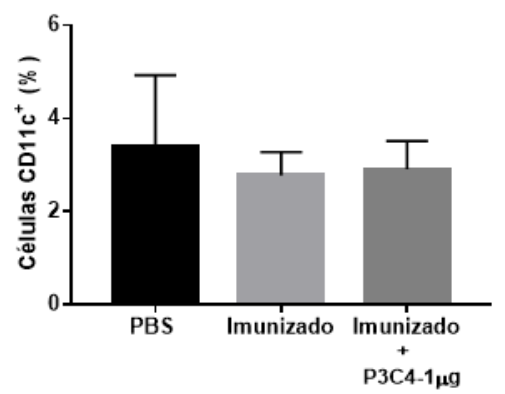

B
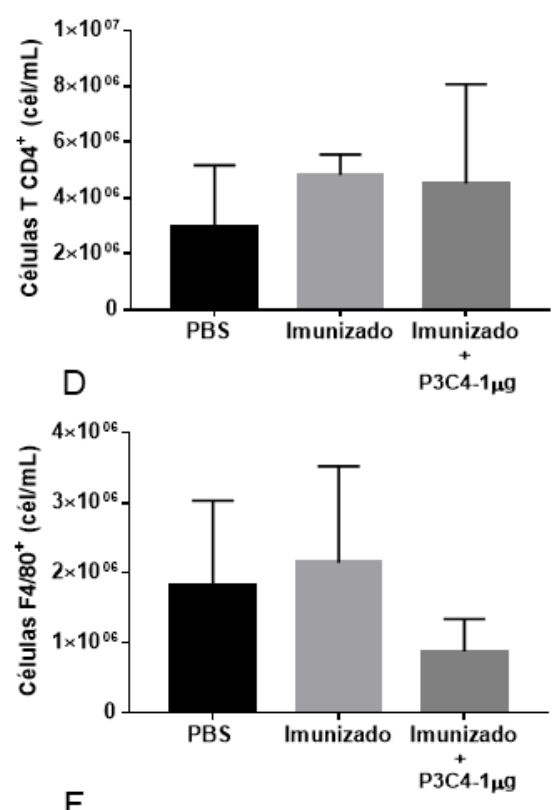

$\mathrm{F}$

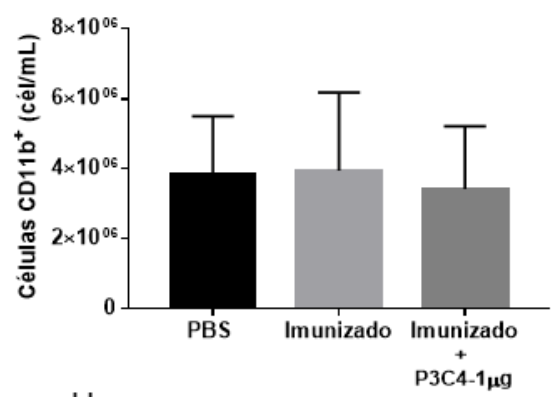

$\mathrm{H}$

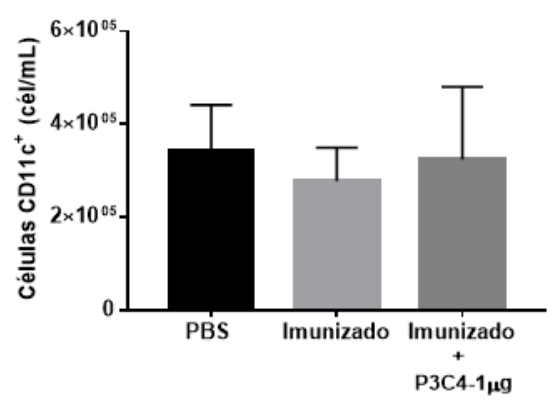

Figura 18. Fenótipo dos leucócitos pulmonares de camundongos imunizados em associação com $1 \boldsymbol{\mu g}$ de Pam3CSk4. Os animais foram submetidos a etapa de imunização com leveduras inativadas de $C$. gattii, associado ou não (Imunizado) com $1 \mu \mathrm{g}$ de Pam3CSk4 (Imunizado+P3C4-1 $\mu$ g), e o grupo PBS representa animais não imunizados. Esses camundongos foram infectados por $C$. gattii e após 14 dias de infecção, o pulmão dos animais foi coletado e utilizado na preparação da suspensão celular para fenotipagem dos leucócitos pulmonares através de citometria de fluxo. As células foram incubadas com os seguintes anticorpos monoclonais: anti-CD3 (PE-Cy5 Rat anti-Mouse CD3; clone 17A2; BD Pharmingen), anti-CD4 (FITC Rat anti-Mouse CD4; clone H129.19; BD Pharmingen), anti-F4/80 (FITC Rat anti-Mouse F4/80; clone BM8; BD Pharmingen), anti-CD11b (Alexa Fluor 488 Rat Anti-Mouse CD11b; clone M1/70; BD Pharmingen) e anti-CD11c (PE Hamster Anti-Mouse CD11c; clone HL3; BD Pharmingen). A frequência (\%) de células positivas no painel de marcação foi utilizado para calcular a concentração celular a partir da determinação prévia de células/mL na suspensão de leucócitos pulmonares. Os valores foram expressos como média $\pm \mathrm{DP}$, e a diferença significativa em relação ao grupo controle quando $\mathrm{p}<0,05(*)$. 

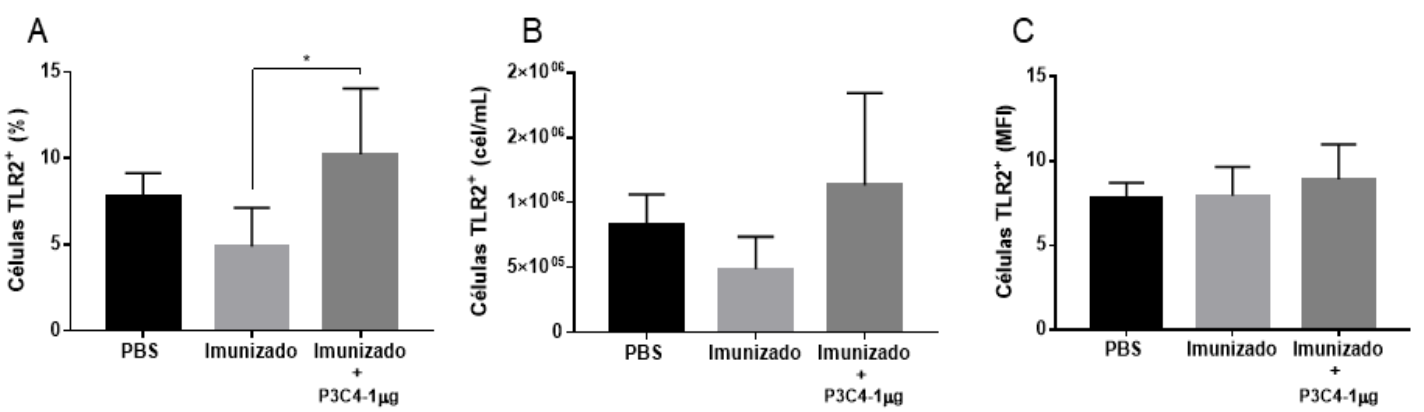

Figura 19. Expressão de TLR2 em leucócitos pulmonares de camundongos imunizados em associação com $1 \mu$ g de Pam3CSk4. Os animais foram submetidos a etapa de imunização com leveduras inativadas de $C$. gattii, associado ou não (Imunizado) com $1 \mu \mathrm{g}$ de Pam3CSk4 (Imunizado+P3C4-1 $\mu \mathrm{g}$ ), e o grupo PBS representa animais não imunizados. Esses camundongos foram infectados por $C$. gattii e após 14 dias de infecção, o pulmão dos animais foi coletado e utilizado na preparação da suspensão celular que foram incubadas com anticorpo monoclonal anti-TLR2-PE (PE Rat Anti-Mouse TLR2; clone 6C2; BD Pharmingen) para determinar por citometria de fluxo a (A) porcentagem celular, (B) concentração celular e (C) média da intensidade de fluorescência de células positivas para TLR2. A frequência (\%) de células positivas no painel de marcação foi utilizada para calcular a concentração celular a partir da determinação prévia de células $/ \mathrm{mL}$ na suspensão de leucócitos pulmonares. Os valores foram expressos como média \pm $\mathrm{DP}$, e a diferença significativa em relação ao grupo controle quando $\mathrm{p}<0,05(*)$.

Em um segundo momento, foi realizada a fenotipagem de células positivas para CD3, CD11c, Ly6G e F4/80 no tecido pulmonar de camundongos submetidos ao protocolo de imunização, associado ou não com $10 \mu \mathrm{g}$ de Pam3CSk4, e infectados com C. gattii. Após 14 dias de infecção, observamos que a frequência (\%) de células CD11c ${ }^{+}$ e F4/80 $0^{+}$no grupo PBS foi maior comparado ao grupo Imunizado, porém a frequência dos tipos celulares avaliados não diferiu significativamente no grupo Imunizado+P3C4 comparado aos grupos PBS e Imunizado (Figura 20C e G). Além disso, também quantificamos a frequência de células positivas para TLR2 e o nível de expressão desse receptor na superfície dos leucócitos pulmonares, e os animais do grupo imunizado em associação com $10 \mu \mathrm{g}$ de Pam3CSk4 não teve alterações significativas comparado aos demais grupos (Figura 21). 
A
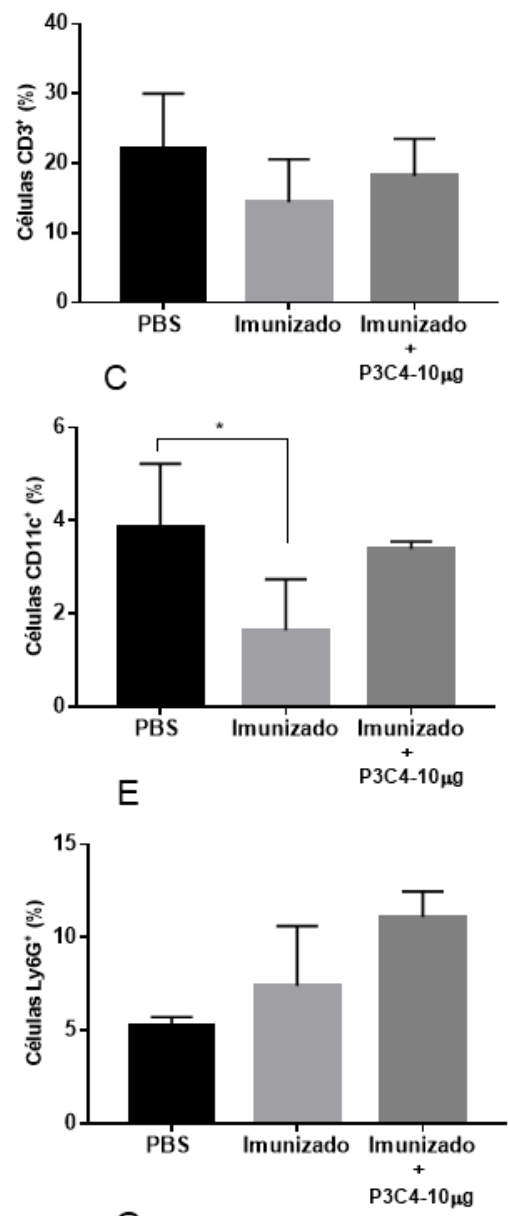

G

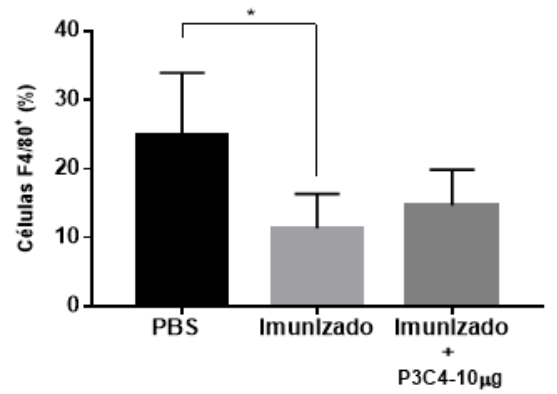

B
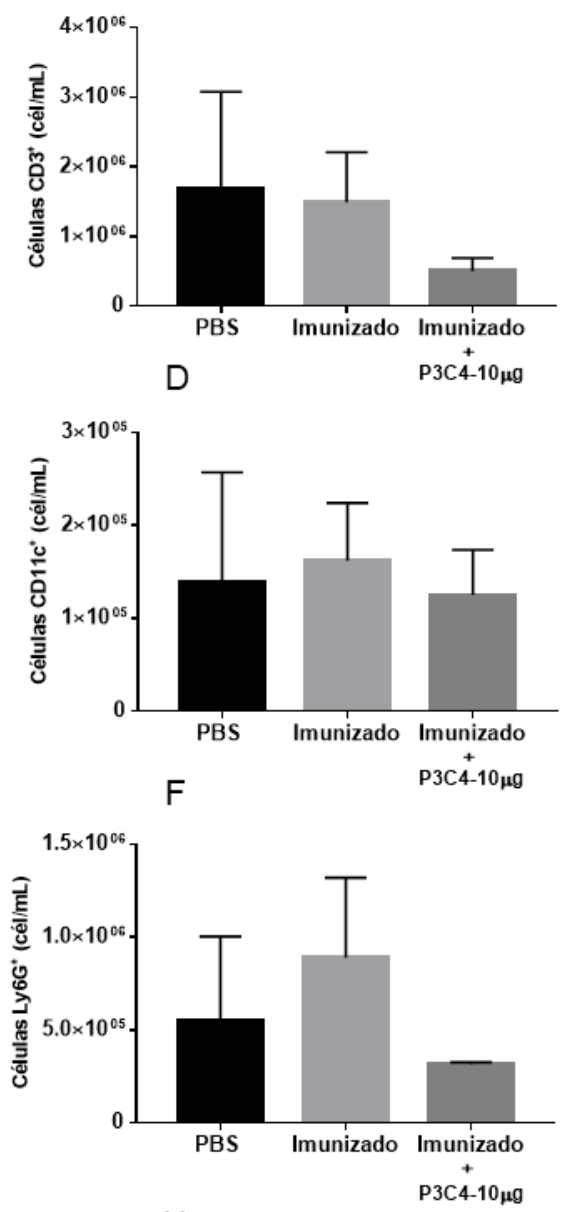

$\mathrm{H}$

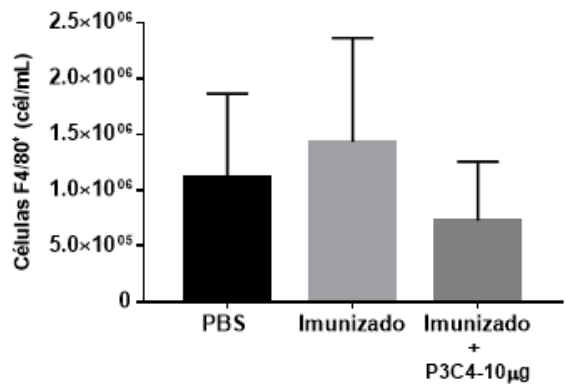

Figura 20. Fenótipo dos leucócitos pulmonares de camundongos imunizados em associação com 10 Mg de Pam3CSk4. Os animais foram submetidos a etapa de imunização com leveduras inativadas de $C$. gattii, associado ou não (Imunizado) com $10 \mu \mathrm{g}$ de Pam3CSk4 (Imunizado+P3C4-10 $\mu \mathrm{g}$ ), e o grupo PBS representa animais não imunizados. Esses camundongos foram infectados por $C$. gattii e após 14 dias de infecção, o pulmão dos animais foi coletado e utilizado na preparação da suspensão celular para fenotipagem dos leucócitos pulmonares através de citometria de fluxo. As células foram incubadas com os seguintes anticorpos monoclonais: anti-CD3 (PE-Cy5 Rat anti-Mouse CD3; clone 17A2; BD Pharmingen), anti- CD11c (PE Hamster Anti-Mouse CD11c; clone HL3; BD Pharmingen), anti-Ly-6G (PerCP-Cy ${ }^{\mathrm{TM}} 5.5$ Rat Anti-Mouse Ly-6G) e anti F4/80 (FITC Rat anti-Mouse F4/80; clone BM8; BD Pharmingen). A frequência (\%) de células positivas no painel de marcação foi utilizado para calcular a concentração celular a partir da determinação prévia de células/mL na suspensão de leucócitos pulmonares. Os valores foram expressos como média $\pm \mathrm{DP}$, e a diferença significativa em relação ao grupo controle quando $\mathrm{p}<0,05\left(^{*}\right)$. 
A

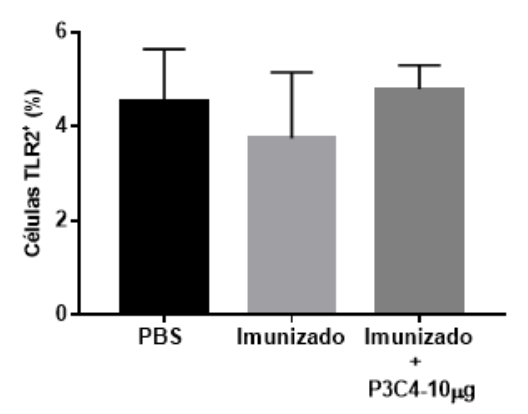

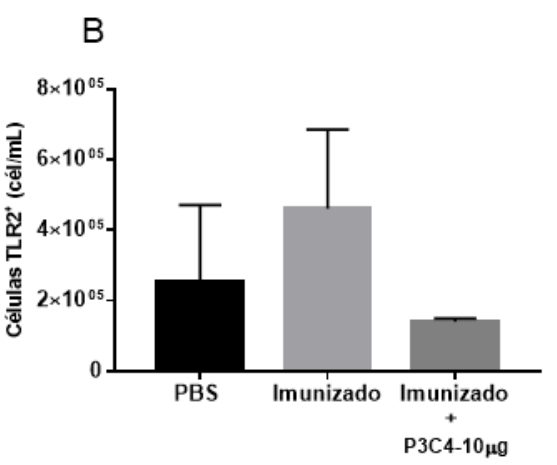

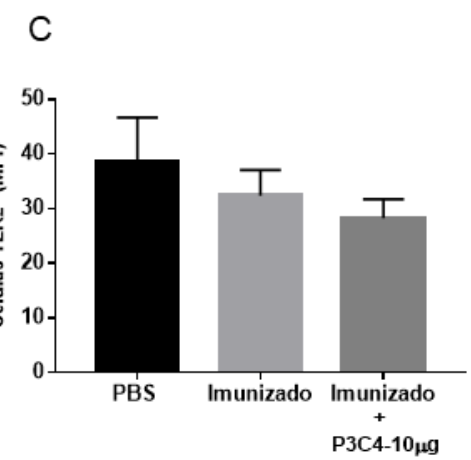

Figura 21. Expressão de TLR2 em leucócitos pulmonares de camundongos imunizados em associação com 10 Mg de Pam3CSk4. Os animais foram submetidos a etapa de imunização com leveduras inativadas

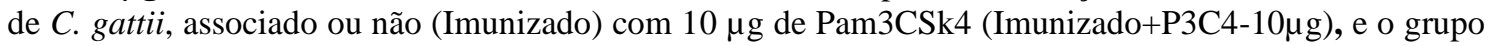
PBS representa animais não imunizados. Esses camundongos foram infectados por C. gattii e após 14 dias de infecção, o pulmão dos animais foi coletado e utilizado na preparação da suspensão celular que foram incubadas com anticorpo monoclonal anti-TLR2-PE (PE Rat Anti-Mouse TLR2; clone 6C2; BD Pharmingen) para determinar por citometria de fluxo a (A) porcentagem celular, (B) concentração celular e (C) média da intensidade de fluorescência de células positivas para TLR2. A frequência (\%) de células positivas no painel de marcação foi utilizado para calcular a concentração celular a partir da determinação prévia de células/mL na suspensão de leucócitos pulmonares. Os valores foram expressos como média \pm $\mathrm{DP}$, e a diferença significativa em relação ao grupo controle quando $\mathrm{p}<0,05(*)$.

\subsubsection{Perfil de células $\mathrm{T} \mathrm{CD}^{+}$e subtipos de macrófagos no tecido pulmonar de camundongos imunizados, em associação com Pam3CSk4, e infectados com C. gattii}

Para complementar o estudo do perfil de células da imunidade no tecido pulmonar em decorrência do protocolo de imunização associado ao efeito modulador de Pam3CSk4, buscamos caracterizar o perfil de células T CD4 e macrófagos diferenciados no tecido pulmonar induzido pela estratégia vacinal ao final do período de infecção com C. gattii. Realizamos a quantificação por qRT-PCR da expressão relativa dos transcritos dos principais marcadores de polarização de macrófagos para os subtipos M1 (iNOS, Figura 22A) e M2 (Arginase, Figura 22B); e também dos marcadores característicos de células Th1 (T-bet, Figura 22C), Th2 (GATA3, Figura 22 D), Th17 (ROR- $\gamma$ t Figura 22 E) e Treg (Foxp3, Figura 22F). Além disso, a expressão relativa dos transcritos referentes aos marcadores STAT (Figura 22G-I), IL-23 (Figura 22J) e TGF- $\beta$ (Figura 22K) foram quantificados para auxiliar na caracterização dos perfis de células T CD4 ${ }^{+}$. Em relação ao protocolo de imunização associado com a administração de $1 \mu \mathrm{g}$ de Pam3CSk4, verificamos uma redução da expressão relativa de T-bet no grupo Imunizado+P3C4 (Figura 22C) e um aumento da expressão relativa de Foxp3 no grupo Imunizado+P3C4 (Figura 22F), ambos comparados com o grupo Imunizado. Para os demais marcadores 
avaliados não foram encontradas alterações significativas (Figura 22). Na abordagem do protocolo de imunização acompanhado pela administração de $10 \mu \mathrm{g}$ de Pam3CSk4, a expressão relativa de STAT3 observado no grupo Imunizado+P3C4 foi reduzido em relação ao grupo PBS (Figura 23H). Podemos concluir que a administração de $1 \mu \mathrm{g}$ de Pam3CSk4 no contexto do protocolo de imunização propiciou um predomínio de células $\mathrm{T} \mathrm{CD} 4^{+}$reguladoras no tecido pulmonar.
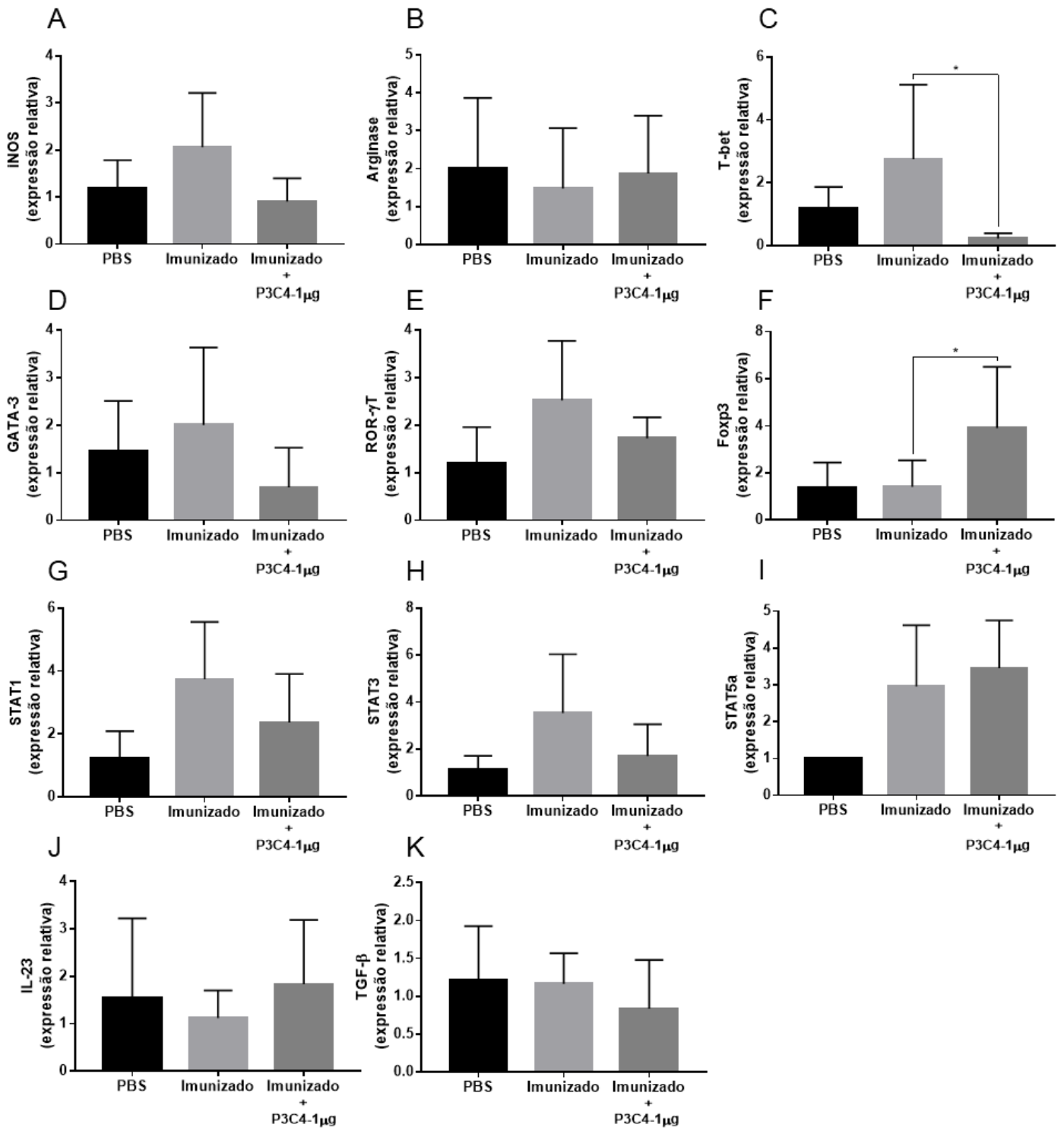

Figura 22. Polarização de macrófagos e diferenciação de células $\mathrm{T} \mathrm{CD4}^{+}$no tecido pulmonar de camundongos imunizados em associação com $1 \mu \mathrm{g}$ de Pam3CSk4. Os animais foram submetidos ao protocolo de imunização com a administração em conjunto de $1 \mu \mathrm{g}$ de Pam3CSk4 (Imunizado+P3C4) ou veículo (Imunizado), e o grupo PBS representa animais não imunizados. Após protocolo de imunização, os camundongos foram infectados com $C$. gattii e após 14 dias de infecção o pulmão dos animais foi coletado e utilizado na extração de RNA e posterior conversão em cDNA. A expressão relativa de (A) iNOS, (B) Arginase-1, (C) T-bet, (D) GATA3, (E) ROR- $\gamma$ t, (F) FOXP3, (G) STAT1, (H) STAT3, (I) STAT5a, (J) IL-23 e (K) TGF- $\beta$ foi determinada por qRT-PCR. Os valores de $\Delta \Delta$ Ct foram utilizados para determinar a expressão relativa tendo como controle endógeno o transcrito de $\beta$-actina. Os valores foram expressos como média $\pm \mathrm{DP}$, e a diferença significativa em relação ao grupo controle quando $\left.\mathrm{p}<0,05{ }^{*}\right)$. 

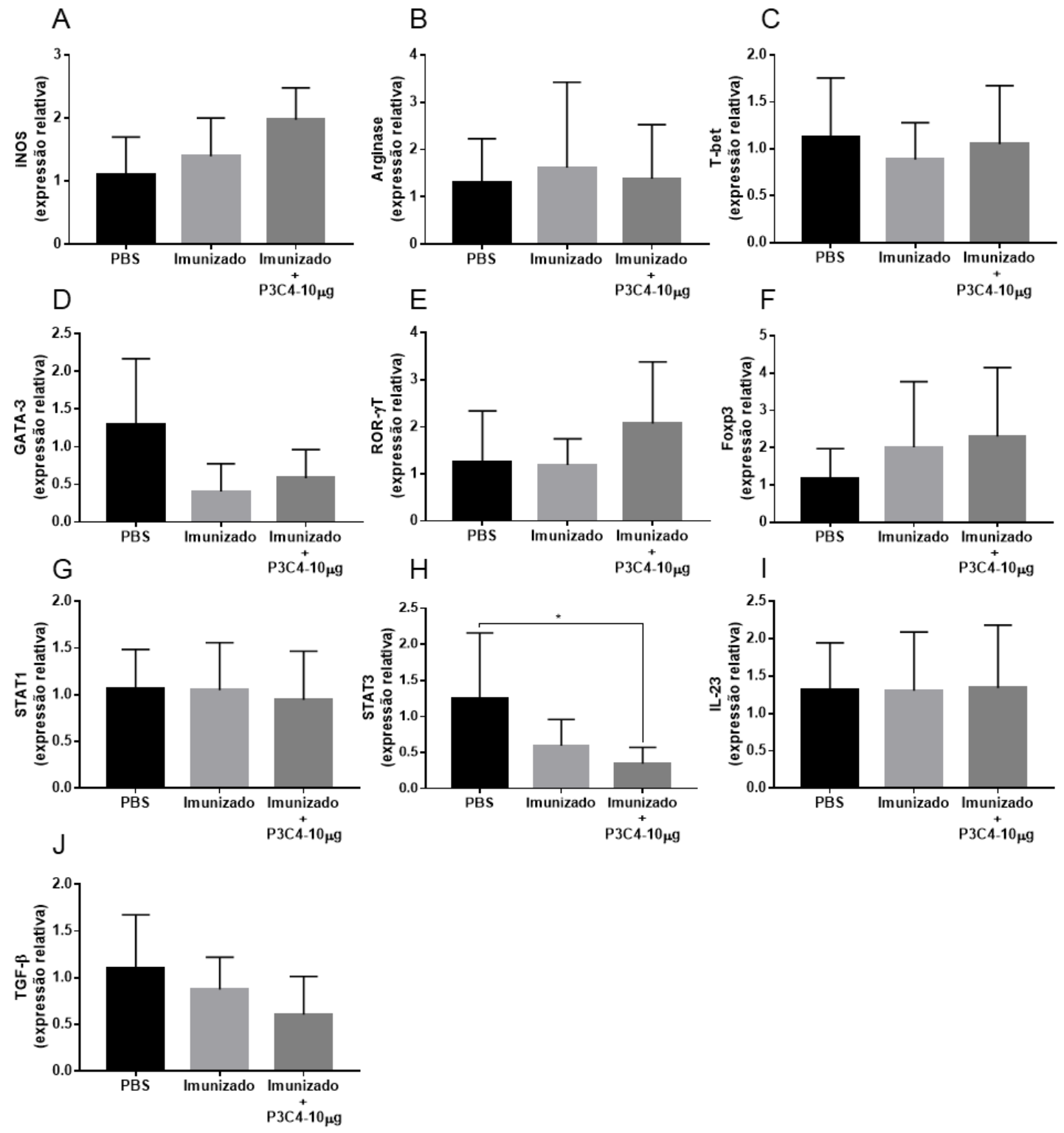

Figura 23. Expressão relativa de marcadores de diferenciação de macrófagos e células $\mathbf{T} \mathrm{CD4}^{+}$no tecido pulmonar de camundongos imunizados em associação com $10 \mu \mathrm{g}$ de Pam3CSk4. Os animais foram submetidos ao protocolo de imunização com a administração em conjunto de $10 \mu \mathrm{g}$ de Pam3CSk4 (Imunizado+P3C4) ou veículo (Imunizado), e o grupo PBS representa animais não imunizados. Após protocolo de imunização, os camundongos foram infectados com C. gattii e após 14 dias de infecção o pulmão dos animais foi coletado e utilizado na extração de RNA para conversão em cDNA. A expressão relativa de (A) iNOS, (B) Arginase-1, (C) T-bet, (D) GATA3, (E) ROR- $\gamma$ t, (F) FOXP3, (G) STAT1, (H) STAT3, (I) IL-23 e (J) TGF- $\beta$ foi determinada por qRT-PCR. Os valores de $\Delta \Delta$ Ct foram utilizados para determinar a expressão relativa tendo como controle endógeno o transcrito de $\beta$-actina. Os valores foram expressos como média $\pm \mathrm{DP}$, e a diferença significativa em relação ao grupo controle quando $\mathrm{p}<0,05\left(^{*}\right)$.

\subsubsection{Carga fúngica pulmonar dos animais submetidos ao protocolo de imunização} em associação com Pam3CSk4 e desafiados com $C$. gattii 
Para relacionar o efeito imunomodulador da administração do agonista de TLR2, Pam3CSk4, nas concentrações de $1 \mu \mathrm{g}$ ou $10 \mu \mathrm{g}$ na estratégia vacinal visando o controle da infecção por $C$. gattii, mensuramos a carga fúngica pulmonar dos animais após 14 dias de infecção. O homogeneizado do pulmão foi utilizado no ensaio de CFU, e animais que receberam $1 \mu \mathrm{g}$ ou $10 \mu \mathrm{g}$ (Figura 24) de Pam3CSk4, como adjuvante no protocolo de imunização, não tiveram uma redução significativa na carga fúngica. Portanto, o ambiente citocínico e o perfil de células $\mathrm{TCD}^{+}{ }^{+}$diferenciadas no tecido pulmonar imunomodulado por Pam3CSk4, para ambas as concentrações administradas, não relacionam diretamente com o controle da progressão da infecção por $C$. gattii.

A

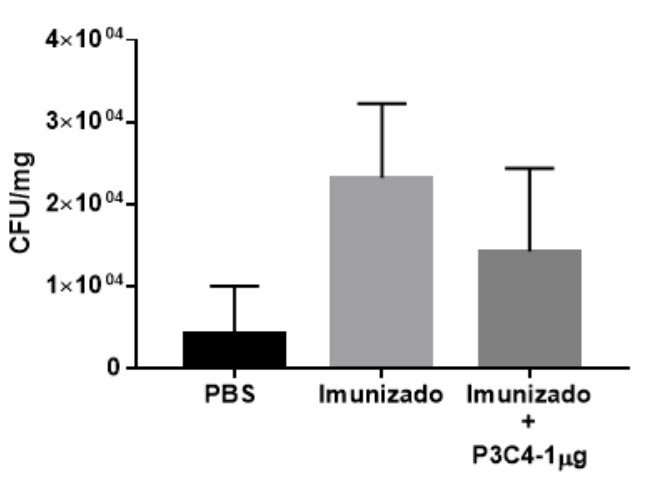

B

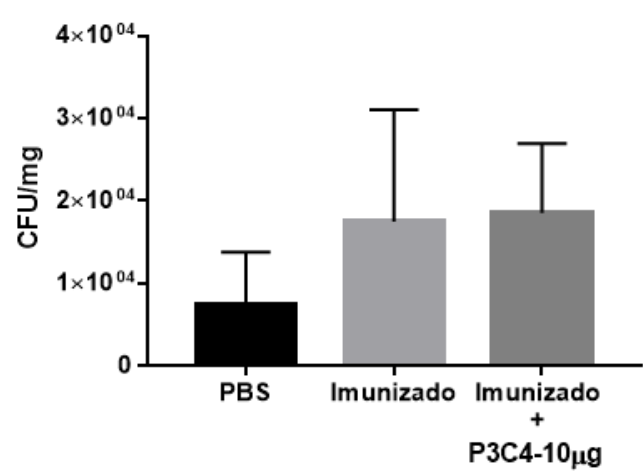

Figura 24. Carga fúngica pulmonar dos camundongos submetidos a etapa de imunização com o adjuvante Pam3CSk4 $1 \mu$ g ou $10 \mu$ g e desafiados com $C$. gattii. Os animais, após os procedimentos de imunização de forma associada ou não com (A) $1 \mu \mathrm{g}$ ou (B) $10 \mu \mathrm{g}$ de Pam3CSk4, foram infectados com $1 \times 10^{5}$ leveduras de C. gattii no $14^{\circ}$ dia pós-imunização. Após 14 dias de infecção, a carga fúngica foi quantificada a partir do homogeneizado do pulmão através de CFU (CFU/mg) realizado em ágar Sabouraud dextrose. Os valores foram expressos como média $\pm \mathrm{DP}$, com $\mathrm{p}<0,05\left(^{*}\right)$ para diferença significativa.

\subsubsection{Análise histopatológica do pulmão dos animais imunizados, em associação com Pam3CSk4, e infectados com $C$. gattii}

Visto que o efeito imunomodulador após a administração de $1 \mu \mathrm{g}$ ou $10 \mu \mathrm{g}$ de Pam3CSk4, associado às leveduras inativadas de $C$. gattii, não conteve a carga de $C$. gattii no tecido pulmonar, optamos pela avaliação de cortes histológicos do pulmão para observar a celularidade e a formação de granulomas. Após 14 dias de infecção com $C$. gattii, o pulmão foi obtido e procedido com técnicas de histologia para obter cortes do tecido corados em hematoxilina-eosina. Os animais do grupo PBS, não submetidos ao protocolo de imunização com leveduras inativadas de $C$. gattii, apresentaram leveduras distribuídas no parênquima e no interior dos alvéolos pulmonares, enquanto o infiltrado 
inflamatório e a formação de granulomas se apresentam de forma focal (Figura 25A-B e 26A-B). A mesma observação acerca da distribuição de leveduras vista no grupo PBS foi também constatada nos animais dos grupos Imunizados e no grupo Imunizado em associação com Pam3CSk4 nas concentrações de $1 \mu \mathrm{g}$ e $10 \mu \mathrm{g}$ (Figura 25C-F e 26C-F). O pulmão dos animais do grupo Imunizado apresentou granulomas mais delimitados acompanhado por uma celularidade mais intensa (Figura 25C-D e 26C-D). Já o pulmão dos camundongos do grupo Imunizado+P3C4 tiveram granulomas maiores e de forma difusa pelo tecido (Figura 25E-F e 26E-F). Entretanto, esses dados carecem de validação por análise morfométrica para quantificar o infiltrado inflamatório, a carga fúngica e o comprometimento do parênquima, análises que estão em andamento. Portanto, a administração de Pam3CSk4, para ambas as concentrações adotadas, favorece a formação de granulomas distribuídos de forma difusa pelo tecido pulmonar. 

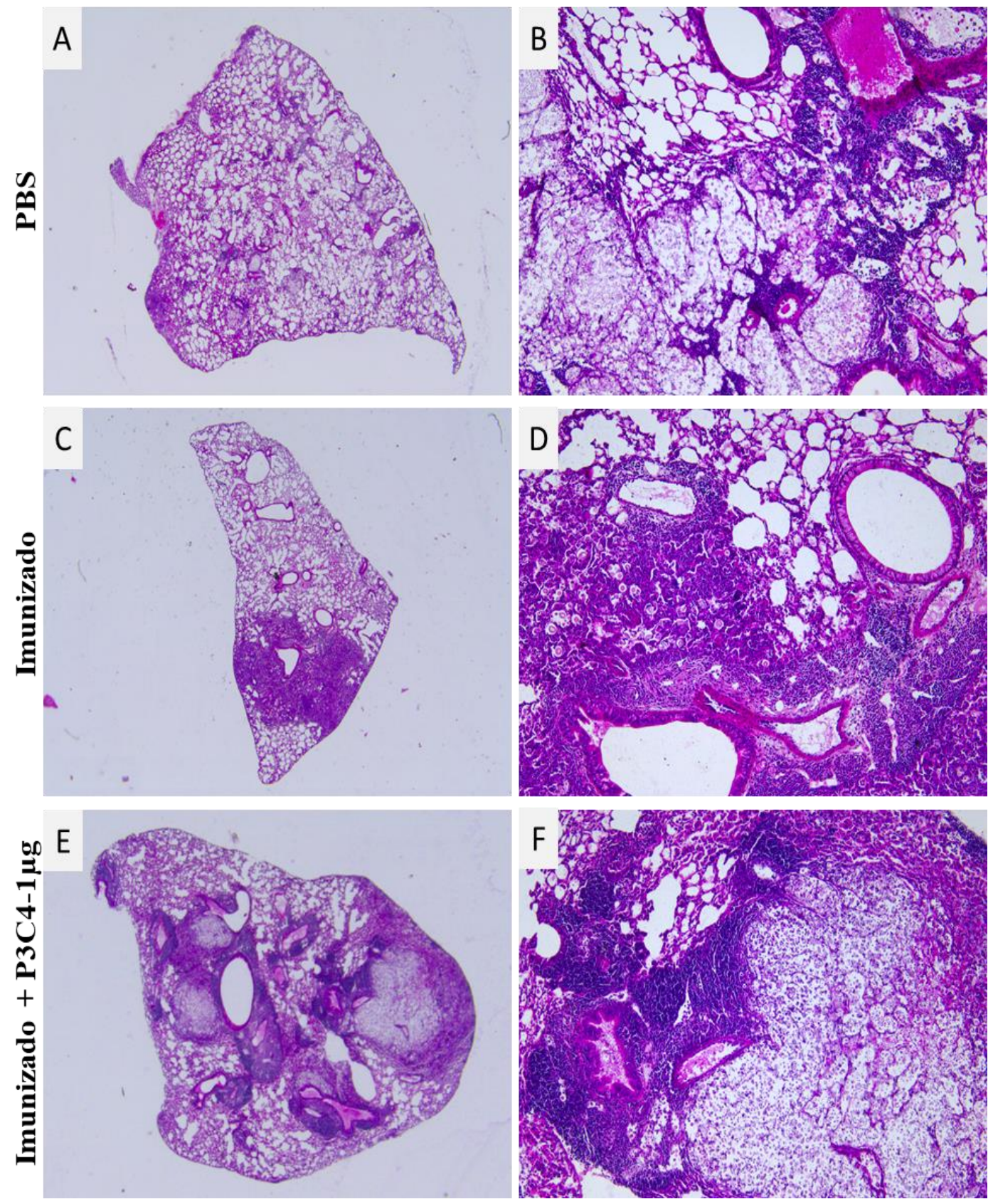

Figura 25. Histopatologia do pulmão dos camundongos submetidos a etapa de imunização, associado a administração de $1 \mu \mathrm{g}$ de Pam3CSk4, e desafiados com $C$. gattii. Os cortes histológicos representam o tecido pulmonar de camundongos submetidos ao protocolo de imunização com a administração em conjunto de $1 \mu \mathrm{g}$ de Pam3CSk4 (Imunizado+P3C4) ou veículo (Imunizado), e o grupo PBS representa animais não imunizados. Os cortes foram corados pela técnica de hematoxilina-eosina, e os cortes são representativos de cada grupo. As imagens A, C, E foram adquiridas em aumento de 1,25x e as imagens B, $\mathrm{D}, \mathrm{F}$ em aumento de 10x. 

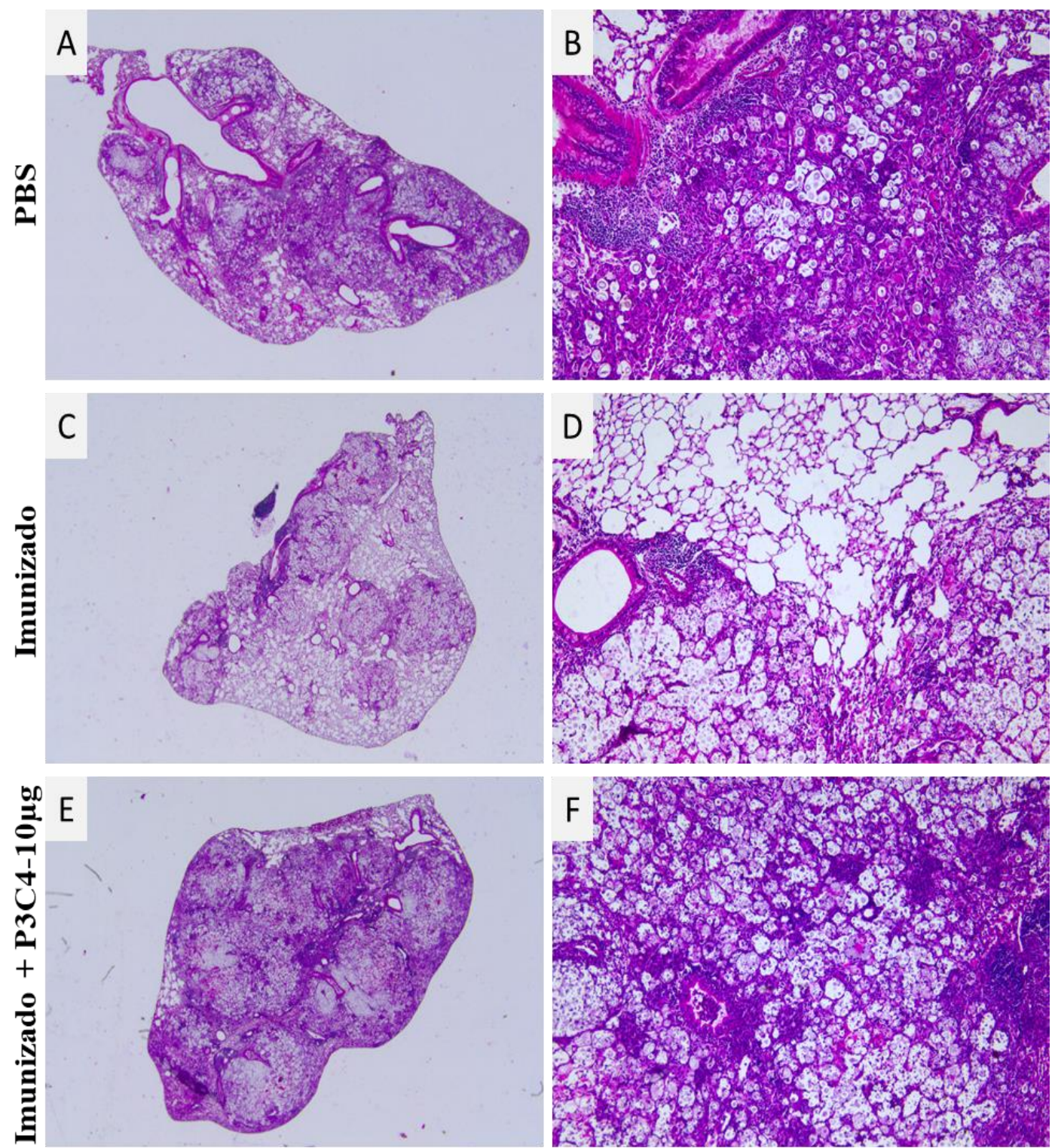

Figura 26. Histopatologia do pulmão dos camundongos submetidos a etapa de imunização, associado a administração de $10 \mu$ g de Pam3CSk4, e desafiados com $C$. gattii. Os cortes histológicos representam o tecido pulmonar de camundongos submetidos ao protocolo de imunização com a administração em conjunto de $10 \mu \mathrm{g}$ de Pam3CSk4 (Imunizado+P3C4) ou veículo (Imunizado), e o grupo PBS representa animais não imunizados. Os cortes foram corados pela técnica de hematoxilina-eosina, e os cortes são representativos de cada grupo. As imagens A, C, E foram adquiridas em aumento de 1,25x e as imagens B, $\mathrm{D}, \mathrm{F}$ em aumento de 10x. 
DISCUSSÃO 


\section{DISCUSSÃO}

As infecções fúngicas têm sido constatadas de forma mais frequente em pacientes imunocomprometidos, e as leveduras de Candida spp. e Cryptococcus spp são comumente encontradas em pacientes acometidos por infecções fúngicas invasivas. A criptococose tem uma incidência anual de 957.900 casos mundialmente, e as espécies Cryptococcus neoformans e Cryptococcus gattii são as principais causadoras (Park et al., 2009; Enoch et al., 2006). C. gattii é capaz de acometer indivíduos imunossuprimidos e imunocompetentes, podendo causar pneumonia e até mesmo ser disseminado pela corrente sanguínea, atingindo o sistema nervoso central e outros órgãos (Rajasingham et al., 2017). O fato de C. gattii acometer indivíduos saudáveis direcionou o presente estudo a avaliar uma estratégia vacinal associada a agonista de TLR2 nesse modelo de infecção, pois a escolha da infecção por $C$. neoformans para investigar uma abordagem de imunização contra a criptococose deve considerar um quadro de imunossupressão do hospedeiro. Outra justificativa pelo modelo de infecção com C. gattii se relaciona com o mecanismo desse patógeno de bloquear e/ou atenuar a diferenciação de células Th1 e Th17 (Elsegeiny et al., 2018), e isso ocasiona uma redução da produção de IFN- $\gamma$ e TNF$\alpha$ que altera a polarização de macrófagos com predomínio de subtipos celulares que não conferem proteção ao hospedeiro (Wright et al., 2002; Bashir et al., 2016). Portanto, direcionar a resposta imunitária do hospedeiro para perfis Th1, Th17 e M1 pode beneficiar o combate da infecção por $C$. gattii. Como candidatos, os agonistas de TLR2 são importantes moduladores da resposta imune através da atuação em células $\mathrm{B}, \mathrm{T}, \mathrm{T} \gamma \delta$ e macrófagos (Duthie et al., 2011; De Campos et al., in press). Logo, o objetivo do presente trabalho foi avaliar o efeito imunomodulador do agonista de TLR2, Pam3CSk4, como adjuvante em uma estratégia vacinal contra a infecção por $C$. gattii.

A ligação do agonista ao receptor TLR causa mudanças conformacionais com recrutamento de adaptadores intracelulares que desencadeia uma cascata de transdução de sinal que culmina na translocação de fatores para o núcleo visando a produção de mediadores pró-inflamatórios (Gilliet et al., 2008; Rosadini et al., 2015). Com isso, buscamos avaliar se a atividade imunomoduladora de Pam3CSk4 era capaz de induzir uma resposta imune pró-inflamatória em células da imunidade inata que teriam um dos contatos iniciais após a administração intranasal de Pam3CSk4 como adjuvante, considerando a nossa estratégia vacinal. Nessa linha, os macrófagos alveolares são a primeira linha de defesa contra diversos patógenos e correspondem a mais de $90 \%$ da população total de células no espaço alveolar (Nelson et al., 2020). Os macrófagos 
possuem uma plasticidade que altera de acordo com os estímulos e sinais encontrados no microambiente, dessa forma duas principais subpopulações de macrófagos se destacam: subtipo M1 oriundo da ativação pela via clássica, com perfil pró-inflamatório; subtipo M2 originado da ativação pela via alternativa, com característica anti-inflamatória (Mantovani et al., 2004; Shapouri-Moghaddam et al., 2018). Macrófagos M1 e as células de perfis Th1 e/ou Th17 têm sido requeridas na resposta protetora do hospedeiro contra infecções fúngicas invasivas (Kumaresan et al. 2018). Davis et al. demonstrou que macrófagos são altamente responsivos alterando o padrão de polarização in vitro e in vivo em resposta ao estímulo com citocinas, e essa capacidade de polarização/repolarização dos macrófagos contribui na redução da carga fúngica de C. neoformans (Davis et al., 2013). Baseado na importância dos macrófagos alveolares e de sua plasticidade na resposta imune inata frente a criptococose, consideramos a linhagem celular de macrófagos alveolares, AMJ2-C11, para avaliar a partir do estímulo com Pam3CSk4 a indução da resposta pró-inflamatória. O efeito imunomodulador de Pam3CSk4 em células AMJ2-C11 favoreceu um intenso aumento na expressão de TLR2 na superfície dessas células, também observamos o predomínio de uma resposta pró-inflamatória justificado pelos níveis elevados de TNF- $\alpha$ e alta expressão relativa de iNOS após estímulo com Pam3CSk4.

O perfil de resposta pró-inflamatório desencadeado por Pam3CSk4 em células AMJ2-C11 foi avaliado na presença de C. gattii, e o efeito imunomodulador de Pam3CSk4 foi capaz de induzir níveis elevados de TNF- $\alpha$ mesmo em macrófagos alveolares co-cultivados com $C$. gattii. Esse mesmo efeito de Pam3CSk4 também foi verificado por nosso grupo em células RAW 264.7, origem peritoneal, incubadas com $C$. gattii (De Campos et al., in press), demonstrando que a ativação de TLR2 compromete a regulação da produção de TNF- $\alpha$ pelas leveduras de $C$. gattii. Essa modulação induzida por Pam3CSk4 também aumentou a atividade fagocítica dos macrófagos alveolares frente ao $C$. gattii, entretanto o efeito fungistático de células AMJ2-C11 ativadas via TLR2 não atingiu nível desejado na infecção in vitro por $C$. gattii. Esse fato pode ser relacionado com a resposta pró-inflamatória polarizada de forma intensa para o perfil M1, pois estudos com o modelo de infecção com $C$. neoformans indicam que um balanço entre uma resposta pró- e anti-inflamatória é a forma efetiva no controle da criptococose. Esse fator está inserido na associação entre tolerância e resistência na relação patógenohospedeiro no caso da criptococose (Soares et al. 2017). 
A criptococose experimental tem sido estudada majoritariamente em modelo murino nos backgrounds BALB/c e C57BL/6. Essas linhagens murinas são consideradas na avaliação de estratégias vacinais e a administração via intranasal é uma rota de escolha para vários modelos de infecção devido ao favorecimento da montagem de resposta imunitária em compartimentos sistêmicos e regiões de mucosa, contribuindo na resposta imune celular e humoral mais efetiva (Thompson et al., 2011). Chaturvedi et al. propôs um protocolo de imunização contra $C$. gattii, avaliado em camundongos BALB/c, através de frações específicas de proteínas da parede celular e do citoplasma que levaram a redução da carga fúngica pulmonar e aumento da sobrevida dos animais, após a administração intranasal dos componentes para imunização. A imunização dos animais com frações da parede celular frente a infecção com $C$. neoformans também promoveu uma maior responsividade de esplenócitos na presença das mesmas frações da parede celular utilizadas na imunização, e observaram um predomínio na produção de citocinas de perfil Th1, embora a resolução da infecção não foi completa (Chaturvedi et al., 2014). Specht et al utilizou camundongos C57BL/6 para verificar o efeito de partículas de $\beta$ glucanos como componente da imunização contra a infecção por $C$. neoformans e $C$. gattii, e esse modelo murino possibilitou comprovar o efeito benéfico de partículas de $\beta$ glucano, administrada via intranasal, como forma vacinal contra a criptococose (Specht et al., 2015). Diante desse contexto, consideramos a administração intranasal como rota de escolha em nosso protocolo de imunização, e a opção por leveduras inativadas de $C$. gattii é justificada pelos achados de Muth et al. que demonstraram uma montagem da resposta imune celular de maneira mais robusta com a administração de formas intactas de C. neoformans comparado com antígenos solúveis do patógeno (Muth et al., 1995). A aplicação de leveduras inativadas de Cryptococcus spp. também é explorada em modelos de vacinação com formas mutadas de leveduras para determinados fatores de virulência que possam favorecer a montagem da resposta imune celular efetora (Yina Wang et al., 2019).

O presente trabalho iniciou a aplicação do protocolo A de imunização em camundongos BALB/c, e o efeito imunomodulador de Pam3CSk4 como adjuvante foi avaliado previamente no contexto da imunização para, em seguida, testarmos o protocolo A de imunização na infecção por $C$. gattii. Nesse protocolo buscamos extensamente averiguar o período pós-imunização adequado para o início da infecção com $C$. gattii visando o desafio dos animais imunizados. Os dias 14 e 21 pós-imunização foram avaliados, e para ambos os períodos o grupo de animais que receberam a imunização 
associada com a administração de Pam3CSk4 não apresentaram título maior de antiGXM e um perfil citocínico desejado para o combate da criptococose. No entanto, no período de 21 dias pós-imunização constatamos que as células esplênicas do grupo Imunizado+P3C4 estavam mais responsivas e, com isso, esse período foi adotado para proceder com o desafio com $C$. gattii no sentido de avaliar o protocolo A de imunização. Como descrito na seção Resultados, a imunização associada com Pam3CSk4 no protocolo A de imunização não favoreceu o controle da carga fúngica no tecido pulmonar após infecção com $C$. gattii. Isso levou a readequação do estudo para o protocolo B de imunização, que se baseou no protocolo de imunização utilizado por Yina Wang et al. (Yina Wang et al., 2019). Com isso, o número de leveduras inativadas administradas via intranasal foi aumentado e o intervalo entre os períodos de imunização foi estendido, perfazendo o protocolo B de imunização. Além disso, os camundongos C57BL/6 foram utilizados na avaliação do novo protocolo de imunização devido a maior expressão de TLR2 em macrófagos alveolares da linhagem C57BL/6 comparado aos animais BALB/c (Liu et al. 2005), isso favoreceria o efeito imunomodulador de Pam3CSk4 após infusão intranasal. Nesse sentido, o efeito de Pam3CSk4 em macrófagos alveolares da linhagem AMJ2-C11 (célula proveniente de camundongos C57BL/6) com a polarização para o perfil M1 ratifica a modulação desse agonista no macrófago alveolar de C57BL/6. Por fim, o protocolo B de imunização considerou duas quantidades de Pam3CSk4, $1 \mu$ g e 10 $\mu \mathrm{g}$, em grupos distintos para determinar se o efeito de Pam3CSk4 como adjuvante seria dose-dependente.

A resposta imune humoral acompanhada por níveis elevados de imunoglobulinas específicas para GXM é benéfica no controle da infecção por C. gattii (Dromer et al., 1987; Casadevall et al., 1998) e é um indicativo de um protocolo de imunização eficaz. Além disso, a isotipagem de imunoglobulinas séricas contribui na avaliação do perfil de resposta imune efetora propiciada pela imunização (Vidarsson et al., 2014). Na estratégia vacinal com o protocolo A de imunização, observamos no período restrito à etapa de imunização que a administração de Pam3CSk4, associada às leveduras inativadas de $C$. gattii, resultou em níveis séricos reduzidos dos isotipos IgG1, IgG2a, IgG2b e IgM no $21^{\circ}$ dia pós-imunização. Esses dados sugerem fortemente que o protocolo de imunização associado com Pam3CSk4 induz a montagem de uma resposta imunitária supostamente de baixa eficiência contra a criptococose. Em relação ao protocolo B de imunização, a isotipagem de imunoglobulinas foi determinada após o desafio dos camundongos com $C$.

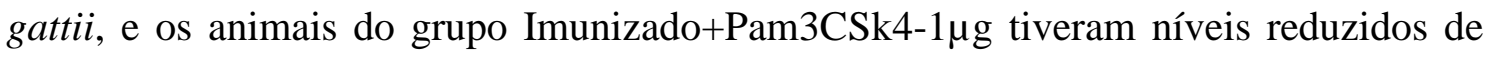


IgG1, IgG2a e IgA. Os níveis dessas imunoglobulinas indicam que a imunização associada com Pam3CSk4-1ug não favoreceu a produção de isotipos efetores contra a infecção por C. gattii, já que IgG1 é o isotipo de maior abundância após a vacinação e o isotipo IgG2a é de importância para o reconhecimento de carboidratos. No mesmo sentido da atuação do isotipo IgG2a, os níveis séricos de anticorpos contra o principal fator de virulência de C. gattii, GXM, foram avaliadas para as subclasses de IgG e IgM. Os animais do grupo Imunizado+P3C4 tiveram níveis séricos de IgG e IgM anti-GXM em patamares próximos ao encontrado nos grupos controles. Estudos demonstraram que a produção de anticorpos específicos contra GXM no curso da infecção de fato pode apresentar títulos reduzidos e, por isso, a administração de anticorpo monoclonal específico para GXM tem mostrado resultados promissores no controle da criptococose em modelos murino e inclusive em estudos clínicos (Casadevall et al., 1998; Shapiro et al., 2002; Larsen et al., 2005).

$\mathrm{Na}$ continuidade da avaliação do efeito imunomodulador de Pam3CSk4 como adjuvante nos protocolos de imunização, o perfil de citocinas no tecido pulmonar se tornou uma ferramenta valiosa. Essa avaliação após execução do protocolo A de imunização revelou níveis reduzidos de IL-12p40, TNF- $\alpha$, IL-17 e IL-10 nos animais que receberam Pam3CSk4 comparado ao grupo Imunizado referente ao $21^{\circ}$ dia pósimunização, indicando que o agonista de TLR2 regulou negativamente o ambiente próinflamatório no pulmão. Nesse $21^{\circ}$ dia pós-imunização, a capacidade responsiva das células esplênicas dos camundongos do grupo Imunizado+P3C4 foi testada frente a infecção in vitro com $C$. gattii e, através dos níveis de TNF- $\alpha$ produzidos pelas células esplênicas, foi perceptível que Pam3CSk4 não intensificou a responsividade a nível sistêmico. Esses dados evidenciaram que Pam3CSk4 como adjuvante suprime a produção de mediadores pró-inflamatórios no tecido pulmonar 21 dias pós-imunização, em camundongos BALB/c. Isso é corroborado pelo predomínio da citocina anti-inflamatória IL-4 no homogeneizado do baço obtido dos animais imunizados em associação com Pam3CSk4 referente ao $21^{\circ}$ dia pós-imunização, e também pelos níveis elevados de IL10 no tecido pulmonar, portanto, esses dados em conjunto reforçam a hipótese de Pam3CSk4 suprimir o perfil pró-inflamatório no pulmão. Consequentemente, esse efeito imunomodulador de Pam3CSk4 associado com leveduras de C. gattii não favoreceu o controle da carga fúngica pulmonar e o aumento da sobrevida após a infecção com $C$. gattii após a aplicação do protocolo A de imunização. Sabemos que as leveduras de $C$. gattii são importantes supressoras da resposta imunitária do hospedeiro através da cápsula 
polissacarídica e outros fatores de virulência, como demonstrado em monócitos (Vecchiarelli et al., 1995). Portanto, o protocolo A de imunização em camundongos BALB/c evidenciou um efeito supressor de Pam3CSk4 como adjuvante na estratégia vacinal contra $C$. gattii, e o predomínio de uma resposta anti-inflamatória é ineficaz no controle da criptococose (Mencacci et al., 2001; Arora et al., 2005; Jain et al., 2009; Pikman e Ben-Ami, 2012).

Como ressaltado anteriormente, o protocolo B de imunização teve uma adequação no tempo de imunização e o modelo murino C57BL/6 foi escolhido devido a expressão aumentada de TLR2 em macrófagos alveolares, fatores facilitadores para o efeito imunomodulador de Pam3CSk4 com direcionamento de uma resposta pró-inflamatória predominante. $\mathrm{O}$ protocolo $\mathrm{B}$ de imunização não avaliou o período restrito a pósimunização que fosse mais adequado para o desafio com $C$. gattii, já que esse fator estava previsto no protocolo de imunização estipulado por Yina Wang et al. (Yina Wang et al., 2019). A partir do protocolo B de imunização, observamos no tecido pulmonar de animais infectados com $C$. gattii após a imunização associada com Pam3CSk4-1 $\mu$ g que os níveis de IL-17 e IL-1 $\beta$ se encontravam elevados, no entanto a expressão relativa do fator de transcrição ROR- $\gamma$ t não alterou significativamente entre os grupos. Isso demonstra que Pam3CSk4 induziu a produção de IL-17 no tecido pulmonar com ausência do predomínio de células Th17 diferenciadas. Estudos prévios verificaram níveis elevados de IL-17 no pulmão induzido por C. neoformans com ausência de células Th17 (Wozniak et al., 2011), e níveis aumentados de IL-17 e IL-1 $\beta$ também foram detectados em PBMC incubados com C. gattii (Schoffelen et al., 2013). Além disso, Yina Wang et al. a partir da estratégia de vacinação com leveduras inativadas de $C$. gattii, as quais contém uma mutação para E3 ligase, constatou a indução de células T CD4+ produtoras de IL-17 que não apresentaram papel essencial na proteção contra a infecção por $C$. gattii (Yina Wang et $a l ., 2019)$. Ainda nessa linha investigativa, os animais do grupo Imunizado+Pam3CSk4lug apresentou uma redução na expressão relativa de T-bet e um aumento na expressão relativa de Foxp3. Esses dados sugerem que a imunização associada com Pam3CSk4-1ug promove uma prevalência de células $\mathrm{T}$ regulatórias no tecido pulmonar acompanhado pela menor frequência de células Th1, sendo que esse balanço de células T $\mathrm{CD}^{+}$ diferenciadas não contribuem fortemente para o combate da infecção por $C$. gattii. Esse fato é justificado através de outras estratégias de vacinação que obtiveram sucesso no controle da criptococose através da indução de células Th1 acompanhado por altos níveis de IFN- $\gamma$ (Yina Wang et al., 2019; Wozniak et al. 2011). Há uma possibilidade de que as 
células $\mathrm{T}$ regulatórias foram induzidas no pulmão dos animais que receberam $1 \mu \mathrm{g}$ de Pam3CSk4 devido a uma resposta imune pró-inflamatória exacerbada no estágio inicial da infecção e, dessa forma, levou a uma regulação da resposta imune que suprimiu células de perfil Th1. Portanto, o efeito imunomodulador de $1 \mu \mathrm{g}$ de Pam3CSk4 associado à imunização não direcionou a diferenciação de células T $\mathrm{CD} 4^{+}$efetoras no pulmão para o controle da infecção por $C$. gattii.

Como visto anteriormente, os animais imunizados em associação com $1 \mu \mathrm{g}$ de Pam3CSk4 ocasionou, após a infecção com C. gattii, um ambiente caracterizado por fatores relacionados com células $\mathrm{T}$ regulatórias. Essas células suprimem células próinflamatórias através da inibição da produção de citocinas, modulação de células apresentadoras de antígenos (APCs) ou por moléculas reguladoras que expressam em sua superfície celular (Vignali et al., 2008). Um dado interessante é a capacidade de células T regulatórias em suprimir a resposta Th2, através da supressão de IRF-4 no pulmão, contendo o crescimento de $C$. neoformans (Shulze et al., 2014; Wiesner et al., 2016). Entretanto, um estudo mais aprofundado sobre o papel das células $\mathrm{T}$ regulatórias no contexto da progressão da infecção por $C$. gattii ainda está em aberto. Em adição a isso, a avaliação dos animais imunizados em associação com $10 \mu \mathrm{g}$ de Pam3CSk4 demonstrou a ausência de uma expressão relativa de Foxp3 aumentada, assim como para T-bet e ROR$\gamma$ t. A administração de $10 \mu \mathrm{g}$ de Pam3CSk4, associada à imunização, ainda manteve elevado os níveis de IL-17 no pulmão após a infecção com $C$. gattii, no entanto, o perfil citocínico no pulmão foi caracterizado pela redução dos níveis de IFN- $\gamma$, IL-12p70, IL-6 e IL-10. Esses achados sugerem um efeito supressor em diferentes perfis de citocinas no pulmão através de altas concentrações de Pam3CSk4 associado com leveduras inativadas de C. gattii. Por fim, os níveis séricos elevados de IL-4 nos animais do grupo imunizado em associação com $10 \mu \mathrm{g}$ de Pam3CSk4, e infectados com C. gattii, reforçam o caráter supressor do agonista de TLR2 na indução de citocinas e um perfil celular do eixo Th1.

Dentre as diferentes abordagens realizadas no protocolo B de imunização, foi evidente a permanência de níveis aumentados de IL-17 no tecido pulmonar nos camundongos infectados após a etapa de imunização associada com $1 \mu \mathrm{g}$ ou $10 \mu \mathrm{g}$ de Pam3CSk4. Esse achado não se relaciona com a presença de células Th17 e isso demonstra que outras células mantém a produção de IL-17, fato que ocasiona um recrutamento celular elevado para o sítio de infecção com a possibilidade de dano ao tecido pulmonar. Na análise histopatológica verificamos que os animais imunizados em associação com Pam3CSk4 apresentam uma distribuição mais difusa de granulomas com 
focos contendo alta celularidade. Destaca-se no grupo imunizado em associação com 10 $\mu \mathrm{g}$ de Pam3CSk4 um comprometimento elevado do parênquima pulmonar devido ao espaço ocupado por vários granulomas, esse fato pode correlacionar com a baixa detecção de citocinas de diferentes perfis visto nesse grupo. Portanto, o efeito imunomodulador de Pam3CSk4, associado com a imunização, está vinculado com um perfil de resposta imune com característica supressora/regulatória induzido após a infecção com C. gattii, fato que impede o controle da criptococose. 
CONCLUSÃO 


\section{CONCLUSÃO}

O presente trabalho demonstra que a estratégia vacinal contra $C$. gattii a partir do efeito imunomodulador de Pam3CSk4 associado com leveduras inativadas de C. gattii induziu uma resposta pró-inflamatória insuficiente para controlar a infecção por $C$. gattii. Isso se relaciona com um microambiente no tecido pulmonar com um perfil de resposta imune com característica supressora/regulatória induzido após a infecção com C. gattii, fato observado na criptococose experimental nos modelos murinos BALB/c e C57B1/6. 


\section{REFERÊNCIAS BIBLIOGRÁFICAS}




\section{REFERÊNCIAS BIBLIOGRÁFICAS}

ADEREM, A.; ULEVITCH, R. J. Toll-like receptors in the induction of the innate immune response. Nature. v. 406, p. 782-7, 2000.

AKIRA, S.; UEMATSU, S.; TAKEUCHI, O. Pathogen recognition and innate immunity. Cell. v. 124, n. 4, p. 783-801, Feb 242006.

ALIPRANTIS, A. O. et al. Cell activation and apoptosis by bacterial lipoproteins through toll-like receptor-2. Science, v. 285, p. 736-9, 1999.

ANGKASEKWINAI, P. et al. Cryptococcus gattii infection dampens Th1 and Th17 responses by attenuating dendritic cell function and pulmonary chemokine expression in the immunocompetent hosts. Infect Immun, v. 82, p. 3880-90, 2014.

ANTACHOPOULOS, C.; WALSH, T. J. Immunotherapy of Cryptococcus infections. Clin Microbiol Infect. v. 18, n. 2, p. 126-133, 2012.

ANTONELLA, M. et al. Defective antifungal T-helper 1 (TH1) immunity in a murine model of allogeneic T-cell-depleted bone marrow transplantation and its restoration by treatment with TH2 cytokine antagonists. Blood, v. 97, n. 5, p. 1483-1490, 2001.

ARORA, S. et al. Role of IFN-gamma in regulating T2 immunity and the development of alternatively activated macrophages during allergic bronchopulmonary mycosis. $\mathbf{J}$ Immunol, v. 174, n. 10, p. 6346-56, May 152005.

ASCIOGLU, S. et al. Defining Opportunistic Invasive Fungal Infections in Immunocompromised Patients with Cancer and Hematopoietic Stem Cell Transplants: An International Consensus. Clinical Infectious Diseases, v. 34, p. 7-14, 2002.

BASHIR, S. et al. Macrophage polarization: the link between inflammation and related diseases. Inflamm Res, v. 65, n. 1, p. 1-11, Jan 2016.

BASTO, A. P.; LEITAO, A. Targeting TLR2 for vaccine development. J Immunol Res, v. 2014, p. 619410, 2014.

BEN-ABDALLAH, M. et al. Fungal-Induced Cell Cycle Impairment, Chromosome Instability and Apoptosis via Differential Activation of NF-кB. PLOS Pathogens, v. 8, p. e1002555, 2012.

BENEDICT, K. et al. Estimation of Direct Healthcare Costs of Fungal Diseases in the United States. Clin. Infect. Dis. v. 68, n. 11, p. 1791-1797, 2019.

BERNARD, J. J. et al. Ultraviolet radiation damages self-noncoding RNA and is detected by TLR3. Nat Med. v. 18, p. 1286-90, 2012.

BIONDO, C. et al. MyD88 and TLR2, but not TLR4, are required for host defense against Cryptococcus neoformans. Eur J. Immunol. v. 35, p. 870-878, 2005.

BLASIUS, A. L.; BEUTLER, B. Intracellular toll-like receptors. Immunity. v. 32, p. 305-15, 2010. 
BOEKHOUT, T. et al. Hybrid genotypes in the pathogenic yeast Cryptococcus neoformans. Microbiology, v. 147, p. 891-907, 2001.

BONICHE, C. et al. Immunotherapy against Systemic Fungal Infections Based on Monoclonal Antibodies. J. Fungi. v. 6, p. 31, 2020.

BORGHI, M. et al. Antifungal Th immunity: growing up in family. Front. Immunol. v. 5, p. 506, 2014.

BOTOS, I; SEGAL, D. M.; DAVIES, D. R. The structural biology of Toll-like receptors. Structure. v. 19, n. 4, p. 447-59, Apr 132011.

BRANDT, K. J. et al. TLR2 Ligands Induce NF- $\kappa \mathrm{B}$ activation from endosomal compartments of human monocytes. PLoS One. v. 8, n. 12, p. e80743, 2013.

BRZEZIŃSKA-BŁASZCZYK, E.; WIERZBICKI, M. Mast cell Toll-like receptors (TLRs). Postepy Hig Med Dosw (Online). v. 64, p. 11-21, Jan 202010.

CAMPUZANO, A.; WORMLEY, F. L. Innate Immunity against Cryptococcus, from Recognition to Elimination. J Fungi (Basel), v. 4, n. 1, p. 33, Mar 7, 2018.

CAPILLA, J. et al. Saccharomyces cerevisiae as a vaccine against coccidioidomycosis, Vaccine. v. 27, n. 27, p. 3662-3668, 2009.

CASADEVALL, A. et al. Characterization of a murine monoclonal antibody to Cryptococcus neoformans polysaccharide that is a candidate for human therapeutic studies. Antimicrob Agents Chemother, v. 42, n. 6, p. 1437-1446, 1998.

CASADEVALL, A.; PERFECT, J. R. Cryptococcus neoformans. Med Mycol, v. 37, n. 5, p. 371-371, 1998.

CASSONE, A. Fungal vaccines: real progress from real challenges. Lancet Infect. Dis. v. 8, p. 114-124, 2008.

CASSONE, A. Vulvovaginal Candida albicansinfection: pathogenesis, immunity and vaccine prospects. BJOG. v. 122, p. 785-794, 2014.

CHAI, L. Y. et al. Modulation of Toll-like receptor 2 (TLR2) and TLR4 responses by Aspergillus fumigatus. Infect Immun. v. 77, p. 2184-92, 2009.

CHATURVEDI, A. K. et al. Vaccine-mediated immune responses to experimental pulmonary Cryptococcus gattii infection in mice. PLoS One, v. 9, n. 8, p. e104316. Aug 132014.

CHAYAKULKEEREE, M.; PERFECT, J. R. Cryptococcosis. Infectious Disease Clinics of North America, v. 20, p. 507-544, 2006.

CHEN, S. C. A.; MEYER, W.; SORRELL, T. C. Cryptococcus gattii Infections. Clinical Microbiology Reviews, v. 27, n. 4, p. 980-1024, Oct 2014.

CHERNIAK, R. et al. Variação na estrutura de glucuronoxylomannan em isolados de pacientes com meningite criptocócica recorrente. Infect Immun., v. 63, n. 5, p. 1899905, 1995. 
CHRISMAN, C. J. et al. Phospholipids Trigger Cryptococcus neoformans Capsular Enlargement during Interactions with Amoebae and Macrophages. PLOS Pathogens, v. 7, p. e1002047, 2011.

CHUA, B. Y. et al. A self-adjuvanting lipopeptide-based vaccine candidate for the treatment of hepatitis C virus infection. Vaccine, v. 26, p. 4866-75, 2008.

CLARK, C.; DRUMMOND, R. A. The Hidden Cost of Modern Medical Interventions: How Medical Advances Have Shaped the Prevalence of Human Fungal Disease. Pathogens. v. 8, n. 2, p. 45, Apr 42019.

CLEMONS, K. V.; BRUMMER, E.; STEVENS, D. A. Cytokine treatment of central nervous system infection: efficacy of interleukin-12 alone and synergy with conventional antifungal therapy in experimental cryptococcosis. Antimicrob Agents Chemother. v. 38, n. 3, p. 460-464, 1994.

CLEMONS, K. V.; LUTZ, J. E.; STEVENS, D. A. Efficacy of recombinant gamma interferon for treatment of systemic cryptococcosis in SCID mice. Antimicrob Agents Chemother. v. 45, n. 3, p. 686-689, 2001.

COELHO, C.; BOCCA, A. L.; CASADEVAlL, A, Chapter One - The Tools for Virulence of Cryptococcus neoformans. Advances in Applied Microbiology, v. 87, p. $1-41,2014$.

COELHO, C.; BOCCA, A. L.; CASADEVALL, A. The intracellular life of Cryptococcus neoformans. Annu. Rev. Pathol., v. 9, p. 219-238, 2014.

COLOM, M. F. et al. First case of human cryptococcosis due to Cryptococcus neoformans var. gattii in Spain. J. Clin. Microbiol., v. 43, p. 3548-3550, 2005.

Consenso em criptococose: 2008. Revista da Sociedade Brasileira de Medicina Tropical, v. 41, n. 5, p. 524-544, 2008.

CORREA, M. P. S. C. et al. Criptococose em crianças no estado do Pará, Brasil. Revista da Sociedade Brasileira de Medicina Tropical, v. 32, p. 505-508, 1999.

COTE-SIERRA, J. et al. Bacterial lipoprotein-based vaccines induce tumor necrosis factor-dependent type 1 protective immunity against Leishmania major. Infect Immun, v. 70, p. 240-8, 2002.

CROSS, C. E.; BANCROFT, G. J. Ingestion of acapsular Cryptococcus neoformans occurs via mannose and $\beta$-glucan receptors, resulting in cytokine production and increased phagocytosis of the encapsulated form. Infect. Immun. v. 63, p. 2604-2611, 1995.

DATTA, K.; HAMAD, M. Immunotherapy of Fungal Infections. Immunol Invest. v. 44, n. 8, p. 738-776, 2015.

DAVIS, M. J. et al. Macrophage M1/M2 polarization dynamically adapts to changes in cytokine microenvironments in Cryptococcus neoformans infection. mBio, v. 4, n. 3, p. e00264-e002713, Jun 18, 2013. 
DE CAMPOS, G. Y. et al. Pro-inflammatory response ensured by LPS and Pam3CSK4 in RAW 264.7 cells did not improve a fungistatic effect on Cryptococcus gattii infection. PeerJ, Oct 20. Ahead of print.

DROMER, F. et al. Production, characterization, and antibody specificity of a mouse monoclonal antibody reactive with Cryptococcus neoformans capsular polysaccharide. Infect Immun, v. 55, n. 3, p. 742-748, 1987.

DUTHIE, M. S. et al. Use of defined TLR ligands as adjuvants within human vaccines. Immunol Rev, v. 239, p. 178-96, 2011.

EDWARDS, J. E. Fungal cell wall vaccines: an update. J. Med. Microbiol. v. 61, p. 895903, 2012.

ELENI, G. et al. Epidemiology of Cryptococcus gattii, British Columbia, Canada, 19992007. Emerging Infectious Disease Journal, v. 16, p. 251, 2010.

ELLIS, D. H. Cryptococcus neoformans var. gattii in Australia. J. Clin. Microbiol., v. 25, p. 430-431, 1987.

ELSEGEINY, W.; MARR, K. A.; WILLIAMSON, P. R. Immunology of Cryptococcal Infections: Developing a Rational Approach to Patient Therapy. Front Immunol, v. 9, p. 651, Apr 042018.

ENGELTHALER, D. M. et al. Cryptococcus gattii in North American Pacific Northwest: whole-population genome analysis provides insights into species evolution and dispersal. MBio., v. 5, n. 4, 2014.

ENOCH, D. A.; LUDLAM, H. A.; BROWN, N. M. Invasive fungal infections: a review of epidemiology and management options. J. Med. Microbiol, v. 55, p. 809, 2006.

EVA, P. et al. Cryptococcus neoformans capsular polysaccharide component galactoxylomannan induces apoptosis of human T-cells through activation of caspase- 8 . Cellular Microbiology, v. 8, p. 267-275, 2006.

FARHAT, K. et al. Heterodimerization of TLR2 with TLR1 or TLR6 expands the ligand spectrum but does not lead to differential signaling. J Leukoc Biol. v. 83, n. 3, p. 692701, Mar 2008.

FARIA, R. O. et al. Ocorrência de Cryptococcus neoformans em excretas de pombos na Cidade de Pelotas, Estado do Rio Grande do Sul. Revista da Sociedade Brasileira de Medicina Tropical, v. 43. n. 2. p. 198-200, 2010.

FARRER, R. A. et al. Genome evolution and innovation across the four major lineages of Cryptococcus gattii. MBio., v. 6, n. 5, 2015.

FISHER, F.; COOK, N. B. Micologia: fundamentos e diagnóstico. Rio de Janeiro: Revinter, 2001. p. 337.

FLO, T. H. et al. Differential expression of Toll-like receptor 2 in human cells. J Leukoc Biol. v. 69, n. 3, p. 474-81, Mar 2001. 
FRANZOT, S. P.; SALKIN, I. F.; CASADEVALL, A. Cryptococcus neoformans var. grubii: separate varietal status for Cryptococcus neoformans serotype A isolates. Journal of Clinical Microbiology, v. 37, p. 838-840, 1999.

FROMTLING, R. A.; SHADOMY, H. J.; JACOBSON, E. S. Decreased virulence in stable, acapsular mutants of Cryptococcus neoformans. Mycopatholoy. v. 79, p. 23-29, 1982.

FYFE, M. et al. Cryptococcus gattii infections on Vancouver Island, British Columbia, Canada: emergence of a tropical fungus in a temperate environment. Can Commun Dis Rep, v. 34, p. 1-12, 2008.

GERSTEIN, A. C. et al. Polyploid titan cells produce haploid and aneuploid progeny to promote stress adaptation. mBio, v. 6, n. 5, p. e01340-15, 2015.

GHANNOUM, M. A. Potential Role of Phospholipases in Virulence and Fungal Pathogenesis. Clinical Microbiology Reviews, v. 13, p. 122-143, 2000.

GIBSON, J. F.; JOHNSTON, S. A. Immunity to Cryptococcus neoformans and C. gattii during cryptococcosis. Fungal Genet Biol, v. 78, p. 76-86, 2015.

GILES, S. S. et al. Elucidating the pathogenesis of spores from the human fungal pathogen Cryptococcus neoformans. Infect. Immun. v. 77, p. 3491-3500, 2009.

GILLIET, M.; CAO, W.; LIU, Y. J. Plasmacytoid dendritic cells: sensing nucleic acids in viral infection and autoimmune diseases. Nat Rev Immunol, v. 8, n. 8, p. 594-606, Aug 2008.

GROLL, A. H. et al. Invasive aspergillosis in children and adolescents. Curr Pharm Des, v. 19, p. 3545-68, 2013.

HAJISHENGALLIS, G. et al. Novel mechanisms and functions of complement. Nat. Immunol. v. 18, n. 12, p. 1288, 2017.

HAJJEH, R. A. et al. Cryptococcosis: population-based multistate active surveillance and risk factors in human immunodeficiency virus-infected persons. Cryptococcal Active Surveillance Group. J Infect Dis., v. 179, n. 2, p. 449-454, 1999.

HAMAD, M. Antifungal immunotherapy and immunomodulation: a double-hitter approach to deal with invasive fungal infections. Scand J Immunol. v. 67, n. 6, p. 533$543,2008$.

HARDISON, S. E. et al. Protective immunity against pulmonary cryptococcosis is associated with STAT1-mediated classical macrophage activation. J Immunol. v. 189, n. 8, p. 4060-4068, 2012.

HAWKSWORTH, D. L. The magnitude of fungal diversity: the 1.5 million species estimate revisited. Mycol. Res., v. 105, p. 1422-1432, 2001.

HEIL, F. et al. Species-specific recognition of single-stranded RNA via toll-like receptor 7 and 8. Science. v. 303, n. 5663, p. 1526-9, Mar 52004. 
HIRSCHFELD, M. et al. Signaling by toll-like receptor 2 and 4 agonists results in differential gene expression in murine macrophages. Infect Immun, v. 69, p. 1477-82, 2001.

HUSTON, S. M. et al. Cryptococcus gattii is killed by dendritic cells, but evades adaptive immunity by failing to induce dendritic cell maturation. J Immunol, v. 191, p. 249-61, 2013.

IANNITTI, R. G.; CARVALHO, A.; ROMANI, L. From memory to antifungal vaccine design. Trends Immunol. v. 33, n. 9, p. 467-474, 2012.

IBRAHIM, A. S. et al. NDV-3 protects mice from vulvovaginal candidiasis through Tand B-cell immune response. Vaccine. v. 31, p. 47, 2013.

IKEDA-DANTSUJI, Y. et al. Interferon- $\gamma$ promotes phagocytosis of Cryptococcus neoformans but not Cryptococcus gattii by murine macrophages. Journal of Infection and Chemotherapy, v. 21, n. 12, p. 831-836, 2015. ISSN 1341-321X.

IN HEITMAN, J. et al. Cryptococcus: from pathogen to model yeast. ASM Press, 2010

IVEY, F. D. et al. Identification of protective antigen of Coccidioides immitis by expression library immunization. Vaccine. v. 21, p. 4359-67, 2003.

JAIN, A. V. et al. Th2 but not Th1 immune bias results in altered lung functions in a murine model of pulmonary Cryptococcus neoformans infection. Infect Immun, v. 77, n. 12, p. 5389-99, Dec 2009.

JANEWAY, C. A. JR; MEDZHITOV, R. Innate immune recognition. Annu Rev Immunol, v. 20, p. 197-216, 2002.

JARVIS, J. N. et al. Adjunctive interferon-gamma immunotherapy for the treatment of HIV-associated cryptococcal meningitis: a randomized controlled trial. AIDS. v. 26, n. 9, p. 1105-1113, 2012.

JIN, M. S. et al. Crystal structure of the TLR1-TLR2 heterodimer induced by binding of a tri-acylated lipopeptide. Cell. v. 130, n. 6, p. 1071-82, Sep 212007.

JOUAULT, T. et al. Candida albicans phospholipomannan is sensed through toll-like receptors. J Infect Dis. v. 188, p. 165-72, 2003.

KANG, J. Y. et al. Recognition of lipopeptide patterns by Toll-like receptor 2-Toll-like receptor 6 heterodimer. Immunity. v. 31, n. 6, p. 873-84, Dec 182009.

KAWAI, T.; AKIRA, S. The role of pattern-recognition receptors in innate immunity: update on Toll-like receptors. Nat Immunol, v. 11, p. 373-84, 2010.

KAWAKAMI, K. et al. IL-12 protects mice against pulmonary and disseminated infection caused by Cryptococcus neoformans. Clin Exp Immunol. v. 104, n. 2, p. 208214, 1996.

KAWASAKI, T.; KAWAI, T. Toll-like receptor signaling pathways. Front Immunol. v. 5, p. 461. Sep 252014. 
KHAN, S. et al. Distinct uptake mechanisms but similar intracellular processing of two different toll-like receptor ligand-peptide conjugates in dendritic cells. J Biol Chem, v. 282, p. 21145-59, 2007.

KIDD, S. E. et al. A rare genotype of Cryptococcus gattii caused the cryptococcosis outbreak on Vancouver Island (British Columbia, Canada). Proceedings of the National Academy of Sciences of the United States of America, v. 101, p. 17258-17263, 2004.

KLEIN, K. R. et al. Identification of Cryptococcus gattii by use of L-canavanine glycine bromothymol blue medium and DNA sequencing. J Clin Microbiol, v. 47, n. 11, p. 36693672, 2009.

KLEINSCHEK, M. A. et al. Administration of IL-23 engages innate and adaptive immune mechanisms during fungal infection. Int Immunol. v. 22, n. 2, p. 81-90, 2010.

KOBLANSKY, A. A. et al. Recognition of profilin by toll-like receptor 12 is critical for host resistance to Toxoplasma gondii. Immunity. v. 38, p. 119-30, 2013.

KOMEGAE, E. N. et al. TLR2, TLR4 and the MyD88 signaling are crucial for the in vivo generation and the longevity of long-lived antibody-secreting cells. PLoS One, v. 8, p. e71185, 2013.

KUMAR, H.; KAWAI, T.; AKIRA, S. Pathogen recognition in the innate immune response. Biochem J, v. 420, p. 1-16, 2009.

KUMARESAN, P. R.; DA SILVA, T. A.; KONTOYIANNIS, D. P. Methods of Controlling Invasive Fungal Infections Using $\mathrm{CD}^{+} \mathrm{T}$ Cells. Front Immunol, v. 8, p. 1939, Jan 82018.

KWON-CHUNG, K. J.; RHODES, J. C. Encapsulation and melanin formation as indicators of virulence in Cryptococccus neoformans. Infection and Immunity, v. 51, p. 218-223, 1986.

LARSEN, R. A. et al. Phase I evaluation of the safety and pharmacokinetics of murinederived anticryptococcal antibody $18 \mathrm{~B} 7$ in subjects with treated cryptococcal meningitis. Antimicrob Agents Chemother, v. 49, n. 3, p. 952-958, 2005.

LEE, C. H. et al. TLR2-dependent modulation of dendritic cells by LT-IIa-B5, a novel mucosal adjuvant derived from a type II heat-labile enterotoxin. J Leukoc Biol, v. 90, p. 911-21, 2011.

LEE, S. M. et al. Toll-like receptor 10 is involved in induction of innate immune responses to influenza virus infection. Proc Natl Acad Sci U S A. v. 111, n. 10, p. 3793 8, Mar 112014.

LIU, C. F. et al. Mite allergen induces nitric oxide production in alveolar macrophage cell lines via CD14/toll-like receptor 4, and is inhibited by surfactant protein D. Clin Exp Allergy, v. 35, n. 12, p. 1615-24, Dec 2005.

LIU, M. et al. Immune responses induced by heat killed Saccharomyces cerevisiae: a vaccine against fungal infection, Vaccine. v. 29, n. 9, p. 1745-1753, 2011. 
LIU, M. et al. Saccharomyces as a vaccine against systemic candidiasis, Immunol. Invest. v. 41, n. 8, p. 847-855, 2012.

LORTHOLARY, O. Management of Cryptococcal Meningitis in AIDS: The Need for Specific Studies in Developing Countries. Clin. Infect. Dis. v. 45, p. 81-83, 2007.

MA, H. et al. The fatal fungal outbreak on Vancouver Island is characterized by enhanced intracellular parasitism driven by mitochondrial regulation. Proc Natl Acad Sci U S A, v. 106, p. 12980-5, 2009.

MA, H.; MAY, R. C. Virulence in Cryptococcus species. Adv Appl Microbiol, v. 67, p. 131-90, 2009.

MACDOUGALL, L.; FYFE, M. Emergence of Cryptococcus gattii in a Novel Environment Provides Clues to Its Incubation Period. Journal of Clinical Microbiology, v. 44, p. 1851-1852, 2006.

MANTOVANI, A. et al. The chemokine system in diverse forms of macrophage activation and polarization. Trends Immunol, v. 25, n. 12, p. 677-86, Dec 2004.

MATHUR, R. et al. A mouse model of Salmonella typhi infection. Cell. v. 151, p. 590602, 2012.

MCKIMMIE, C. S. et al. A TLR2 ligand suppresses inflammation by modulation of chemokine receptors and redirection of leukocyte migration. Blood, v. 113, p. 4224-31, 2009.

MCMULlAN, B. J.; SORRELL, T. C.; CHEN, S. C. Cryptococcus gattii infections: contemporary aspects of epidemiology, clinical manifestations and management of infection. Future Microbiol, v. 8, n. 12, p. 1613-31, Dec 2013.

MEYER, W. et al. Consensus multi-locus sequence typing scheme for Cryptococcus neoformans and Cryptococcus gattii. Med Mycol., v. 47, p. 561-570, 2009.

MEYER, W. et al. Hybridization probes for conventional DNA fingerprinting used as single primers in the polymerase chain reaction to distinguish strains of Cryptococcus neoformans. J. Clin. Microbiol., v. 31, p. 2274-2280, 1993.

MEYER, W. et al. Molecular typing of IberoAmerican Cryptococcus neoformans isolates. Emerg. Infect. Dis., v. 9, p. 189-195, 2003.

MIFSUD, E. J.; TAN, A. C.; JACKSON, D. C. TLR Agonists as Modulators of the Innate Immune Response and Their Potential as Agents Against Infectious Disease. Front Immunol. v. 5, p. 79, 2014.

MILAM, J. E. et al. Modulation of the pulmonary type 2 T-cell response to Cryptococcus neoformans by intratracheal delivery of a tumor necrosis factor alpha-expressing adenoviral vector. Infect Immun. v. 75, n. 10, p. 4951-4958, 2007.

MITCHELL, T. G. et al. Environmental niches for Cryptococcus neoformans and Cryptococcus gattii, ASM press, p. 237-260, 2011. 
MITCHELL, T. G.; PERFECT, J. R. Cryptococcosis in the era of AIDS - 100 years after the discovery of Cryptococcus neoformans. Clin. Microbiol. Rev., v. 8, p. 515-548, 1995.

MONARI, C. et al. Cryptococcus neoformans capsular glucuronoxylomannan induces expression of fas ligand in macrophages. J Immunol. v. 174, p. 3461-8, 2005.

MORROW, C. A.; FRASER, J. A. Is the nickel-dependent urease complex of Cryptococcus the pathogen's Achilles' heel? MBio. v. 4, p. e00408-e00413, 2013.

MURPHY, J. W. et al. Antigen-induced protective and nonprotective cell-mediated immune components against Cryptococcus neoformans. Infection and Immunity, v. 66, p. 2632-2639, 1998.

MUTH, S. M.; MURPHY, J. W. Effects of immunization with Cryptococcus neoformans cells or cryptococcal culture filtrate antigen on direct anticryptococcal activities of murine T lymphocytes. Infect Immun, v. 63, n. 5, p. 1645-51, May 1995.

NELSON, B. N.; HAWKINS, A. N.; WOZNIAK, K. L. Pulmonary Macrophage and Dendritic Cell Responses to Cryptococcus neoformans. Front Cell Infect Microbiol, v. 10, p. 37, Feb 112020.

NOSANCHUK, J. D.; CASADEVALL, A. The contribution of melanin to microbial pathogenesis. Cellular Microbiology, v. 5, p. 203-223, 2003.

O'MEARA, T. R.; ALSPAUGH, J. A. The Cryptococcus neoformans capsule: A sword and a shield. Clin. Microbiol. Rev., v. 25, n. 3, p. 387-408, 2012.

O'HALLORAN, J.A.; POWDERLY, W.G.; SPEC, A. Cryptococcosis today: It is not all about HIV infection. Current clinical microbiology reports, v. 4, p. 88-95, 2017.

OLDENBURG, M. et al. TLR13 recognizes bacterial 23S rRNA devoid of erythromycin resistance-forming modification. Science. v. 337, p. 1111-5, 2012.

OLIVARES, L. R. et al. Genotyping of Mexican Cryptococcus neoformans and C. gattii isolates by PCR-fingerprinting. Med. Mycol., v. 47, p. 713-721, 2009.

O'NEILL, L. A.; BOWIE, A. G. The family of five: TIR-domain-containing adaptors in Toll-like receptor signalling. Nat. Rev. Immunol. v. 7, p. 353-364, 2007.

OPITZ, B. et al. Toll-like receptor-2 mediates Treponema glycolipid and lipoteichoic acid-induced NF-kappaB translocation. J Biol Chem. 2001;276:22041-7.

PÅLSSON-MCDERMOTT, E. M.; O'NEILL, L. A. Building an immune system from nine domains. Biochem Soc Trans. v. 35, n. 6, p. 1437-44, Dec 2007.

PAPON, N.; BOUGNOUX, M.-E.; D'ENFERT, C. Tracing the Origin of Invasive Fungal Infections. Trends Microbiol. v. 28, n. 4, p. 240-242, 2020.

PARK, B. J. et al. Estimation of the current global burden of cryptococcal meningitis among persons living with HIV/AIDS. AIDS, v. 23, p. 525-30, 2009. 
PATIN, E.C.; THOMPSON, A.; ORR, S. J. Pattern Recognition Receptors in Fungal Immunity. In Seminars in Cell \& Developmental Biology. Elsevier. v. 89, p. 24-33, 2019.

PERFECT, J. R. et al. Clinical practice guidelines for the management of cryptococcal disease: 2010 update by the infectious diseases society of america. Clin. Infect. Dis. v. 50, p. 291-322, 2010.

PERFECT, J. R. et al. The Management of Cryptococcal Disease. IDSA endorsed. v. 50, p. 291-322, 2010.

PERFECT, J. R.; BICANIC, T. Cryptococcosis diagnosis and treatment: What do we know now. Fungal Genet. Biol. v. 78, p. 49-54, 2015.

PERFECT, J. R.; CASADEVALL, A. Cryptococcosis. Infect Dis Clin North Am., v. 16, p. 837-74, v-vi, Dec 2002.

PFALLER, M. A.; DIEKEMA, D. J. Epidemiology of invasive mycoses in North America. Crit Rev Microbiol, v. 36, p. 1-53, 2010.

PFEIFFER, T. J.; ELLIS, D. H. Environmental isolation of Cryptococcus neoformans var. gattii from Eucalyptus tereticornis. J. Med. Vet. Mycol., v. 30, p. 407-408, 1992.

PHAN, Q. T. et al. Als3 is a Candida albicans invasin that binds to cadherins and induces endocytosis by host cells. PLoS Biol. v. 5, p. 3, 2007.

PIKMAN, R.; BEN-AMI, R. Immune modulators as adjuncts for the prevention and treatment of invasive fungal infections. Immunotherapy, v. 4, n. 12, p. 1869-82, Dec 2012.

PINTO, A. R. et al. DNA-based vaccination against murine paracoccidioidomycosis using the gp43 gene from Paracoccidioides brasiliensis. Vaccine. v. 18, p. 3050-58, 2000.

POLESELlO, V. et al. Candida Infections and Human Defensins. Protein Pept. Lett., v. 24, n. 8, p. 747-756, 2017.

PRAJEETH, C. K. et al. The synthetic TLR2 agonist BPPcysMPEG leads to efficient cross-priming against co-administered and linked antigens. Eur J Immunol, v. 40, p. 1272-83, 2010.

RAJASINGHAM, R. et al. Global burden of disease of HIV-associated cryptococcal meningitis: an updated analysis. Lancet Infect Dis, v. 17, n. 8, p. 873-81, 2017.

REDLICH, S. et al. Toll-like receptor stimulation increases phagocytosis of Cryptococcus neoformans by microglial cells. J Neuroinflammation. v. 10, p. 71, Jun 5 2013.

REOLON, A.; PEREZ, L. R. R.; MEZZARI, A. Prevalência de Cryptococcus neoformans nos pombos urbanos da Cidade de Porto Alegre, Rio Grande do Sul. Jornal Brasileiro de Patologia e Medicina Laboratorial, v. 40, n. 5, p. 293- 298, 2004.

ROMANI, L. Immunity to fungal infections. Nat. Rev. Immunol. v. 11, n. 4, p. 275, 2011. 
ROSADINI, C. V.; KAGAN, J. C. Microbial strategies for antagonizing Toll-likereceptor signal transduction. Curr Opin Immunol, v. 32, p. 61-70, Feb 2015.

RUMA-HAYNES, P.; BROWNLEE, A. G.; SORRELL, T. C. A rapid method for detecting extracellular proteinase activity in Cryptococcus neoformans and a survey of 63 isolates. J Med Microbiol, v. 49, p. 733-7, 2000.

SABIITI, W.; MAY, R. C. Mechanisms of Infection by the Human Fungal Pathogen Cryptococcus neoformans. Future Microbiol. v. 7, p. 1297-1313, 2012.

SALGADO, C. L. et al. Pam3CSK4 adjuvant given intranasally boosts anti-Leishmania immunogenicity but not protective immune responses conferred by LaAg vaccine against visceral leishmaniasis. Microbes Infect. v. 21, n. 7, p. 328-335, 2019.

SANTOS, E.; LEVITZ, S. M. Fungal vaccines and immunotherapeutics. Cold Spring Harb. Perspect. Med. v. 4, p. 11, 2014.

SATO, M. et al. Direct binding of Toll-like receptor 2 to zymosan, and zymosan-induced NF-kappa B activation and TNF-alpha secretion are down-regulated by lung collectin surfactant protein A. J Immunol. v. 171, n. 1, p. 417-25, Jul 2003.

SAVILLE, S. P. et al. Efficacy of a genetically engineered Candida albicanstet-NRG1 strain as an experimental live attenuated vaccine against hematogenously disseminated candidiasis. Clin Vaccine Immunol. v. 16, p. 430-432, 2009.

SCHENK, M.; BELISLE, J. T.; MODLIN, R. L. TLR2 Looks at Lipoproteins. Immunity. v. 31, n. 6, p. 847-849, 2009.

SCHMIDT, C. S. et al. NDV-3, a recombinant alum-adjuvanted vaccine for Candida and Staphylococcus aureus, is safe and immunogenic in healthy adults. Vaccine. v. 30, p. 52, 2012.

SCHOFFELEN, T. et al. Cryptococcus gattii induces a cytokine pattern that is distinct from other cryptococcal species. PLoS One, v. 8, p. e55579, 2013.

SCHULZE, B. et al. CD4 ${ }^{+} \mathrm{FoxP}^{+}$regulatory $\mathrm{T}$ cells suppress fatal $\mathrm{T}$ helper 2 cell immunity during pulmonary fungal infection. Eur. J. Immunol., v. 44, p. 3596-3604, 2014.

SEIDER, K. et al. Interaction of pathogenic yeasts with phagocytes: survival, persistence and escape. Current Opinion in Microbiology, v. 13, p. 392-400, 2010.

SEVILLA, M. J. et al. A Fungicidal Monoclonal Antibody Protects against Murine Invasive Candidiasis. Infect. Immun. v. 74, p. 3042-3045, 2006.

SHAPIRO, S. et al. Immunoglobulin $G$ monoclonal antibodies to Cryptococcus neoformans protect mice deficient in complement component C3. Infect Immun, v. 70, n. 5 , p. 2598-2604, 2002. 
SHAPOURI-MOGHADDAM, A. et al. Macrophage plasticity, polarization, and function in health and disease. J Cell Physiol, v. 233, n. 9, p. 6425-6440, Sep 2018.

SHIBATA, K. I. et al. The N-terminal lipopeptide of a 44-kDa membrane-bound lipoprotein of Mycoplasma salivarium is responsible for the expression of intercellular adhesion molecule-1 on the cell surface of normal human gingival fibroblasts. $\mathbf{J}$. Immunol. v. 165, p. 6538-6544, 2000.

SHOHAM, S. et al. Toll-like receptor 4 mediates intracellular signaling without TNF- $\alpha$ release in response to Cryptococcus neoformans polysaccharide capsule. J. Immunol. v. 166, p. 4620-4626, 2001.

SINGH, A. et al. Factors required for activation of urease as a virulence determinant in Cryptococcus neoformans. MBio. v. 4, p. e00220-13, 2013.

SLOAN, D. et al. Treatment of acute cryptococcal meningitis in HIV infected adults, with an emphasis on resource-limited settings. Cochrane Database Syst Rev. v. 8, n. 4, p. CD005647, 2008.

SORRELL, T. C. Cryptococcus neoformans variety gattii. Med Mycol, v. 39, p. 155-68, 2001.

SPECHT, C. A. et al. Protection against Experimental Cryptococcosis following Vaccination with Glucan Particles Containing Cryptococcus Alkaline Extracts. MBio. v. 6, n. 6, p. e01905-01915, 2015.

SPECHT, C. A. et al. Vaccination with Recombinant Cryptococcus Proteins in Glucan Particles Protects Mice against Cryptococcosis in a Manner Dependent upon Mouse Strain and Cryptococcal Species. mBio, v. 8, p. e01872-17, 2017.

SPELLBERG, B. J. et al. Efficacy of the anti-Candida rAls3p-N or rAls1p-N vaccines against disseminated and mucosal candidiasis. J Infect Dis. v. 194, p. 256-260, 2006.

STEPHEN, C. et al. British Columbia: Multispecies outbreak of cryptococcosis on southern Vancouver Island, British Columbia. The Canadian Veterinary Journal, v. 43, p. 792-794, 2002.

Stop neglecting fungi. Nat Microbiol, v. 2, p. 17120, Jul 25, 2017.

TAKEDA, K.; KAISHO, T.; AKIRA, S. Toll-like receptors. Annu. Rev. Immunol. v. 21, p. 335-376, 2003.

TAYLOR, P. R. et al. Dectin-1 is required for $\beta$-glucan recognition and control of fungal infection. Nat Immunol. v. 8, n. 1, p. 31-38, 2007.

TAYLOR, L. H.; LATHAM, S. M.; WOOLHOUSE, M. E. J. Risk factors for human disease emergence. Philos. Trans. R. Soc. Lond. B Biol. Sci., v. 356, p. 983-989, 2001.

TEIXEIRA, P. A. C. et al. Mannoprotein MP84 mediates the adhesion of Cryptococcus neoformans to epithelial lung cells. Frontiers in Cellular and Infection Microbiology, v. 4, p. 106, 2014. 
THAK, E. J. et al. Core N-Glycan Structures Are Critical for the Pathogenicity of Cryptococcus neoformans by Modulating Host Cell Death. mBio. v. 11, n. 3, p. e0071120, 2020.

THOMA-USZYNSKI, S. et al. Activation of toll-like receptor 2 on human dendritic cells triggers induction of IL-12, but not IL-10. J Immunol, v. 165, p. 3804-10, 2000.

THOMPSON, A. L.; STAATS, H. F. Cytokines: the future of intranasal vaccine adjuvants. Clin Dev Immunol, v. 2011, p. 289597, 2011.

TOROSANTUCCI, A. et al. Protection by Anti-Beta-Glucan Antibodies Is Associated with Restricted Beta-1,3 Glucan Binding Specificity and Inhibition of Fungal Growth and Adherence. PLoS ONE. v. 4, p. e5392, 2009.

TRILLES, L. et al. Regional pattern of the molecular types of Cryptococcus neoformans and Cryptococcus gattii in Brazil. Mem. Inst. Oswaldo Cruz, v. 103, p. 455-462, 2008.

TUCKER, S. C.; CASADEVALL, A. Replication of Cryptococcus neoformans in macrophages is accompanied by phagosomal permeabilization and accumulation of vesicles containing polysaccharide in the cytoplasm. Proc. Natl. Acad. Sci. U.S.A., v. 99. p. 3165-3170, 2002.

UEMATSU, S.; AKIRA, S. Toll-Like receptors (TLRs) and their ligands. Handb Exp Pharmacol. p. 1-20, 2008.

UENO, K. et al. Cryptococcus gattii alters immunostimulatory potential in response to the environment. PLOS ONE. v. 14, n. 8, p. e0220989, 2019.

UENO, K. et al. Dendritic cell-based immunization ameliorates pulmonary infection with highly virulent Cryptococcus gattii. Infect Immun. v. 83, n. 4, p. 1577-1586, 2015.

UENO, K. et al. Immunization with Antigen-Pulsed Dendritic Cells Against Highly Virulent Cryptococcus gattii Infection: Analysis of Cytokine-Producing $\mathrm{T}$ Cells. Methods Mol Biol, v. 1625, p. 327-339, 2017.

UPTON, A. et al. First Contemporary Case of Human Infection with Cryptococcus gattii in Puget Sound: Evidence for Spread of the Vancouver Island Outbreak. Journal of Clinical Microbiology, v. 45, p. 3086-3088, 2007.

VAN PAASSEN, J. et al. Emerging aspergillosis by azole-resistant Aspergillus fumigatus at an intensive care unit in the Netherlands, 2010 to 2013. Euro Surveill, v. 21, n. 30, Jul 282016.

VANBREUSEGHEM, R.; TAKASHIO, M. An atypical strain of Cryptococcus neoformans (San Felice) Vuillemin 1894. II. Cryptococcus neoformans var. gattii var. nov. Ann Soc Belges Med Trop Parasitol Mycol, v. 50, p. 695-702, 1970.

VAUTIER, S.; MACCALLUM, D. M.; BROWN, G. D. C-type lectin receptors and cytokines in fungal immunity. Cytokine. v. 58, p. 89-99, 2012. 
VECCHIARELLI, A. et al. Downregulation by cryptococcal polysaccharide of tumor necrosis factor alpha and interleukin-1 beta secretion from human monocytes. Infect Immun, v. 63, n. 8, p. 2919-2923, Aug 1995.

VIDARSSON, G.; DEKKERS, G.; RISPENS, T. IgG subclasses and allotypes: from structure to effector functions. Front Immunol, v. 5, p. 520, Oct 202014.

VIGNALI, D. A.; COLLISON, L. W.; WORKMAN, C. J. How regulatory T cells work. Nat Rev Immunol, v. 8, p. 523-32, 2008.

WALSH, N. M. et al. Characterization of C-type lectins reveals an unexpectedly limited interaction between Cryptococcus neoformans spores and Dectin-1. PLOS ONE. v. 12, n. 3, p. e0173866, 2017.

WANG, Y. et al. A Heat-Killed Cryptococcus Mutant Strain Induces Host Protection against Multiple Invasive Mycoses in a Murine Vaccine Model. mBio, v. 10, n. 6, p. e02145-19, Nov 2019.

WEIR, G. M. et al. Combination of poly I:C and Pam3CSK4 enhances activation of B cells in vitro and boosts antibody responses to protein vaccines in vivo. PLoS ONE. v. 12, p. e0180073, 2017.

WIESNER, D. L. et al. Regulatory T Cell Induction and Retention in the Lungs Drives Suppression of Detrimental Type 2 Th Cells During Pulmonary Cryptococcal Infection. J Immunol, v. 196, n. 1, p. 365-374, Jan 12016.

WOZNIAK, K. L.; HARDISON, S. E.; KOLLS, J. K.; WORMLEY, F. L. JR. Role of IL-17A on Resolution of Pulmonary C. neoformans Infection. PLoS ONE, v. 6, n. 2, p. e17204, Feb 172011.

WRIGHT, L. et al. Metabolites released by Cryptococcus neoformans var. neoformans and var. gattii differentially affect human neutrophil function. Microbes Infect, v. 4, n. 14, p. 1427-38, Nov 2002.

YAUCH, L. E. et al. Involvement of CD14, Toll-like receptors 2 and 4, and MyD88 in the host response to the fungal pathogen Cryptococcus neoformans in vivo. Infect. Immun. v. 72, p. 5373-5382, 2004.

ZENG, W. et al. Highly immunogenic and totally synthetic lipopeptides as selfadjuvanting immunocontraceptive vaccines. J Immunol, v. 169, p. 4905-12, 2002.

ZHENG, M. et al. CD4 T cell-independent DNA vaccination against opportunistic infections. J Clin Invest. v. 115, p. 3536-44, 2005.

ZHU, J.; YAMANE, H.; PAUL, W. E. Differentiation of effector CD4 T cell populations. Annu Rev Immunol. v. 28, p. 445-489, 2010. 
APÊNDICES 


\section{Apêndice I}

Título: Pro-inflammatory response ensured by LPS and Pam3CSK4 in RAW 264.7 cells did not improve a fungistatic effect on Cryptococcus gattii infection

Autores: Gabriela Yamazaki de Campos, Raquel Amorim Oliveira, Patrícia Kellen Martins Oliveira-Brito, Maria Cristina Roque-Barreira, Thiago Aparecido da Silva Periódico: PeerJ, 2020. In press. 


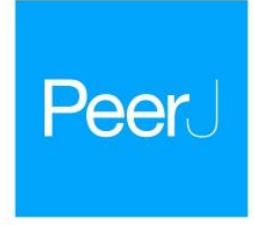

Q1

\section{Please only ANNOTATE the proof. Do not edit the PDF. If multiple authors will review this PDF, please return one file containing all corrections.}

Submitted 9 June 2020 Accepted 13 October 2020 Published TBD

Corresponding author Thiago Aparecido da Silva, sthiagoap@usp.br, sthiagoap@gmail.com Academic editor Hector Mora-Montes Additional Information and Declarations can be found on page 15

DOI 10.7717/peerj.10295

(c) Copyright

2020 de Campos et al.

Distributed under

Creative Commons CC-BY 4.0

\section{Pro-inflammatory response ensured by LPS and Pam3CSK4 in RAW 264.7 cells did not improve a fungistatic effect on Cryptococcus gattii infection}

Gabriela Yamazaki de Campos, Raquel Amorim Oliveira,

Patrícia Kellen Martins Oliveira-Brito, Maria Cristina Roque-Barreira and Thiago Aparecido da Silva

Department of Cell and Molecular Biology and Pathogenic Bioagents, Ribeirāo Preto Medical School, University of São Paulo, Ribeirão Preto, Sao Paulo, Brazil

\section{ABSTRACT}

Background. The macrophage lineage is characterized by plasticity due to the acquisition of distinct functional phenotypes, and two major subsets are evaluated; classical M1 activation (strong microbicidal activity) and alternative M2 activation (immunoregulatory functions). The M1 subset expresses inducible nitric oxide synthase (iNOS), which is a primary marker to identify these cells, whereas M2 macrophages are characterized by expression of Arginase-1, found in inflammatory zone 1 (Fizz1), chitinase-like molecule (Ym-1), and CD206. The micro-environmental stimuli and signals in tissues are critical in the macrophage polarization. Toll-like receptors (TLR) ligands, such as lipopolysaccharide (LPS), palmitoyl-3-cysteine-serine-lysine-4 (Pam3CSK4), and ArtinM (mannose-binding lectin) are inductors of M1 subset. The impact of TLR2 and TLR4 signals to fight against Cryptococcus gattii infection is unknown, which is a fungal pathogen that preferentially infects the lung of immunocompetent individuals. The macrophages initiate an immune response to combat the $C$. gattii, then we evaluated in RAW 264.7 cell the effect of TLR2 and TLR4 agonists on the macrophage polarization dynamic and the impact on the growth of C. gattii.

Methods and Results. We demonstrated that P3C4, LPS, and ArtinM induced an increase in the levels of iNOS transcripts in RAW 264.7 cells, whereas the relative expression of arginase-1, Ym-1, and Fizzl was significantly increased in the presence of IL-4 alone. The effects of TLR2 and TLR4 agonists on repolarization from the M2 to M1 subset was evaluated, and the first stimulus was composed of IL- 4 and, after 24 $\mathrm{h}$ of incubation, the cells were submitted to a second stimulus of P3C4, LPS, ArtinM, or Medium. These TLR agonists induced the production of TNF- $\alpha$ in polarized RAW 264.7 cells to the M2 subset, moreover the measurement of M1/M2 markers using qRT-PCR demonstrated that a second stimulus with LPS for $24 \mathrm{~h}$ induced a significant augmentation of levels of iNOS mRNA. This impact of TLR2 and TLR4 agonists in the activation of the RAW 264.7 macrophage was assayed in the presence of C. gattii, the macrophages stimulated with TLR2 and TLR4 agonists for $24 \mathrm{~h}$ and co-cultured with C. gattii, as a second stimulus, reached high levels of TNF- $\alpha$ even after incubation with different concentrations of $C$. gattii. The activation of RAW 264.7 cells induced by TLR2 and TLR4 agonists favored the phagocytosis of C. gattii and inhibited the growth of yeast in the early period of infection. However, RAW 264.7 cells incubated with $C$. 
gattii in the presence of TLR 2 and TLR4 agonists did not result a significant difference in the colony forming unit (CFU) assay in the early period of C. gattii infection, compared to negative control.

Conclusion. Polarized RAW 264.7 cells to the M1 subset with TLR2 and TLR4 agonists did not inhibit the growth of C. gattii, whereas robust immunity was identified that could dysregulate host tolerance to this pathogen.

Subjects Cell Biology, Mycology, Immunology, Infectious Diseases

Keywords Macrophage polarization, LPS, Pam3CSK4, TLR, Cryptococcus gattii, RAW 264.7 cells

\section{INTRODUCTION}

The multiple functions of macrophages in homeostasis and inflammation demonstrate that these cells play a central role in the modulation of immunity response that may be critical in the success of host defense against different pathogens (Shapouri-Moghaddam et al., 2018; Sica \& Mantovani, 2012). The macrophage lineage is characterized by plasticity due to the acquisition of distinct functional phenotypes, and two major subsets are frequently evaluated; classical M1 activation and alternative M2 activation. These phenotypes are influenced by micro-environmental stimuli and signals that they encounter in tissues, which determine the efficacy of polarized macrophages in maintaining homeostasis (Shapouri-Moghaddam et al., 2018; Wang, Liang \& Zen, 2014). The main stimuli associated with the induction of M1 macrophages are tumor necrosis factor-alfa (TNF- $\alpha$ ), interferongamma (IFN- $\gamma$ ), and lipopolysaccharide (LPS), whereas the presence of interleukin (IL) 4 and IL-10 mediate the M2 macrophages (de Sousa, Da Costa Vasconcelos \& Quaresma, 2019). High levels of proinflammatory cytokines accompanied by high production of reactive nitrogen and oxygen intermediates belong to the $\mathrm{Ml}$ phenotype and ensure strong microbicidal and tumoricidal activity (Davis et al., 2013; Klar et al., 2018; Zhu et al., 2017). In addition, the M1 subset expresses inducible nitric oxide (NO) synthase (iNOS), which is a primary marker for detecting the response of these cells in specific sites (Davis et al., 2013; Klar et al., 2018; Zhu et al., 2017). In contrast, M2 macrophages are involved in tissue remodeling and also have immunoregulatory functions (Gordon \& Martinez, 2010), and the cell expression markers are characterized by Arg-1, found in inflammatory zone 1 (Fizzl), chitinase-like molecule (Ym1), and CD206 (Murray \& Wynn, 2011; Rath et al., 2014). The unbalance of the M1/M2 phenotype and number and distribution of macrophages contribute to tissue damage and pathology during infections (Bashir et al., 2016). Toll-like receptors (TLR) ligands, such as LPS (TLR4 agonist), palmitoyl-3-cysteine-serine-lysine-4 (Pam3CSK4; TLR2 agonist), and ArtinM (mannose-binding lectin; TLR2/CD14 agonist) are greater inductors of Ml macrophages (daSilva et al., 2017), and these TLR agonists can favor a persisting pro-inflammatory response that contributes to the alteration of host tolerance (Butcher et al., 2018). This capacity of TLR signaling is supported by the finding that M2 macrophages can be re-polarized into macrophages with M1 phenotype following exposure to TLR ligands (Mylonas et al., 2009; Stout et al., 2005). 
Peer」

The role of TLR signaling is already reported to control several fungal infections (Netea et al., 2006); and previous study indicate that TLR4 and TLR9 signals can be involved in the pro-inflammatory response induced by Cryptococcus gattii (Schoffelen et al., 2013). C. gattii, a causative agent of cryptococcosis, is a fungal pathogen that preferentially infects the pulmonary tissue of immunocompetent individuals, and lung-resident macrophages initiate an immune response to combat the C. gattii yeast or desiccated basidiospores that reach the tissue (Ngamskulrungroj et al., 2012). However, the modulation of NO production by macrophages occurs via a major capsular component in C. gattii called glucuronoxylomannan (GXM), that can be recognized by TLR2 (Fonseca et al., 2010). In addition, the involvement of TLR2 and TLR4 for host defense against cryptococcosis has been studied in relation to Cryptococcus neoformans infection, for which there is no consensus regarding the contributions of TLR2 and TLR4 to immunity response during the establishment of C. neoformans infection (Biondo et al., 2005; Nakamura et al., 2006; Yauch et al., 2004). On the other hand, a previous study demonstrated that macrophage polarization has plasticity to match the changes in the cytokine environment, and the maintenance of Ml macrophages upon IFN- $\gamma$ stimulus favored the growth inhibition of C. neoformans (Davis et al., 2013). Therefore, the present work evaluated in murine macrophage cell line RAW 264.7 the effects of TLR2 and TLR4 agonists on the macrophage polarization dynamic and the impact on the growth of C. gattii.

We found that the RAW 264.7 macrophage was polarized to the M1 phenotype in response to Pam3CSk4, LPS, and ArtinM, whereas IL-4 induced the M2 macrophage. RAW 264.7 cells previously incubated with IL- 4 had high levels of TNF- $\alpha$ after a second stimulus with TLR2 and TLR4 agonists, and the repolarization from M2 to M1 occurred via TLR4 signal. Pam3CSk4 and LPS-stimulated RAW 264.7 cells maintain high levels of TNF- $\alpha$ after a second stimulus with IL-4, demonstrating the persistence of the proinflammatory response induced by TLR2 and TLR4 agonists. However, RAW 264.7 cells polarized to M1 subset by TLR2 and TLR4 signals did not ensure the growth inhibition of C. gattii. Therefore, the prevalence of M1 macrophages polarized to the outcome of C. gattii infection should be balanced in therapeutic strategies evaluated.

\section{MATERIALS \& METHODS \\ RAW 264.7 cell line and Cryptococcus gattii}

The peritoneal macrophage cell line, RAW 264.7, was routinely grown in RPMI 1640 (GE Healthcare; Chicago, Illinois, USA) supplemented with $10 \%$ fetal bovine serum (FBS), 4 $\mathrm{mM} \mathrm{L-glutamine,} \mathrm{and} \mathrm{antibiotics} \mathrm{and} \mathrm{these} \mathrm{cells} \mathrm{were} \mathrm{cultured} \mathrm{at} 37^{\circ} \mathrm{C}$ in a humidified atmosphere containing $5 \% \mathrm{CO}$.

C. gattii strain R265 (VGII molecular genotype) was recovered on Sabouraud dextrose agar and incubated at $30^{\circ} \mathrm{C}$ for $24 \mathrm{~h}$. One loopful from a single colony was inoculated in Sabouraud dextrose broth and grown for $24 \mathrm{~h}$ at $30^{\circ} \mathrm{C}$ with constant shaking ( $150 \mathrm{rpm}$ ). Yeast was harvested by centrifugation at $2000 \mathrm{xg}$ for $10 \mathrm{~min}$ at $25^{\circ} \mathrm{C}$, washed in sterile phosphate-buffered saline (PBS), and counted using China ink in a Neubauer chamber The concentration of the yeast in each in vitro infection is described in the figure legend. 
Peer

Macrophage polarization/repolarization in response to Pam3CSK4-

\section{P3C4, LPS, and ArtinM}

Synthetic triacylated lipoprotein (Pam3CSK4-P3C4) was purchased from Invivogen (catalog code: tlrl-pms; San Diego, CA, USA), and LPS was purchased from Sigma (SigmaAldrich, St. Louis, MO, USA). ArtinM was purified as described previously (Da Silva et al., 2020) from the saline extract of Artocarpus heterophyllus (jackfruit) seeds through affinity chromatography with immobilized carbohydrate columns. The endotoxin removal from ArtinM solution was performed as described previously (Da Silva et al., 2020).

RAW 264.7 cells were distributed in a 12-well microplate at a concentration of $1 \times 10^{5}$ cells $/ \mathrm{mL}$. RAW 264.7 cells were incubated with LPS $(0.1 \mu \mathrm{g} / \mathrm{mL})$, P3C4 $(0.1 \mu \mathrm{g} / \mathrm{mL})$, ArtinM $(2.5 \mu \mathrm{g} / \mathrm{mL}), \mathrm{IL}-4(40 \mathrm{ng} / \mathrm{mL})$, or medium alone (Medium). After $24 \mathrm{~h}$ of incubation, the cell culture supernatants were collected to quantify the levels of TNF- $\alpha$ using enzyme-linked immunosorbent assay (ELISA) kits (BD Biosciences, San Diego, CA, USA), and the RNA from macrophages was isolated by TRIzol Reagent (Life Technologies, Carlsbad, CA, USA).

The quantification of transcripts of iNOS and arginase-1 by quantitative reverse transcription polymerase chain reaction (qRT-PCR) in M2 macrophages incubated with TLR2 or TLR4 agonists was performed using RAW 264.7 cells $\left(1 \times 10^{5}\right.$ cells $\left./ \mathrm{mL}\right)$ distributed in a 12-well microplate. Initially, macrophages were incubated with IL-4 $(40 \mathrm{ng} / \mathrm{mL})$, which is an inductor of the M2 phenotype, or Medium, as the first stimulus. After $24 \mathrm{~h}$, the cells were submitted to a second stimulus composed of LPS $(0.1 \mu \mathrm{g} / \mathrm{mL})$, P3C4 $(0.1 \mu \mathrm{g} / \mathrm{mL})$, IL-4 (40 ng/mL), or Medium for an additional $24 \mathrm{~h}$.

Determining the levels of TNF- $\alpha$ in M2 macrophages after stimulation with TLR2 or TLR4 agonists

RAW 264.7 cells $\left(1 \times 10^{4}\right.$ cells $\left./ \mathrm{mL}\right)$ distributed in a 96-well microplate. The first stimulus was composed of LPS $(0.1 \mu \mathrm{g} / \mathrm{mL})$, P3C4 $(0.1 \mu \mathrm{g} / \mathrm{mL})$, ArtinM $(2.5 \mu \mathrm{g} / \mathrm{mL}), \mathrm{IL}-4(10,40$, or $80 \mathrm{ng} / \mathrm{mL}$ ), or Medium. After $24 \mathrm{~h}$ of incubation the levels of TNF- $\alpha$ were measured, and an additional $24 \mathrm{~h}$ of incubation containing a second stimulus was performed as follows: fresh medium; cells previously stimulated with LPS, P3C4, ArtinM, IL-4, or Medium were restimulated with the same stimulus; macrophages polarized to the M2 subset by stimulation with IL- 4 at concentrations of $10 \mathrm{ng} / \mathrm{mL}, 40 \mathrm{ng} / \mathrm{mL}$, and $80 \mathrm{ng} / \mathrm{mL}$ received a second stimulus composed of LPS, P3C4, ArtinM, IL-4, or Medium . The cell culture supernatants were obtained to quantify the levels of TNF- $\alpha$ by ELISA.

Quantification of the levels of TNF- $\alpha$ in response to the effect of IL-4 in RAW 264.7 cells previously incubated with P3C4, LPS, or ArtinM

RAW 264.7 cells $\left(1 \times 10^{4}\right.$ cells $\left./ \mathrm{mL}\right)$ were distributed in a 96-well microplate. The first stimulus was composed of LPS $(0.1 \mu \mathrm{g} / \mathrm{mL})$, P3C4 $(0.1 \mu \mathrm{g} / \mathrm{mL})$, ArtinM $(2.5 \mu \mathrm{g} / \mathrm{mL})$, IL-4 (40 ng/mL), or Medium. After $24 \mathrm{~h}$ of incubation the levels of TNF- $\alpha$ were measured. An additional $24 \mathrm{~h}$ of incubation containing a second stimulus was performed as follows: fresh medium; cells previously stimulated with LPS, P3C4, ArtinM, IL-4, or Medium were restimulated with the same stimulus; macrophages incubated with LPS, P3C4, ArtinM, IL-4, or Medium received a second stimulus composed of IL-4 at concentrations of 10 
$\mathrm{ng} / \mathrm{mL}, 40 \mathrm{ng} / \mathrm{mL}$, and $80 \mathrm{ng} / \mathrm{mL}$. The levels of TNF- $\alpha$ were measured in cell culture supernatants.

Co-culture of $C$. gattii and RAW 264.7 cells stimulated with P3C4, LPS, or ArtinM

The RAW 264.7 cell line $\left(2 \times 10^{4}\right.$ cells $\left./ \mathrm{mL}\right)$ was plated in a 48 -well microplate and rested for $4 \mathrm{~h}$. These cells were incubated with LPS $(0.1 \mu \mathrm{g} / \mathrm{mL})$, P3C4 $(0.1 \mu \mathrm{g} / \mathrm{mL})$, ArtinM $(2.5 \mu \mathrm{g} / \mathrm{mL}), \mathrm{IL}-4(40 \mathrm{ng} / \mathrm{mL})$, or Medium for $24 \mathrm{~h}$. These cells were co-cultured with C. gattii at a concentration of $2 \times 10^{4}$ yeast $/ \mathrm{mL}$, or Medium as a negative control, and these conditions were considered a second stimulus. After $24 \mathrm{~h}$ of incubation, the levels of TNF- $\alpha$ were measured in the cell culture supernatant by ELISA.

In another assay, RAW 264.7 cells $\left(2 \times 10^{4}\right.$ cells $\left./ \mathrm{mL}\right)$ were co-cultured with live or heat-killed yeast of C. gattii at a concentration of $2 \times 10^{3}$ yeast $/ \mathrm{mL}$ in a 48 -well microplate at $37{ }^{\circ} \mathrm{C}$ in a humidified atmosphere containing $5 \% \mathrm{CO}_{2}$. Concomitantly, macrophages received LPS $(0.1 \mu \mathrm{g} / \mathrm{mL})$, P3C4 $(0.1 \mu \mathrm{g} / \mathrm{mL})$, ArtinM $(2.5 \mu \mathrm{g} / \mathrm{mL})$, IL-4 $(40 \mathrm{ng} / \mathrm{mL})$, or Medium. The cell culture supernatant was collected after $24 \mathrm{~h}$ of incubation and the levels of TNF- $\alpha$ were quantified by ELISA.

The measurement of relative expression of iNOS and arginase-1 was performed in RAW 264.7 cells $\left(1 \times 10^{5}\right.$ cells $\left./ \mathrm{mL}\right)$ stimulated with LPS $(0.1 \mu \mathrm{g} / \mathrm{mL})$, P3C4 $(0.1 \mu \mathrm{g} / \mathrm{mL})$, ArtinM $(2.5 \mu \mathrm{g} / \mathrm{mL}), \mathrm{IL}-4(40 \mathrm{ng} / \mathrm{mL})$, or Medium, and concomitantly co-cultured with live yeast of C. gattii $\left(1 \times 10^{5}\right.$ yeast $\left./ \mathrm{mL}\right)$. After $24 \mathrm{~h}$ of incubation at $37^{\circ} \mathrm{C}$ in a humidified atmosphere containing $5 \% \mathrm{CO}_{2}$, the RNA from macrophages was isolated by TRIzol Reagent (Life Technologies, Carlsbad, CA, USA). The quantification of transcripts of iNOS and arginase- 1 by qRT-PCR was performed as described below in the quantitative reverse transcription topic.

Fungistatic effect of RAW 264.7 cells stimulated with P3C4, LPS, or ArtinM on C. gattii

The murine RAW 264.7 cell line at a concentration of $1 \times 10^{5}$ cells $/ \mathrm{mL}$ was distributed in a 24-well microplate and rested for $4 \mathrm{~h}$ at $37^{\circ} \mathrm{C}$ in a humidified atmosphere containing $5 \% \mathrm{CO}_{2}$. Macrophages were stimulated with LPS $(0.1 \mu \mathrm{g} / \mathrm{mL})$, P3C4 $(0.1 \mu \mathrm{g} / \mathrm{mL})$, ArtinM $(2.5 \mu \mathrm{g} / \mathrm{mL}), \mathrm{IL}-4(40 \mathrm{ng} / \mathrm{mL})$, or Medium for $24 \mathrm{~h}$. Then, $2 \times 10^{4}$ yeast $/ \mathrm{mL}$ of C. gattii was added to the culture of previously stimulated macrophages, and the co-culture was incubated for $24 \mathrm{~h}$ at $37^{\circ} \mathrm{C}$ in a humidified atmosphere containing $5 \% \mathrm{CO}_{2}$. C. gattii yeasts were plated in the absence of macrophages, which were considered the control of growth of C. gattii under the same conditions. The monolayer culture was detached and macrophages were lysed using sterile water and the suspension was mixed with supernatant to quantify the growth of C. gattii by the colony forming unit (CFU) assay that was expressed as $\mathrm{CFU} / \mathrm{mL}$

Phagocytosis and antifungal activity of RAW 264.7 cells stimulated with P3C4, LPS, or ArtinM and co-cultured with C. gattii

RAW 264.7 cells at a concentration of $1 \times 10^{4}$ cells $/ \mathrm{mL}$ was distributed in a 24-well microplate and rested for $4 \mathrm{~h}$ at $37^{\circ} \mathrm{C}$ in a humidified atmosphere containing $5 \% \mathrm{CO}_{2}$. 
Peer」

Macrophages were stimulated with LPS $(0.1 \mu \mathrm{g} / \mathrm{mL})$, P3C4 $(0.1 \mu \mathrm{g} / \mathrm{mL})$, ArtinM $(2.5$ $\mu \mathrm{g} / \mathrm{mL})$, IL-4 $(40 \mathrm{ng} / \mathrm{mL})$, or Medium. After $24 \mathrm{~h}$, live yeast of C. gattii $\left(1 \times 10^{5}\right.$ yeast $\left./ \mathrm{mL}\right)$ was added to the culture and the co-culture was incubated for $5 \mathrm{~h}$ at $37^{\circ} \mathrm{C}$. Then, the samples were washed twice with PBS to remove nonadherent yeast and the cells were lysed with sterile water. This suspension was plated onto Sabouraud agar plate for CFU quantification. For antifungal activity assay, once the samples were washed twice with PBS to remove nonadherent yeast a fresh medium was added, and incubation was continued for an addition $5 \mathrm{~h}$. After incubation, cells were lysed with sterile water and the fungal cells were plated onto Sabouraud agar plate for CFU quantification.

Quantitative reverse transcription PCR and cytokine measurement RNA from macrophages stimulated for $24 \mathrm{~h}$ was isolated using the TRIzol Reagent (Life Technologies, Carlsbad, CA, USA), according to the manufacturer's protocol. The total RNA was reverse-transcribed into complementary DNA (cDNA) using an iScript ${ }^{\mathrm{TM}}$ cDNA Synthesis Kit (Bio-Rad). Real-time PCR was performed in $10 \mu \mathrm{L}$ reactions using 2x qPCRBIO SyGreen Mix Separate-ROX (PCRBiosystems; Wayne, PA, USA), cDNA (10-25 ng), and $0.3 \mu \mathrm{M}$ of the primer mix. All reactions were performed on a Bio-Rad CFX96 Real-Time Detection System (Bio-Rad) under the following conditions: $95{ }^{\circ} \mathrm{C}$ for $2 \mathrm{~min}$, and $40 \mathrm{cycles}$ of $95^{\circ} \mathrm{C}$ for $5 \mathrm{~s} / 60^{\circ} \mathrm{C}$ for $30 \mathrm{~s}$. Gene expression was quantified using the $\Delta \Delta \mathrm{Ct}$ method and normalized to $\beta$-actin expression. The PCR primers used were: $\beta$-actin (F-CCTAAGGCCAACCGTGAAAA, R-GAGGCATACAGGGACAGCACA), Ym-1 (F-TCACAGGTCTGGCA ATTCTTCTG, R-ACTCCCTTCTATTGGCCTGTCC), Arginase-1 (F-GTTCCCAGATGTACCAGGATTC, R-CGATGTCTTTGGCAGATATGC), Fizzl (F-CCTGAGATTCTGCCCCAGGAT, R-TTCACTGGGA CCATCAGCTGG), and iNOS2 (F-CCGAAGCAAACATCACATTCA, R-GGTCTAAAGGCTCCGGGCT).

The supernatants were used for the quantification of TNF-a levels by ELISA according to the manufacturer's protocol using Ab pairs purchased from BD Biosciences (Pharmingen, San Diego, CA, USA). Concentrations were determined relative to standard curves prepared from recombinant murine cytokines. Absorbances were read at $450 \mathrm{~nm}$ in a PowerWave X microplate scanning spectrophotometer (BioTek Instruments, Inc.).

\section{Statistical analysis}

Results are presented as means \pm SD. All data were analyzed using GraphPad Prism v.7.0 (GraphPad Software, San Diego, CA, USA). The normality and homogeneity of variance of all statistical determinations were analyzed by the Shapiro-Wilk normality test. For datasets with a non-normal distribution, the Kruskal-Wallis test was used for experiments with three or more groups. Differences between the means of groups were evaluated by one-way ANOVA followed by Tukey's multiple comparisons test or the Kruskal-Wallis test followed by Dunn's multiple comparisons test. Differences at $p<0.05$ were considered statistically significant. 
RESULTS

Role of TLR2 and TLR4 agonists in the polarization and repolarization of RAW 264.7 cells

Macrophage polarization occurs in different sources of macrophages and the microenvironment and innate immune receptors are major inductors in differentiation to M1 or M2 subsets (Mantovani et al., 2004; Wang, Liang \& Zen, 2014). The modulation of M1- and M2-type macrophage polarization can be orchestrated by C. gattii compounds through interactions with receptors on the cell surface (Ueno et al., 2019). In this context, carbohydrates located in the C. gattii capsule can inhibit TLR2 and TLR4 signaling, which is a mechanism to subvert the host immune response. Then, we evaluated the effect of TLR2 and TLR4 agonists on the maintenance of polarized RAW 264.7 cells into the M1 subset over time during C. gattii infection. Initially, we demonstrated that P3C4, LPS, and ArtinM induced a significant production of TNF- $\alpha$ by RAW 264.7 cells after 24 and $48 \mathrm{~h}$ of incubation (Fig. 1A). The impact of TLR2 and TLR4 agonists in M1/M2 polarization was investigated by measuring the mRNA levels of M1/M2 markers, and RAW 264.7 cells stimulated with TLR2 and TLR4 agonists had a significant increase in the levels of iNOS transcripts (Fig. 1B), whereas the relative expression of arginase-1, YM-1, and FIZZ-1 was significantly altered in the presence of IL-4 alone (Figs. 1C-1E).

To understand the potential of TLR2 and TLR4 agonists in the modulation of M2 macrophages, the RAW 264.7 cell line was incubated with different concentrations of IL-4 and, after $24 \mathrm{~h}$ of incubation, the cells were stimulated with P3C4, LPS, or ArtinM. This hypothesis was investigated via the measurement of M1/M2 markers in polarized RAW 264.7 cells to the M2 phenotype that received a second stimulus with TLR2 and TLR4 agonists for $24 \mathrm{~h}$. The transcripts of iNOS and arginase- 1 were quantified by qRT-PCR and only LPS induced a significant augmentation of levels of iNOS mRNA in macrophages (Fig. 2A), whereas the levels of arginase-1 mRNA in macrophages stimulated with P3C4 or LPS had been lower than those incubated with Medium (Fig. 2B). These findings demonstrate that TLR2 and TLR4 agonists can act in macrophage repolarization from the M2 to M1 phenotype.

TNF- $\alpha$ production induced by TLR2 and TLR4 agonists in RAW 264.7 cells is not affected by live yeast of $C$. gattii

Previous studies have reported that $C$. gattii modulates the host immune response using capsule compounds and intracellular proteins released (Fonseca et al., 2010), and innate immune receptors are potential targets in the suppression of the immune response induced by C. gattii. The impact of TLR2 and TLR4 agonists in the activation of the RAW 264.7 cells was assayed in the presence of an inflammatory regulator, such as IL-4, which was evaluated using two different approaches as follows: (i) cells were incubated with IL-4 at different concentrations $(10-80 \mathrm{ng} / \mathrm{mL})$ and were submitted to a second stimulus of P3C4, LPS, or ArtinM (Fig. 3); (ii) cells were stimulated with LPS, P3C4, or ArtinM for $24 \mathrm{~h}$, and a second stimulus with IL-4 (10 to $80 \mathrm{ng} / \mathrm{mL})$ was performed (Fig. S1). In both approaches the production of TNF- $\alpha$ was measured, and we observed that macrophages previously incubated with IL-4 at different concentrations $(10-80 \mathrm{ng} / \mathrm{mL})$ showed high 
Peer」

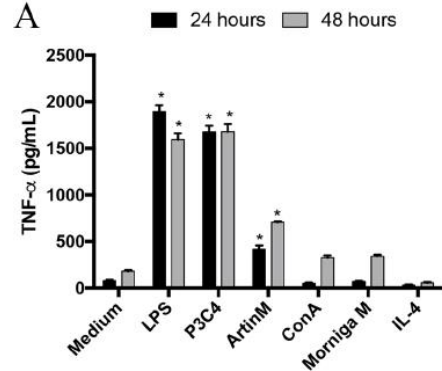

$\mathrm{C}$

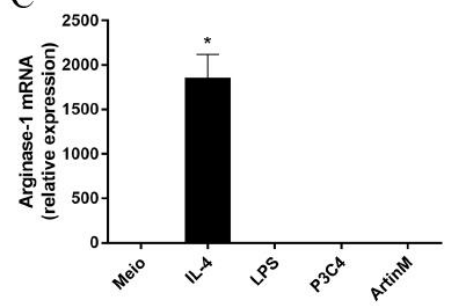

E

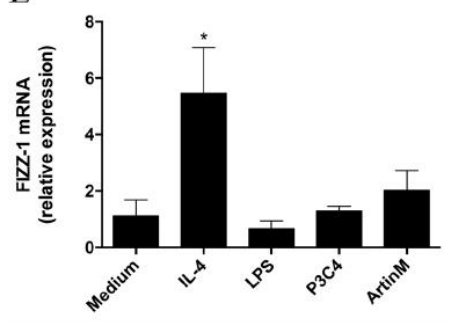

B

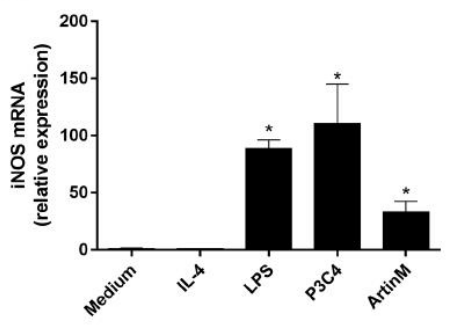

$\mathrm{D}$

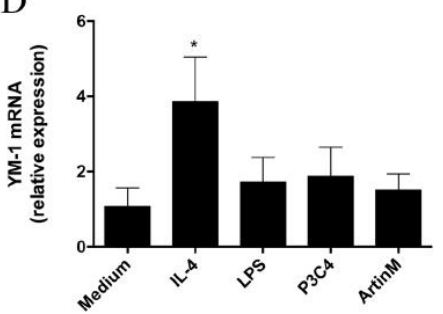

Figure 1 RAW 264.7 cells stimulated with TLR2 and TLR4 agonists differentiated to M1 subset. RAW 264.7 cells at a concentration of $1 \times 10^{5}$ cells $/ \mathrm{mL}$ were incubated with LPS $(0.1 \mathrm{mg} / \mathrm{mL}), \mathrm{P} 3 \mathrm{C} 4$ $(0.1 \mu \mathrm{g} / \mathrm{mL}), \operatorname{ArtinM}(2.5 \mathrm{mg} / \mathrm{mL}), \mathrm{IL}-4$ (40 ng/mL), or medium alone (Medium). (A) After $24 \mathrm{~h}$ of incubation, the levels of TNF-a were measured in the cell culture supernatants by ELISA. (B-E) The RNA samples extracted from these cells were reverse-transcribed into cDNA and analyzed for the expression of iNOS2, Arginase-1, YM-1, and Fizz1 by qRT-PCR. The levels of transcripts and TNF- $\alpha$ in RAW 264.7 cells stimulated with LPS, P3C4, ArtinM, and IL-4 were compared with those of cells in Medium. Data are shown as means $\pm \mathrm{SD}$, and ${ }^{*} p<0.05$, and the difference between groups was evaluated by one-way ANOVA followed by Tukey's multiple comparisons test. Gene expression was quantified by using the $\Delta \Delta \mathrm{Ct}$ method and normalized to $\beta$-actin expression. Full-size DOI: 10.7717/peerj.10295/fig-1 
Peer」

A

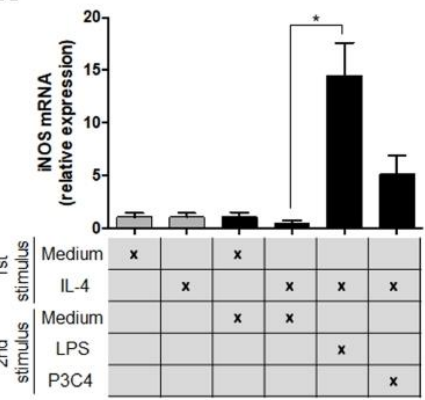

B

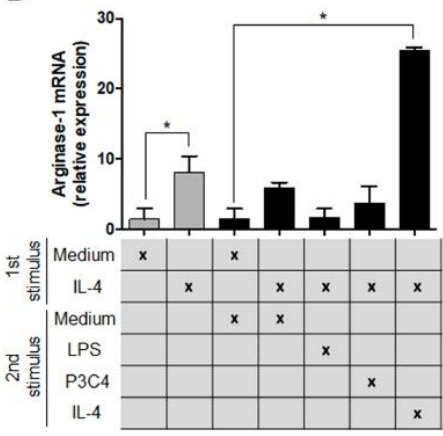

Figure 2 The M2 subset of RAW 264.7 cells was repolarized to the M1 phenotype in the presence of LPS stimulus. RAW 264.7 cells $\left(1 \times 10^{5}\right.$ cells $\left./ \mathrm{mL}\right)$ were incubated with IL-4 $(40 \mathrm{ng} / \mathrm{mL})$ or medium alone (Medium), and the relative expression of iNOS (A) and arginase-1 (B) was measured by RT-PCR after 24 $\mathrm{h}$ of incubation (gray bar). A second stimulus composed of LPS $(0.1 \mathrm{mg} / \mathrm{mL}), \mathrm{P} 3 \mathrm{C} 4(0.1 \mu \mathrm{g} / \mathrm{mL})$, IL-4 ( $40 \mathrm{ng} / \mathrm{mL}$ ), or Medium was performed, and the transcripts for iNOS (A) and arginase-1 (B) were quantified after $24 \mathrm{~h}$ of incubation. The values are expressed as means $\pm \mathrm{SD}$ and ${ }^{*} p<0.05$, according to the Kruskal-Wallis test followed by Dunn's multiple comparisons test.

Full-size DOI: 10.7717/peerj.10295/fig-2

levels of TNF- $\alpha$ after 24 h of incubation with P3C4, LPS, or ArtinM as second stimulus, compared to Medium (Fig. 3, blue, green, and yellow bars). In addition, there was no significant difference in the levels of TNF- $\alpha$ induced by TLR2 and TLR4 agonists between macrophages previously incubated with IL-4 at different concentrations (Fig. 3, blue, green, and yellow bars). In the other hand, the first stimulus with LPS, P3C4, or ArtinM induced high levels of TNF- $\alpha$ in the RAW 264.7 cell after $24 \mathrm{~h}$ of incubation (Fig. S1, black bar), and these levels were reduced after a second stimulus with IL- 4 in a dose-dependent manner (Fig. S1, blue, green, and yellow bars). Taken together, these findings suggest that the TLR2 and TLR4 agonists-activated RAW 264.7 cell induce a proinflammatory response even in the presence of inflammatory regulator.

The immunomodulation induced by TLR agonists in RAW 264.7 cells was also evaluated after co-culture with $C$. gattii yeasts. The macrophages were stimulated with TLR2 and TLR4 agonists in the absence of C. gattii for $24 \mathrm{~h}$ and an additional $24 \mathrm{~h}$ of incubation in the presence of C. gattii. The levels of TNF- $\alpha$ were measured in the culture supernatant, and the cells incubated with TLR2 and TLR4 agonists for $24 \mathrm{~h}$ and co-cultured with $C$. gattii as a second stimulus induced high levels of TNF- $\alpha$ in response to stimulation with LPS and P3C4, compared to the Medium (Fig. 4A). In other assay, the effect of C. gattii on the levels of TNF- $\alpha$ produced was also tested in the RAW 264.7 cells concomitantly stimulated with TLR2 or TLR4 agonists and co-cultured with C. gattii (live or heat-killed yeast), and after $24 \mathrm{~h}$ the levels of TNF- $\alpha$ were measured. The LPS and P3C4-activated RAW 264.7 cells reached high levels of TNF- $\alpha$ even in the presence of C. gattii, and the live yeast of C. gattii did not decrease the production of TNF- $\alpha$ induced by RAW 264.7 cells 
Peer」

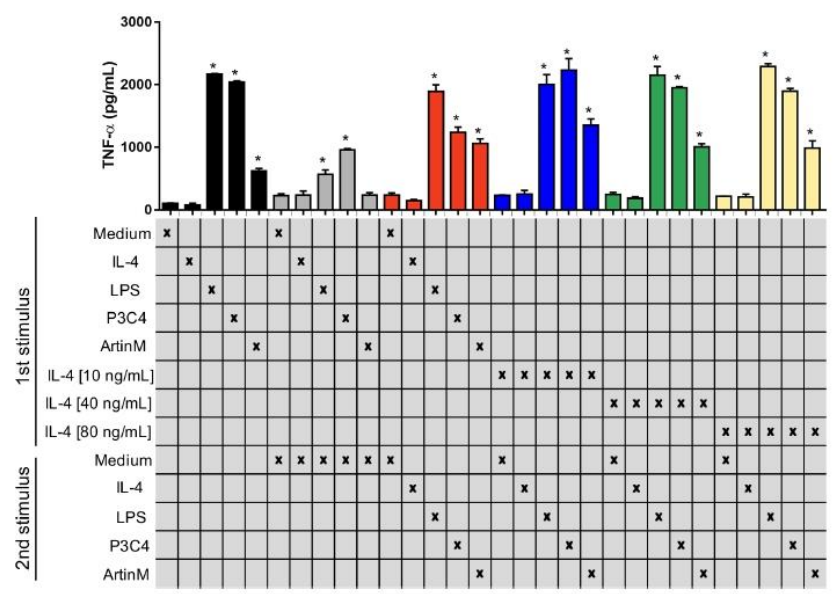

Figure 3 RAW 264.7 macrophages previously incubated with IL-4 began to produce TNF-a in the presence of TLR2 and TLR4 agonists. RAW 264.7 cells $\left(1 \times 10^{4}\right.$ cells $\left./ \mathrm{mL}\right)$ received the first stimulus composed of LPS $(0.1 \mu \mathrm{g} / \mathrm{mL})$, P3C4 $(0.1 \mathrm{mg} / \mathrm{mL})$, ArtinM $(2.5 \mu \mathrm{g} / \mathrm{mL})$, IL-4 $(10,40$, or $80 \mathrm{ng} / \mathrm{mL})$, or medium alone (Medium). After $24 \mathrm{~h}$ of incubation, the levels of TNF-a were measured in the cell culture supernatants (black bar). An additional $24 \mathrm{~h}$ of incubation was done using as a second stimulus as follows: fresh medium (gray bar); (red bar) restimulated with LPS $(0.1 \mu \mathrm{g} / \mathrm{mL})$, P3C4 $(0.1 \mathrm{mg} / \mathrm{mL})$, ArtinM $(2.5$ $\mu \mathrm{g} / \mathrm{mL}$ ), IL-4 (40 ng/mL), or Medium; (blue bar) IL-4 at a concentration of $10 \mathrm{ng} / \mathrm{mL}$; (green bar) IL-4 at a concentration of $40 \mathrm{ng} / \mathrm{mL}$; (yellow bar) IL- 4 at a concentration of $80 \mathrm{ng} / \mathrm{mL}$. The levels of TNF- $\alpha$ were measured in the cell culture supernatants by ELISA. Results are shown as means $\pm \mathrm{SD}$, and ${ }^{*} p<0.05$, according to the Kruskal-Wallis test followed by Dunn's multiple comparisons test. * Compared to the Medium.

Full-size DOI: 10.7717/peerj.10295/fig-3

stimulated with TLR2 and TLR4 agonists (Fig. 4B). However, the levels of TNF- $\alpha$ induced by LPS stimulus had a significant increase in the presence of heat-killed yeast of C. gattii, compared to RAW 264.7 cells co-cultured with or without live yeast of C. gattii (Fig. 4B). Therefore, the improvement in the production of TNF- $\alpha$ by RAW 264.7 cells in response to LPS stimulus occurred by heat-killed yeast of $C$. gattii.

RAW 264.7 cells stimulated with TLR2 and TLR4 agonists had not a fungistatic effect on $C$. gattii infection due the alteration in the balance of iNOS/Arginase-1 expression

Proinflammatory mediators are required in several intracellular pathogen infections and previous studies have reported the importance of proinflammatory immune responses to fight cryptococcosis (Kumaresan, daSilva \& Kontoyiannis, 2017). As LPS and P3C4 modulate RAW 264.7 cells to the M1 phenotype, this study evaluated the co-culture of RAW 264.7 cells with C. gattii in the presence of TLR2 and TLR4 agonists. The macrophages were incubated with LPS, P3C4, ArtinM, or Medium for $24 \mathrm{~h}$, and infection with C. gattii yeasts (1:100 C. gattii/macrophage ratio) was performed. After $24 \mathrm{~h}$ of co-culture, the 
Peer」

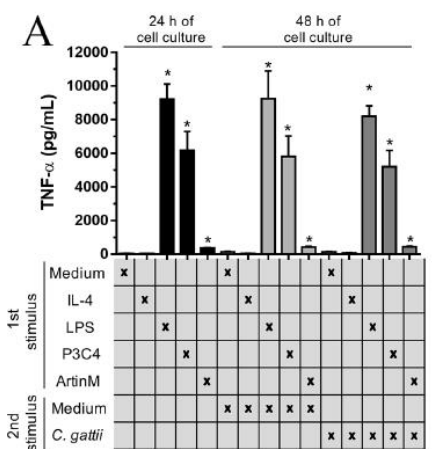

$\mathrm{B}$

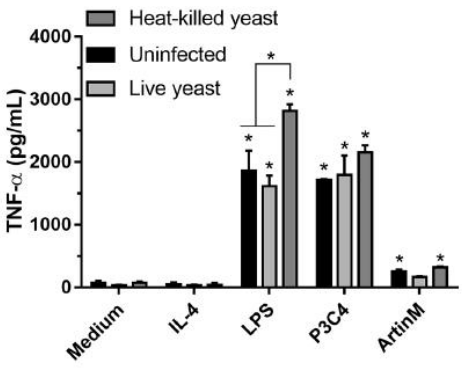

Figure 4 TLR2 and TLR4 agonists induced the production of TNF- $\alpha$ in RAW 264.7 cells co-cultured with C. gattii. (A) The RAW 264.7 cell line $\left(2 \times 10^{4}\right.$ cells/mL $)$ was plated in a 48 -well microplate and incubated with LPS $(0.1 \mathrm{mg} / \mathrm{mL})$, P3C4 $(0.1 \mu \mathrm{g} / \mathrm{mL})$, ArtinM $(2.5 \mathrm{mg} / \mathrm{mL}), \mathrm{IL}-4(40 \mathrm{ng} / \mathrm{mL})$, or medium alone (Medium). After $24 \mathrm{~h}$, RAW 264.7 cells were co-cultured with C. gattii (MOI 1:1) or Medium as a negative control for an additional $24 \mathrm{~h}$ of incubation. (B) RAW 264.7 cells $\left(2 \times 10^{4}\right.$ cells $/ \mathrm{mL}$ ) were a negative control for an additional $24 \mathrm{~h}$ of incubation. (B) RAW 264.7 cells $\left(2 \times 10^{4} \mathrm{cell} / \mathrm{s} / \mathrm{mL}\right.$ ) were
co-cultured with live or heat-killed yeast of $C$. gattii at a concentration of $2 \times 10^{3}$ yeast $/ \mathrm{mL}$ in a 48 -well microplate for $24 \mathrm{~h}$ of incubation. LPS $(0.1 \mu \mathrm{g} / \mathrm{mL})$, P3C4 $(0.1 \mathrm{mg} / \mathrm{mL})$, ArtinM $(2.5 \mu \mathrm{g} / \mathrm{mL})$, IL-4 (40 $\mathrm{ng} / \mathrm{mL}$ ), or Medium were added concomitantly to the co-cultured with C. gattii. (A and B) The levels of TNF-a were performed in the cell culture supernatant by ELISA, and results are shown as means $\pm \mathrm{SD}^{*} p<0.05$, according to the Kruskal-Wallis test followed by Dunn's multiple comparisons test. * Compared to the Medium.

Full-size DOI: 10.7717/peeri.10295/fig-4

growth of C. gattii was quantified by CFUs and the results provided by co-incubation of unstimulated RAW 264.7 cells (Medium) with C. gattii did not significantly differ from those obtained after stimulation with LPS, P3C4, or ArtinM. The C. gattii culture alone in the absence of RAW 264.7 cells (C. gattii alone) was performed as control, and the growth of $C$. gattii yeasts in unstimulated RAW 264.7 cells (Medium) did not differ from those obtained from C. gattii alone (Fig. 5A). The outcome of C. gattii infection was not strongly associated with M1 macrophages polarized by TLR2 and TLR4 agonists.

To understand the effect of C. gattii infection in the polarization of RAW 264.7 cells induced by TLR2 and TLR4 agonists, these cells were stimulated with IL-4, LPS, P3C4, and ArtinM concomitantly or not (uninfected) with live yeast of C. gattii. After $24 \mathrm{~h}$, the mRNA levels of iNOS and arginase-1 were measured by RT-PCR. C. gattii-infected RAW 264.7 cells after stimulation with TLR2 and TLR4 agonists had a significant decrease in the levels of iNOS transcripts compared to uninfected macrophages (Fig. 5B), whereas the relative expression of arginase-1 was significantly augmented in RAW 264.7 cells infected with C. gattii and stimulated with LPS (Fig. 5C). These findings demonstrated that the $C$. gattii infection is able to regulate the iNOS expression induced by TLR2 and TLR4 agonists, which can influence the microbicidal activity of macrophage favoring the growth of yeast. 
Peer」

A
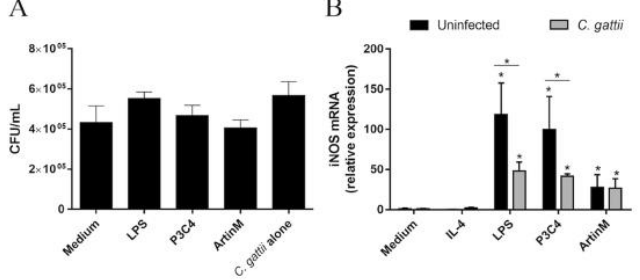

C

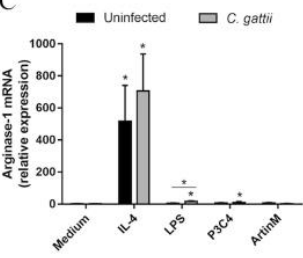

Figure 5 C. gattii growth was not reduced by RAW 264.7 cells incubated with TLR2 and TLR4 agonists due to unbalance of iNOS/Arg-1 expression. (A) $2 \times 10^{4}$ yeast $/ \mathrm{mL}$ of $C$. gattii was added to a culture of RAW 264.7 cells $\left(1 \times 10^{5}\right.$ cells $\left./ \mathrm{mL}\right)$ previously stimulated with LPS $(0.1 \mathrm{mg} / \mathrm{mL})$, P3C4 $(0.1 \mu \mathrm{g} / \mathrm{mL})$, Art$\operatorname{inM}(2.5 \mathrm{mg} / \mathrm{mL}), \mathrm{IL}-4(40 \mathrm{ng} / \mathrm{mL})$, or medium alone (Medium) for $24 \mathrm{~h}$. As a control of the growth of C. gattii, the yeasts were incubated in the absence of macrophages (C. gattii alone). The colony forming unit $(\mathrm{CFU})$ assay was performed using a monolayer culture detached and mixed with supernatant, and the results were expressed as CFU/mL. (B-C) Measurement of relative expression of iNOS and arginase-1 in RAW 264.7 cells $\left(1 \times 10^{5}\right.$ cells $\left./ \mathrm{mL}\right)$ stimulated with LPS $(0.1 \mathrm{mg} / \mathrm{mL})$, P3C4 $(0.1 \mu \mathrm{g} / \mathrm{mL})$, ArtinM $(2.5$ $\mathrm{mg} / \mathrm{mL}), \mathrm{IL}-4(40 \mathrm{ng} / \mathrm{mL})$, or Medium. Moreover, the cells were concomitantly co-cultured with live yeast of $C$. gattii $\left(1 \times 10^{5}\right.$ yeast $\left./ \mathrm{mL}\right)$. After $24 \mathrm{~h}$ of incubation, the RNA from macrophages was extracted for quantification of transcripts of iNOS and arginase-1 by qRT-PCR. (A, B, and C) The values are expressed in means $\pm \mathrm{SD}$, and ${ }^{*} p<0.05$, according to the Kruskal-Wallis test followed by Dunn's multiple comparisons test.

$$
\text { Full-size DOI: 10.7717/peerj.10295/fig-5 }
$$

RAW 264.7 cells stimulated with TLR2 and TLR4 agonists inhibit the growth of $C$. gattii in the early period of infection

This work also investigated the impact of TLR2 and TLR4 agonists in the phagocytic activity of RAW 264.7 cells in the presence of C. gattii. The cells were incubated with IL-4, IFN- $\gamma$, LPS, P3C4, or ArtinM for $24 \mathrm{~h}$ previously the addition of $C$. gattii, and after $5 \mathrm{~h}$ of in vitro infection the non-adherent yeasts were removed. The level of phagocytosis was performed by CFU and the activation of RAW 264.7 cells induced by TLR2 and TLR4 agonists and IFN- $\gamma$ improved the phagocytosis of $C$. gattii, compared to unstimulated macrophages (Medium) (Fig. 6). Then, the capacity of RAW 264.7 cells to control the growth of $C$. gattii in response to stimulation with TLR2 and TLR4 agonists was performed. To evaluated the antifungal activity of macrophages previously stimulated the cells were submitted to conditions described above for phagocytosis assay. Once the non-adherent yeasts were removed, fresh medium was added and incubation was continued for an additional $5 \mathrm{~h}$ and macrophage lysate was plated for CFU determination. The quantification of C. gattii in RAW 264.7 cells previously incubated with medium or IL-4 had a significant increase compared to CFU quantified after phagocytosis (Fig. 6). However, the stimulation of RAW 264.7 cells with IFN- $\gamma$, LPS, P3C4, or ArtinM did not result a significant difference compared to the adherent yeast measured in the phagocytosis assay (Fig. 6). Then, proinflammatory immune response induced in RAW 264.7 cells by TLR2 and TLR4 agonists favors the uptake of C. gattii promoting a control of growth of yeast in the early stage of infection. 
Peer」

A

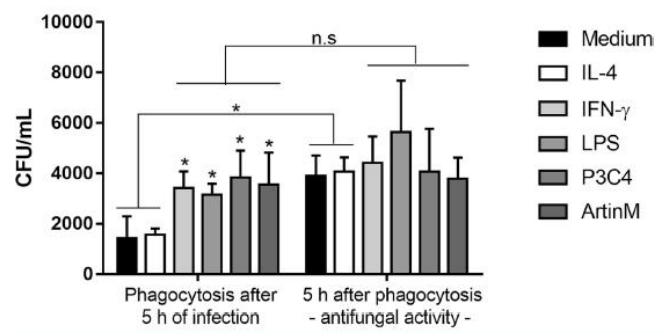

Figure 6 RAW 264.7 macrophages stimulated with TLR2 and TLR4 agonists had improved the phagocytosis and antifungal activity in early period of $C$. gattii infection. RAW 264.7 macrophages (1 $\times 10^{4}$ cells $\left./ \mathrm{mL}\right)$ were stimulated with LPS $(0.1 \mu \mathrm{g} / \mathrm{mL})$, P3C4 $(0.1 \mathrm{mg} / \mathrm{mL}), \operatorname{ArtinM}(2.5 \mu \mathrm{g} / \mathrm{mL}), \mathrm{IL}-4(40$ $\mathrm{ng} / \mathrm{mL}$ ), or Medium for $24 \mathrm{~h}$. Live yeast of C. gattii $\left(1 \times 10^{5}\right.$ yeast $\left./ \mathrm{mL}\right)$ was co-cultured with macrophages for $5 \mathrm{~h}$ at $37^{\circ} \mathrm{C}$. For phagocytosis assay, the nonadherent yeast were removed after washed twice with $\mathrm{PBS}$, and the macrophages lysed were plated onto Sabouraud agar plate for CFU quantification. For $\mathrm{PBS}$, and the macrophages lysed were plated onto Sabouraud agar plate for $\mathrm{CFU}$ quantification. For
antifungal activity, fresh medium was added once nonadherent yeast was removed and an addition $5 \mathrm{~h}$ was antifungal activity, fresh medium was added once nonadherent yeast was removed and an addition $5 \mathrm{~h}$ was
continued to measure the CFU. The values are expressed in means $\pm \mathrm{SD}$, and ${ }^{*} p<0.05$, according to the Kruskal-Wallis test followed by Dunn's multiple comparisons test.

\section{DISCUSSION}

The activation of macrophages in response to TLR agonists, in which LPS and Pam3CSK4 are considered the major inductors of pro-inflammatory mediators, is widely studied (Schlaepfer et al., 2014). Moreover, the capacity of TLR2 and TLR4 agonists in the induction of the M1 phenotype has been investigated in macrophages from different sources (Feng et al., 2020; Kulsantiwong et al., 2017; Wang et al., 2020). However, the impact of TLR2 and TLR4 agonists on the activation of macrophages previously regulated by anti-inflammatory cytokine or C. gattii infection requires further investigation. In this line, the current study adopted the peritoneal macrophage RAW 264.7 cell line to demonstrate that TLR2 (P3C4 and ArtinM) and TLR 4 (LPS) agonists are great inductors of M1 macrophages, and P3C4 and LPS are able to support the production of TNF- $\alpha$ by macrophages upon the presence of immunosuppressor agent. Furthermore, LPS induced repolarization from the M2 to M1 subset. The effect of TLR2 and TLR4 agonists in RAW 264.7 cells ensures the production of high levels of TNF- $\alpha$ in the co-culture with C. gattii. This immunomodulatory activity promoted by TLR2 and TLR4 agonists in macrophages did not control the in vitro C. gattii growth. With the modulation of macrophages to the pro-inflammatory immune response by LPS and P3C4 over time, C. gattii infection did not improve host resistance and could be a trigger to alter host tolerance.

TLR2 and TLR4 are relevant in the detection of fungal components, such as zymosan, Olinked mannans, and fungal DNA (Taghavi et al., 2017). Previous studies have investigated the role of TLR2 and TLR4 signaling in C. neoformans infection, and the absence of TLR2 and TLR4 has been found to compromise the host response (Biondo et al., 2005; Yauch et 
Peer」

al., 2004). Additionally, previous studies have demonstrated that TLR2 and/or TLR4 signals play a limited role in host defense against C. neoformans (Biondo et al., 2005; Nakamura et al., 2006). The role of TLR2 and TLR4 in the control of C. gattii infection have not yet been evaluated, and previous study demonstrated that the blocking TLR4 significantly decreased the production of IL-1 $\beta$ in response to C. gattii stimulation (Schoffelen et al., 2013). Then, TLR2 and TLR4 agonists can be considered in the induction of pro-inflammatory response possibly affected by C. gattii infection. In this context, Fonseca et al. (2010) demonstrated that GXM polysaccharide from serotype B C. gattii efficiently induced the TLR2-mediated response (Fonseca et al., 2010). These authors also found that GXM fractions from C. gattii serotype B strains can elicit NO production by macrophages, suggesting that soluble GXM can favor M1 polarization via TLR2 signaling. Taken together, TLR2 and TLR4 signals, independently of their limited role in host response against cryptococcosis, are useful in the modulation of innate immune response over time during Cryptococcus spp. infection. We selected the mouse macrophage cell line RAW 264.7 to investigate the role of Pam3CSk4, ArtinM (TLR2 agonists), and LPS (TLR4 agonist) in macrophage repolarization for the host response against C. gattii infection. This study evidenced the prevalence of M1 markers in RAW 264.7 cells upon TLR2 and TLR4 stimuli, and previous studies have reported the M1 polarization in macrophages from distinct sources in response to TLR2 and TLR4 agonists (Mantovani et al., 2004; Montoya et al., 2019; Sica \& Mantovani, 2012). The development of the M1 phenotype is critical for controlling C. neoformans infection due to the oxidative burst produced by M1 macrophages, whereas the M2 subset is not antimicrobial against C. neoformans (Arora et al., 2011; Johnston \& May, 2013). In this context, we demonstrated that TLR 2 and TLR4 agonists induced high levels of TNF- $\alpha$ in RAW 264.7 cells previously polarized to the M2 phenotype; moreover, LPS induced macrophage repolarization from the M2 to M1 phenotype. These mechanisms triggered by TLR2 and TLR4 agonists are necessary to fight against the C. neoformans infection, in which Davis et al. (2013) showed that M2 polarized macrophages can re-polarize to the M1 phenotype, maintaining the functional anti-cryptococcal activity (Davis et al., 2013). However, the mechanisms of host resistance to C. gattii infection may not be strictly associated with the M1 macrophages, as there have been no previous studies, to our knowledge, on this topic. We found that the absence of iNOS improves the survival of C. gattii-infected mice (Oliveira-Brito et al., 2020), and the high levels of NO induced by C. gattii mediated the apoptosis of inflammatory cells, compromising the control of cryptococcosis (Chiapello et al., 2008). Therefore, the strength of TLR2 and TLR4 agonists in M1 macrophage polarization should be evaluated carefully in host resistance within each infection model.

This study used TNF- $\alpha$ levels to measure the capacity of TLR2 and TLR4 agonists to modulate the macrophages challenged with distinct stimulus, as TNF- $\alpha$ biosynthesis is strictly related to TLR signaling and the production of TNF- $\alpha$ is a M1 marker currently being evaluated (Arango Duque \& Descoteaux, 2014). The production of TNF- $\alpha$ is useful to understand the effects of TLR2 and TLR4 agonists on the maintenance of pro-inflammatory responses or on macrophage repolarization. The pro-inflammatory response and its mechanisms have been widely studied in C. neoformans infection, and most studies have used immunomodulator agents polarize toward the M1 profile. However, the success in the 
Peer」

balance between pro- and anti-inflammatory responses is an effective way to address the control of cryptococcosis. This hypothesis is supported by the relationship between disease tolerance and resistance, in which the balance between them facilitates efficient pathogen clearance with an acceptable degree of immunopathology (Soares, Teixeira \& Moita, 2017). The interaction of fungal virulence and dysregulated host immune response is associated with the pathogenesis of cryptococcal disease, and C. gattii is a pathogen that causes disease in hosts with weak or robust immunity (Casadevall \& Pirofski, 2003; Casadevall \& Pirofski, 2015; Pirofski \& Casadevall, 2017). This means that the capacity of TLR2 and TLR4 agonists to induce a pro-inflammatory response and reduce the prevalence of M2 macrophages affects host tolerance to C. gattii. In addition, host resistance is not improved with TLR2 and TLR4 agonists against in vitro C. gattii infection based on our results, which showed a deficiency in the fungistatic effect on C. gattii infection by TLR-stimulated macrophages.

\section{CONCLUSIONS}

In conclusion, RAW 264.7 cells stimulated with TLR2 and TLR4 agonists did not experience a fungistatic effect on C. gattii infection, whereas robust immunity was identified that could dysregulate host tolerance to this pathogen. This study provides new perspective on therapeutic strategies with a focus on host resistance and tolerance mechanisms in a balanced manner that could have the potential to improve disease outcomes.

\section{ACKNOWLEDGEMENTS}

We thank Patrícia E. Vendruscolo, Sandra M.O. Thomaz and Érica Vendruscolo for technical support.

\section{ADDITIONAL INFORMATION AND DECLARATIONS}

\section{Funding}

This work was supported by the Fundação de Amparo a Pesquisa do Estado de São Paulo (Grant Numbers 2018/18538-0, 2018/19949-4, 2018/21708-5, and 2016/17037-2), Conselho Nacional de Desenvolvimento Científico e Tecnológico (CNPq) (Grant Number 431853/2018-5). The funders had no role in study design, data collection and analysis, decision to publish, or preparation of the manuscript.

\section{Grant Disclosures}

The following grant information was disclosed by the authors: Fundação de Amparo a Pesquisa do Estado de São Paulo: 2018/18538-0, 2018/19949-4, 2018/21708-5, 2016/17037-2

Conselho Nacional de Desenvolvimento Científico e Tecnológico (CNPq): 431853/2018-5.

\section{Competing Interests}

The authors declare there are no competing interests. 


\section{Author Contributions}

- Gabriela Yamazaki de Campos, Patrícia Kellen Martins Oliveira-Brito and Thiago Aparecido da Silva conceived and designed the experiments, performed the experiments, analyzed the data, prepared figures and/or tables, authored or reviewed drafts of the paper, and approved the final draft.

- Raquel Amorim Oliveira conceived and designed the experiments, performed the experiments, analyzed the data, authored or reviewed drafts of the paper, and approved the final draft.

- Maria Cristina Roque-Barreira conceived and designed the experiments, analyzed the data, authored or reviewed drafts of the paper, and approved the final draft.

\section{Data Availability}

The following information was supplied regarding data availability: The raw measurements are available in the Supplementary File.

\section{Supplemental Information}

Supplemental information for this article can be found online at http://dx.doi.org/10.7717/ peerj.10295\#supplemental-information.

\section{REFERENCES}

Arango Duque G, Descoteaux A. 2014. Macrophage cytokines: involvement in immunity and infectious diseases. Frontiers in Immunology 5:491 DOI 10.3389/fimmu.2014.00491.

Arora S, Olszewski MA, Tsang TM, McDonald RA, Toews GB, Huffnagle GB. 2011. Effect of cytokine interplay on macrophage polarization during chronic pulmonary infection with Cryptococcus neoformans. Infection and Immunity 79:1915-1926 DOI 10.1128/IAI.01270-10.

Bashir S, Sharma Y, Elahi A, Khan F. 2016. Macrophage polarization: the link between inflammation and related diseases. Inflammation Research 65:1-11 DOI 10.1007/s00011-015-0874-1.

Biondo C, Midiri A, Messina L, Tomasello F, Garufi G, Catania MR, Bombaci M, Beninati C, Teti G, Mancuso G. 2005. MyD88 and TLR2, but not TLR4, are required for host defense against Cryptococcus neoformans. European Journal of Immunology 35:870-878 DOI 10.1002/eji.200425799.

Butcher SK, O'Carroll CE, Wells CA, Carmody RJ. 2018. Toll-like receptors drive specific patterns of tolerance and training on restimulation of macrophages. Frontiers in Immunology 9:933 DOI 10.3389/fimmu.2018.00933.

Casadevall A, Pirofski LA. 2003. The damage-response framework of microbial pathogenesis. Nature Reviews. Microbiology 1:17-24 DOI 10.1038/nrmicro732.

Casadevall A, Pirofski LA. 2015. What is a host? Incorporating the microbiota into the damage-response framework. Infection and Immunity 83:2-7 DOI 10.1128/IAI.02627-14.

Chiapello LS, Baronetti JL, Garro AP, Spesso MF, Masih DT. 2008. Cryptococcus neoformans glucuronoxylomannan induces macrophage apoptosis mediated by nitric 
oxide in a caspase-independent pathway. International Immunology 20:1527-1541 DOI 10.1093/intimm/dxnl12.

Da Silva TA, Oliveira-Brito PKM, de Oliveira Thomaz SM, Roque-Barreira MC. 2020. ArtinM: purification and evaluation of biological activities. Methods in Molecular Biology 2132:349-358 DOI 10.1007/978-1-0716-0430-4_34.

Da Silva TA, Zorzetto-Fernandes ALV, Cecilio NT, Sardinha-Silva A, Fernandes FF, Roque-Barreira MC. 2017. CD14 is critical for TLR2-mediated M1 macrophage activation triggered by N-glycan recognition. Scientific Reports 7:7083 DOI 10.1038/s41598-017-07397-0.

Davis MJ, Tsang TM, Qiu Y, Dayrit JK, Freij JB, Huffnagle GB, Olszewski MA. 2013. Macrophage M1/M2 polarization dynamically adapts to changes in cytokine microenvironments in Cryptococcus neoformans infection. mBio 4:e00264-00213 DOI 10.1128/mBio.00264-13.

De Sousa JR, Da Costa Vasconcelos PF, Quaresma JAS. 2019. Functional aspects, phenotypic heterogeneity, and tissue immune response of macrophages in infectious diseases. Infection and Drug Resistance 12:2589-2611 DOI 10.2147/IDR.S208576.

Feng TT, Yang XY, Hao SS, Sun FF, Huang Y, Lin QS, Pan W. 2020. TLR-2-mediated metabolic reprogramming participates in polyene phosphatidylcholine-mediated inhibition of M1 macrophage polarization. Immunologic Research 68:28-38 DOI 10.1007/s12026-020-09125-9.

Fonseca FL, Nohara LL, Cordero RJ, Frases S, Casadevall A, Almeida IC, Nimrichter L, Rodrigues ML. 2010. Immunomodulatory effects of serotype B glucuronoxylomannan from Cryptococcus gattii correlate with polysaccharide diameter. Infection and Immunity 78:3861-3870 DOI 10.1128/IAI.00111-10.

Gordon S, Martinez FO. 2010. Alternative activation of macrophages: mechanism and functions. Immunity 32:593-604 DOI 10.1016/j.immuni.2010.05.007.

Johnston SA, May RC. 2013. Cryptococcus interactions with macrophages: evasion and manipulation of the phagosome by a fungal pathogen. Cellular Microbiology 15:403-411 DOI 10.1111/cmi.12067.

Klar AS, Michalak-Micka K, Biedermann T, Simmen-Meuli C, Reichmann E, Meuli M. 2018. Characterization of $\mathrm{M} 1$ and $\mathrm{M} 2$ polarization of macrophages in vascularized human dermo-epidermal skin substitutes in vivo. Pediatric Surgery International 34:129-135 DOI 10.1007/s00383-017-4179-z.

Kulsantiwong P, Pudla M, Srisaowakarn C, Boondit J, Utaisincharoen P. 2017. Pam2CSK4 and Pam3CSK4 induce iNOS expression via TBK1 and MyD88 molecules in mouse macrophage cell line RAW264.7. Inflammation Research 66:843-853 DOI 10.1007/s00011-017-1063-1.

Kumaresan PR, Da Silva TA, Kontoyiannis DP. 2017. Methods of controlling invasive fungal infections using CD8(+) T cells. Frontiers in Immunology 8:1939 DOI 10.3389/fimmu.2017.01939.

Mantovani A, Sica A, Sozzani S, Allavena P, Vecchi A, Locati M. 2004. The chemokine system in diverse forms of macrophage activation and polarization. Trends in Immunology 25:677-686 DOI 10.1016/j.it.2004.09.015. 
Montoya D, Mehta M, Ferguson BG, Teles RMB, Krutzik SR, Cruz D, Pellegrini M, Modlin RL. 2019. Plasticity of antimicrobial and phagocytic programs in human macrophages. Immunology 156:164-173 DOI 10.1111/imm.13013.

Murray PJ, Wynn TA. 2011. Protective and pathogenic functions of macrophage subsets. Nature Reviews Immunology 11:723-737 DOI 10.1038/nri3073.

Mylonas KJ, Nair MG, Prieto-Lafuente L, Paape D, Allen JE. 2009. Alternatively activated macrophages elicited by helminth infection can be reprogrammed to enable microbial killing. Journal of Immunology 182:3084-3094 DOI 10.4049/jimmunol.0803463.

Nakamura K, Miyagi K, Koguchi Y, Kinjo Y, Uezu K, Kinjo T, Akamine M, Fujita J, Kawamura I, Mitsuyama M, Adachi Y, Ohno N, Takeda K, Akira S, Miyazato A, Kaku M, Kawakami K. 2006. Limited contribution of Toll-like receptor 2 and 4 to the host response to a fungal infectious pathogen, Cryptococcus neoformans. FEMS Immunology and Medical Microbiology 47:148-154 DOI 10.1111/j.1574-695X.2006.00078.x.

Netea MG, Ferwerda G, Van der Graaf CA, Van der Meer JW, Kullberg BJ. 2006. Recognition of fungal pathogens by toll-like receptors. Current Pharmaceutical Design 12:4195-4201 DOI 10.2174/138161206778743538.

Ngamskulrungroj P, Chang Y, Sionov E, Kwon-Chung KJ. 2012. The primary target organ of Cryptococcus gattii is different from that of Cryptococcus neoformans in a murine model. mBio 3: DOI 10.1128/mBio.00103-12.

Oliveira-Brito PKM, Rezende CP, Almeida F, Roque-Barreira MC, Da Silva TA. 2020. iNOS/Arginase-1 expression in the pulmonary tissue over time during Cryptococcus gattii infection. Innate Immunity 26:117-129 DOI 10.1177/1753425919869436.

Pirofski LA, Casadevall A. 2017. Immune-mediated damage completes the parabola: cryptococcus neoformans pathogenesis can reflect the outcome of a weak or strong immune response. $m$ Bio 8: DOI 10.1128/mBio.02063-17.

Rath M, Muller I, Kropf P, Closs EI, Munder M. 2014. Metabolism via arginase or nitric oxide synthase: two competing arginine pathways in macrophages. Frontiers in Immunology 5:532 DOI 10.3389/fimmu.2014.00532.

Schlaepfer E, Rochat MA, Duo L, Speck RF. 2014. Triggering TLR2, -3, -4, -5, and 8 reinforces the restrictive nature of M1- and M2-polarized macrophages to HIV. Journal of Virology 88:9769-9781 DOI 10.1128/JVI.01053-14.

Schoffelen T, Illnait-Zaragozi MT, Joosten LA, Netea MG, Boekhout T, Meis JF, Sprong T. 2013. Cryptococcus gattii induces a cytokine pattern that is distinct from other cryptococcal species. PLOS ONE 8:e55579 DOI 10.1371/journal.pone.0055579.

Shapouri-Moghaddam A, Mohammadian S, Vazini H, Taghadosi M, Esmaeili SA, Mardani F, Seifi B, Mohammadi A, Afshari JT, Sahebkar A. 2018. Macrophage plasticity, polarization, and function in health and disease. Journal of Cellular Physiology 233:6425-6440 DOI 10.1002/jcp.26429.

Sica A, Mantovani A. 2012. Macrophage plasticity and polarization: in vivo veritas. Journal of Clinical Investigation 122:787-795 DOI 10.1172/JCI59643. 
Peer

Soares MP, Teixeira L, Moita LF. 2017. Disease tolerance and immunity in host protection against infection. Nature Reviews Immunology 17:83-96 DOI 10.1038/nri.2016.136. Stout RD, Jiang C, Matta B, Tietzel I, Watkins SK, Suttles J. 2005. Macrophages sequentially change their functional phenotype in response to changes in microenvironmental influences. Journal of Immunology 175:342-349 DOI 10.4049/jimmunol.175.1.342.

Taghavi M, Khosravi A, Mortaz E, Nikaein D, Athari SS. 2017. Role of pathogenassociated molecular patterns (PAMPS) in immune responses to fungal infections. European Journal of Pharmacology 808:8-13 DOI 10.1016/j.ejphar.2016.11.013.

Ueno K, Otani Y, Yanagihara N, Nakamura T, Shimizu K, Yamagoe S, Miyazaki Y. 2019. Cryptococcus gattii alters immunostimulatory potential in response to the environment. PLoS One 14:e220989 DOI 10.1371/journal.pone.0220989.

Wang J, Li R, Peng Z, Hu B, Rao X, Li J. 2020. HMGB1 participates in LPSinduced acute lung injury by activating the AIM2 inflammasome in macrophages and inducing polarization of M1 macrophages via TLR2, TLR4, and RAGE/NFkappaB signaling pathways. International Journal of Molecular Medicine 45:61-80 DOI 10.3892/ijmm.2019.4402.

Wang N, Liang H, Zen K. 2014. Molecular mechanisms that influence the macrophage m1-m2 polarization balance. Frontiers in Immunology 5:614 DOI 10.3389/fimmu.2014.00614

Yauch LE, Mansour MK, Shoham S, Rottman JB, Levitz SM. 2004. Involvement of CD14, toll-like receptors 2 and 4, and MyD88 in the host response to the fungal pathogen Cryptococcus neoformans in vivo. Infection and Immunity 72:5373-5382 DOI 10.1128/IAI.72.9.5373-5382.2004.

Zhu Y, Zhang L, Lu Q, Gao Y, Cai Y, Sui A, Su T, Shen X, Xie B. 2017. Identification of different macrophage subpopulations with distinct activities in a mouse model of oxygen-induced retinopathy. International Journal of Molecular Medicine 40:281-292 DOI 10.3892/ijmm.2017.3022. 


\author{
Author Queries \\ Journal: $\quad$ PEERJ \\ Article id: $\quad 10295$ \\ Author: de Campos et al. \\ Title: $\quad$ Pro-inflammatory response ensured by LPS and Pam3CSK4 in RAW 264.7 cells did not improve a \\ fungistatic effect on Cryptococcus gattii infection
}

Q1 (Page 1)

Please check all author names, initials, and affiliations to confirm they are accurate.

Q2 (Page 16)

Arango Duque \& Descoteaux (2014), Butcher et al. (2018), Kumaresan et al. (2017), Rath et al. (2014), Wang et al. (2014) appear with one page number instead of a page range. If these are not single page references, please provide the page ranges. If the journal only uses article numbers for citations instead of page ranges, please provide that article number. If any of these are abstracts, please confirm which are single page abstracts and we will insert "[Abstract]" in the reference(s). 
ANEXOS 


\section{Anexo I}

Certificado de aprovação da Comissão de Ética no Uso de Animais da Faculdade de Medicina de Ribeirão Preto da Universidade de São Paulo 

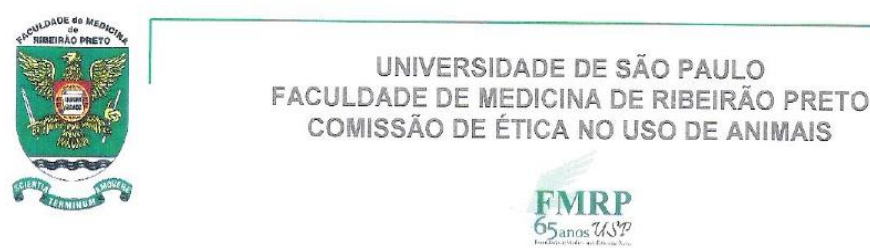

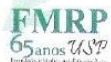

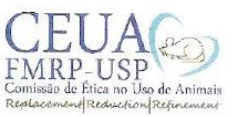

\section{$C E R T I F I C A D O$}

Certificamos que o Protocolo intitulado "Agonistas de TLR2 como adjurantes em uma estratégia de vacinação contra a criplococose experimental", registrado com o número 072/2019, sob a responsabilidade da Profa. Dra. Maria Cristina Roque Antunes Barreira, envolvendo a produção, manutenção ou utilização de animais pertencentes ao filo Chordata, subfilo Vertebrata (exceto humanos) para fins de pesquisa cientifica, encontra-se de acordo com os preceitos da Lei $n^{\circ} 11.794$ de 8 de outubro de 2008, do Decreto $\mathrm{n}^{\circ} 6.899$ de 15 de julho de 2009 e com as normas editadas pelo Conselho Nacional de Controle de Experimentação Animal (CONCEA), e foi APROVADO pela Comissão de Ética no Uso de Animais da Faculdade de Medicina de Ribeirão Preto da Universidade de São Paulo, em reunião de 29 de julho de 2019.

Este Protocolo prevê a utilização de 90 camundongos Balb c machos pesando $21 \mathrm{~g}$ oriundos do Serviço de Biotério da Faculdade de Medicina de Ribeirão Preto da Universidade de São Paulo Vigência da autorização: 29/07/2019 a 31/07/2021.

We certify that the Protocol $n^{\circ} 072 / 2019$, entitled "TLR2 agonists as adjuvants in vaccination strategy against experimental cryptococcosis", is in accordance with the Ethical Principles in Animal Research adopted by the National Council for the Control of Animal Experimentation (CONCEA) and was approved by the Local Animal Ethical Committee from Ribeirão Preto Medical School of the University of São Paulo in 07/29/2019. This protocol involves the production, maintenance or use of animals from phylum Chordata, subphylum Vertebrata (except humans) for research purposes, and includes the use of 90 male Balb c mice weighing $2 \mathrm{lg}$ from the Central Animal House of Ribeirão Preto Medical School, University of São Paulo. This certificate is valid until 07/31/2021.

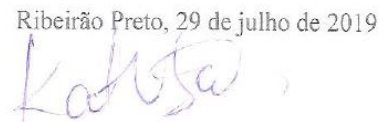

Profa. Dra. KatiuchiaUzzun Sales Coordenadora da CEUA-FMRP - USP 